\title{
Transportable Heavy Duty Emissions Testing Laboratory and Research Program
}

Prepared for

The U.S. Department of Energy (DOE)

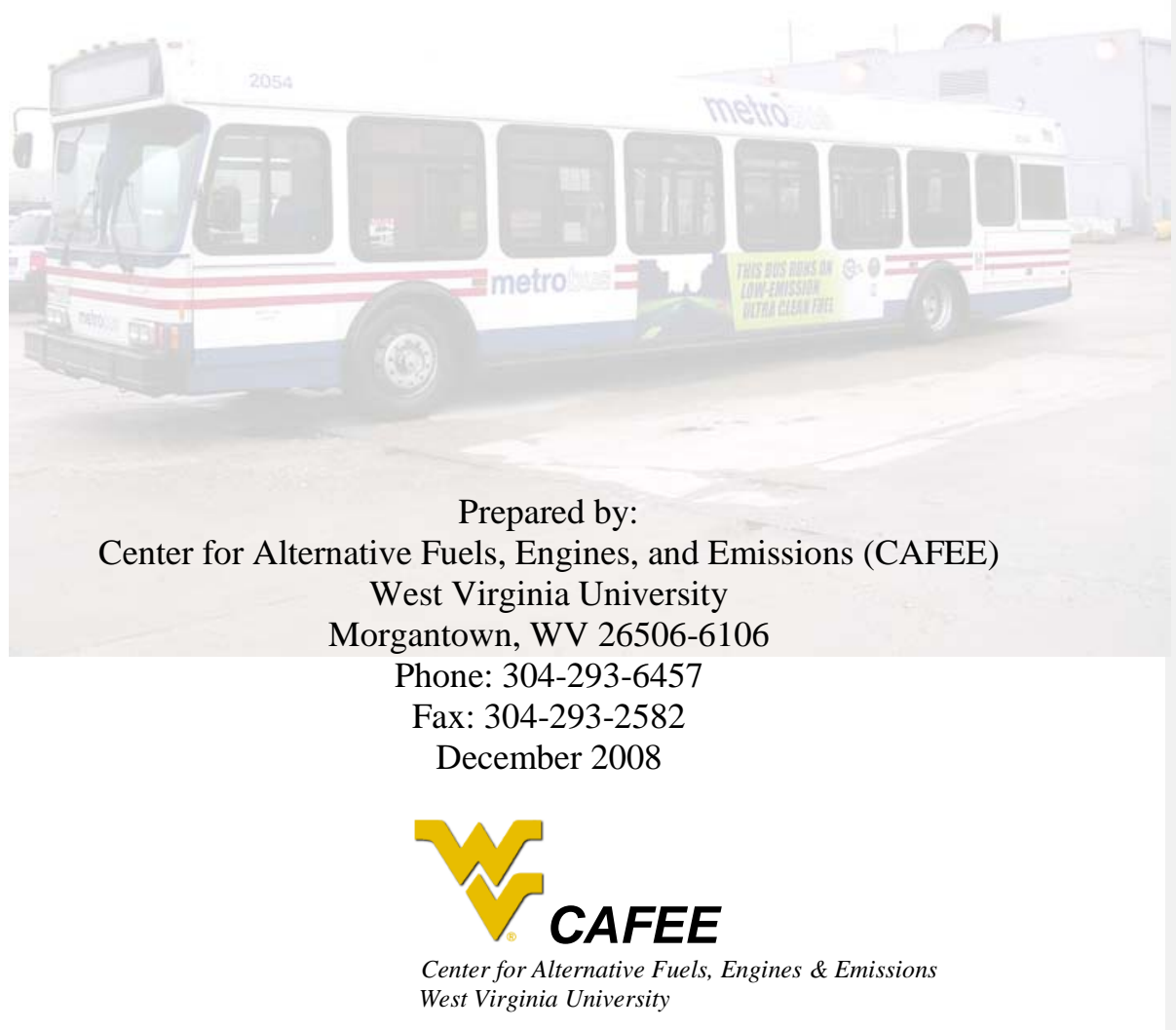




\section{DISCLAIMER}

This report was prepared as an account of work sponsored by an agency of the United States Government. Neither the United States Government nor any agency thereof, nor any of their employees, makes any warranty, express or implied, or assumes any legal liability or responsibility for the accuracy, completeness, or usefulness of any information, apparatus, product, or process disclosed, or represents that its use would not infringe privately owned rights. Reference herein to any specific commercial product, process, or service by trade name, trademark, manufacturer, or otherwise does not necessarily constitute or imply its endorsement, recommendation, or favoring by the United States Government or any agency thereof. The views and opinions of authors expressed herein do not necessarily state or reflect those of the United States Government or any agency thereof. 


\section{Transportable Heavy Duty Emissions Testing Laboratory and Research Program}

Donald W. Lyons, Principal Investigator Center for Alternative Fuels, Engines, and Emissions (CAFEE)

Department of Mechanical \& Aerospace Engineering West Virginia University

Morgantown, WV 26506-6106

Phone: 304-293-6457

Fax: 304-293-2582

December 30, 2008

Prepared under Task No. DE-FG26-90CH10451, the U.S. Department of Energy

\section{DISCLAIMER}

This report is submitted by the Center for Alternative Fuels, Engines, and Emissions (CAFEE). The opinions and conclusions expressed or implied in the report are those of the researchers. They are not necessarily those of the U.S. Department of Energy (DOE). 


\section{TABLE OF CONTENTS}

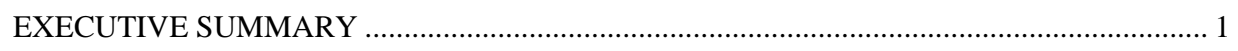

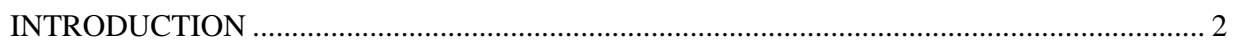

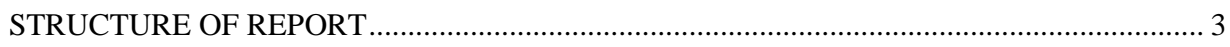

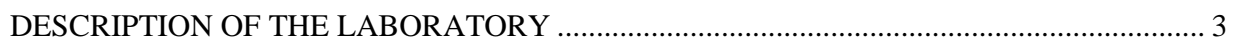

DESCRIPTION OF THE WVU CHASSIS DYNAMOMETER ................................................ 3

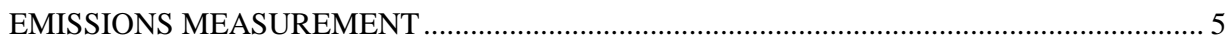

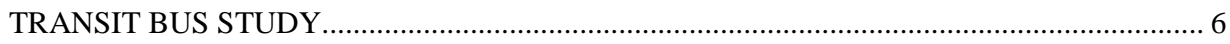

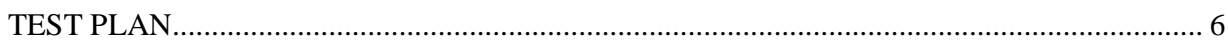

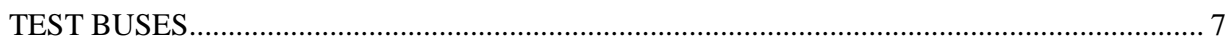

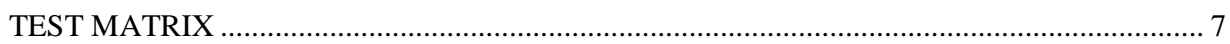

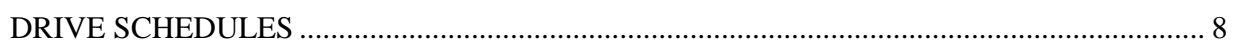

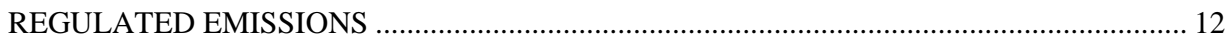

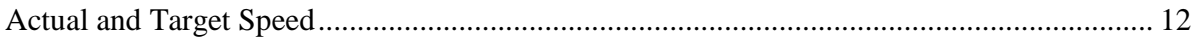

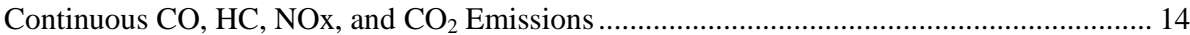

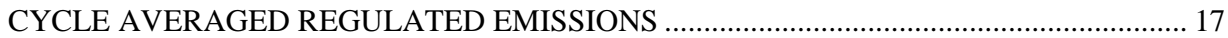

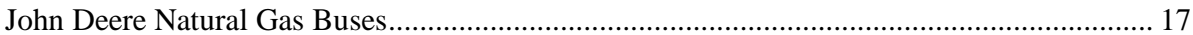

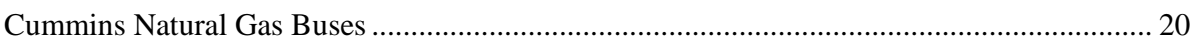

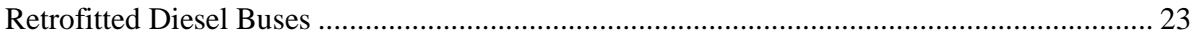

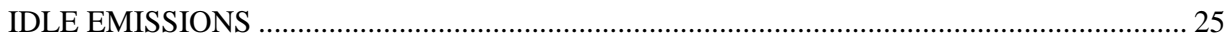

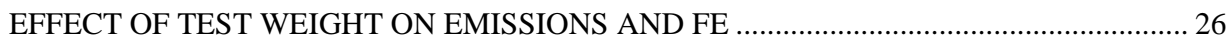

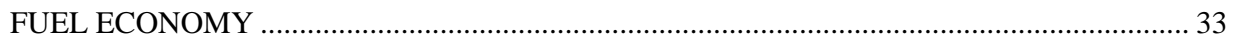

METHANE AND NON-METHANE HYDROCARBONS (NMHC) EMISSIONS .................. 35

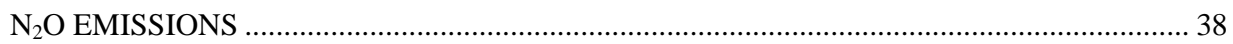

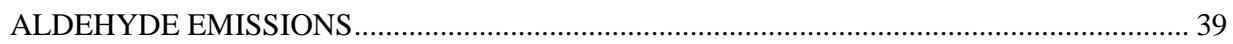

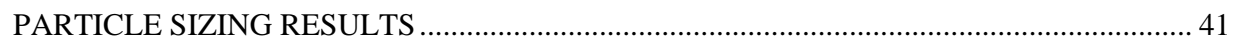

OTHER TRANSPORTABLE LABORATORY STUDIES.......................................................... 45

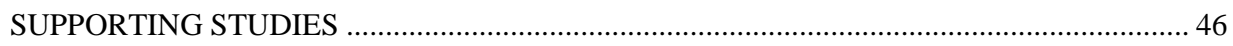

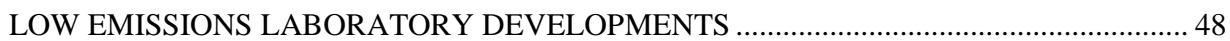




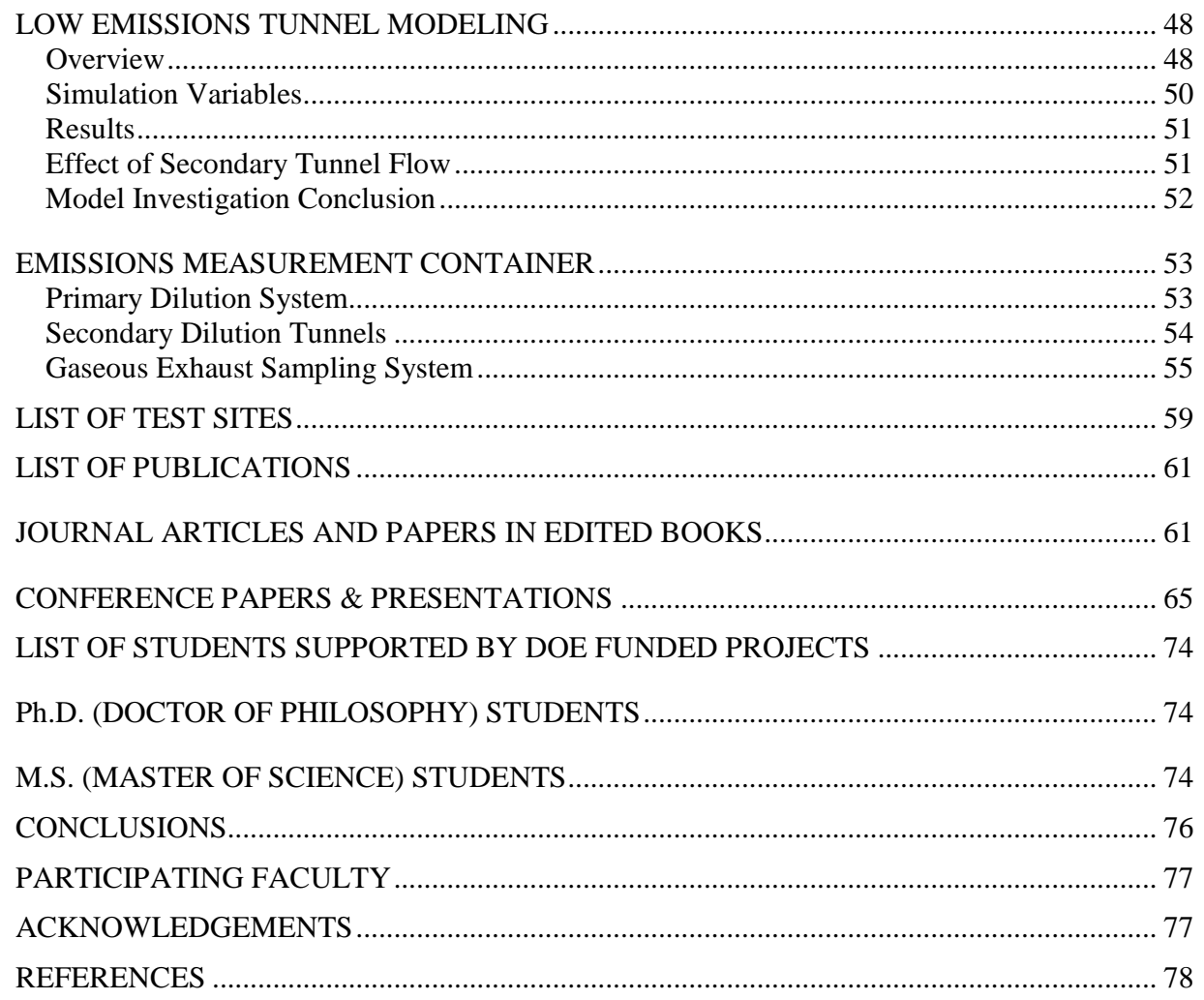




\section{LIST OF FIGURES}

Figure 1: View of a John Deere natural gas bus installed on the dynamometer............................ 4

Figure 2: Hub adapters connect vehicle’s drive axle directly to the power absorber unit.............. 5

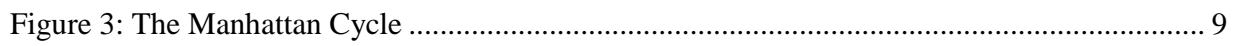

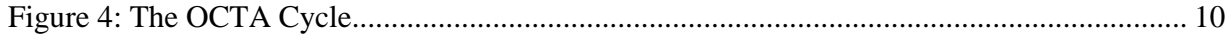

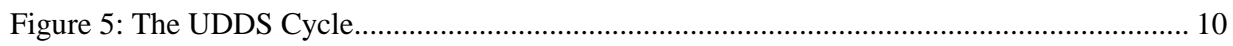

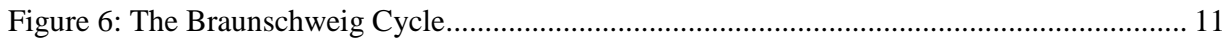

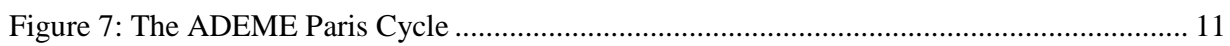

Figure 8: Comparison of the actual and target speed from the third John Deere bus on the

Braunschweig Cycle

Figure 9: Comparison of the actual and target speed the third Cummins bus on the Braunschweig

Cycle 13

Figure 10: Comparison of the actual and target speed from the second diesel bus on the Braunschweig Cycle

Figure 11: Continuous CO emissions from the third John Deere bus on the Braunschweig Cycle.

Clearly the CO level is at the detection level of the analyzer..................................................... 14

Figure 12: Continuous HC emissions from the third John Deere bus on the Braunschweig Cycle

Figure 13: Continuous NOx emissions from the third John Deere bus on the Braunschweig Cycle 15

Figure 14: Continuous $\mathrm{CO}_{2}$ emissions from the third John Deere bus on the Braunschweig Cycle 16

Figure 15: Continuous NOx emissions from the third Cummins bus on the Braunschweig Cycle

Figure 16: Continuous NOx emissions from the second diesel bus on the Braunschweig Cycle 17 Figure 17: Cycle averaged CO emissions (bag data) from John Deere natural gas buses (g/mile). The $\mathrm{X}$-axis shows the cycles used (Table 2 ) and the bus number (Table 1). ................................ 18

Figure 18: Cycle averaged HC emissions from John Deere natural gas buses (g/mile)............... 19

Figure 19: Cycle averaged NOx emissions from John Deere natural gas buses (g/mile)............. 19

Figure 20: Cycle averaged PM emissions from John Deere natural gas buses (g/mile).............. 20 
Figure 21: Cycle averaged CO emissions from Cummins natural gas buses (g/mile)

Figure 22: Cycle averaged HC emissions from Cummins natural gas buses (g/mile) ................. 21

Figure 23: Cycle averaged NOx emissions from Cummins natural gas buses (g/mile) ............... 22

Figure 24: Cycle averaged PM emissions from Cummins natural gas buses (g/mile) ................. 22

Figure 25: Cycle averaged CO emissions from retrofitted diesel buses (g/mile). The values of CO that were zero or negative were considered to be below the detectable limit and are shown as a

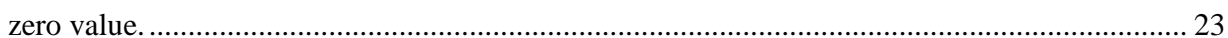

Figure 26: Cycle averaged HC emissions from retrofitted diesel buses (g/mile) ......................... 24

Figure 27: Cycle averaged NOx emissions from retrofitted diesel buses (g/mile)...................... 24

Figure 28: Cycle averaged PM emissions from retrofitted diesel buses (g/mile)........................ 25

Figure 29: Comparison of idle emissions from the John Deere and Cummins natural gas buses and the retrofitted diesel bus. Note that $\mathrm{CO}$ and PM scales are increased a 100 fold while $\mathrm{CO}_{2}$ scale was decreased a 100 fold.

Figure 30: Weight effect on the third John Deere bus on the OCTA Cycle. Note that CO and PM scales were increased a 100 fold while $\mathrm{CO}_{2}$ scale was decreased a 100 fold............................... 28

Figure 31: Weight effect on the third John Deere bus on the Paris Cycle..................................... 28

Figure 32: Weight effect on the third John Deere bus on the Braunschweig Cycle..................... 29

Figure 33: Weight effect on the third Cummins bus on the OCTA Cycle. Note that CO and PM scales were increased a 100 fold while $\mathrm{CO}_{2}$ scale was decreased a 100 fold......................... 30

Figure 34: Weight effect on the third Cummins bus on the Paris Cycle ..................................... 30

Figure 35: Weight effect on the third Cummins bus on the Braunschweig Cycle ...................... 31

Figure 36: Weight effect on the second diesel bus on the OCTA Cycle. Note that CO and PM scales were increased a 100 fold while $\mathrm{CO}_{2}$ scale was decreased a 100 fold............................... 32

Figure 37: Weight effect on the second diesel bus on the Paris Cycle .......................................... 32

Figure 38: Weight effect on the second diesel bus on the Braunschweig Cycle ......................... 33

Figure 39: Cycle averaged FE from John Deere natural gas buses (mile/gal)............................. 34

Figure 40: Cycle averaged FE from Cummins natural gas buses (mile/gal) .............................. 34

Figure 41: Cycle averaged FE from retrofitted diesel buses (mile/gal) ....................................... 35

Figure 42: Cycle averaged Methane emissions from John Deere natural gas buses .................... 36

Figure 43: Cycle averaged NMHC emissions from John Deere natural gas buses ....................... 37

Figure 44: Cycle averaged Methane emissions from Cummins natural gas buses....................... 37 
Figure 45: Cycle averaged NMHC emissions from Cummins natural gas buses

Figure 46: Average distance-specific $\mathrm{N}_{2} \mathrm{O}$ emissions from John Deere and Cummins natural gas buses and retrofitted diesel bus.

Figure 47: Background corrected formaldehyde, acetone, and acetaldehyde emissions from John Deere and Cummins natural gas buses and retrofitted diesel bus on three test cycles each tested at no-load

Figure 48: Background corrected formaldehyde, acetone, and acetaldehyde emissions from John Deere and Cummins natural gas buses and retrofitted diesel bus on three test cycles each tested at full-load

Figure 49: Total particle number concentrations for the third John Deere bus with three different test weights through the OCTA Cycle.

Figure 50: Average size distributions and number concentrations on the OCTA Cycle for the third John Deere bus with three different test weights

Figure 51: Total number of particles per cycle with test weight ................................................. 44

Figure 52: Simulink ${ }^{\circledR}$ Model of PM Sampling System-Highest Level ..................................... 49

Figure 53: Sub-Level View of $2^{\text {nd }}$ tunnel and PM filter ........................................................... 49

Figure 54: Maximum and minimum filter face temperatures with different secondary tunnel flow rates

Figure 55: Inline subsonic venturi discharge coefficient vs. Reynolds number calibration curve 54

Figure 56: 2007 PM sampling system heated enclosure.......................................................... 55

Figure 57: Schematic of laboratory emission test tunnels of the Translab ................................. 56

Figure 58: Side view of the Translab emissions measurement system......................................... 56

Figure 59: Inside view of the Translab emissions measurement system .................................... 57

Figure 60: View of the diesel tunnel sample zone...................................................................... 57

Figure 61: Rear view of the Translab emissions measurement system .................................... 58

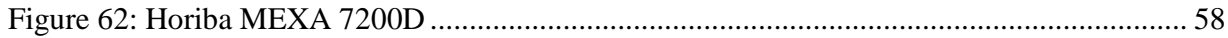




\section{LIST OF TABLES}

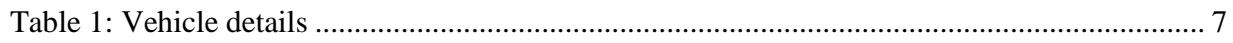

Table 2: Properties of drive cycles, in order of ascending average speed ..................................... 9

Table 3: Load specification for no load, half load, and full load testing ..................................... 26

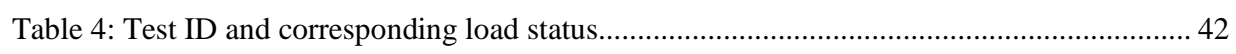

Table 5: List of test sites with total number of tests .................................................................. 59 


\section{EXECUTIVE SUMMARY}

The objective of this program was to quantify the emissions from heavy-duty vehicles operating on alternative fuels or advanced fuel blends, often with novel engine technology or aftertreatment. In the first year of the program West Virginia University (WVU) researchers determined that a transportable chassis dynamometer emissions measurement approach was required so that fleets of trucks and buses did not need to be ferried across the nation to a fixed facility. A Transportable Heavy-Duty Vehicle Emissions Testing Laboratory (Translab) was designed, constructed and verified. This laboratory consisted of a chassis dynamometer semi-trailer and an analytic trailer housing a full scale exhaust dilution tunnel and sampling system which mimicked closely the system described in the Code of Federal Regulations for engine certification. The Translab was first used to quantify emissions from natural gas and methanol fueled transit buses, and a second Translab unit was constructed to satisfy research demand. Subsequent emissions measurement was performed on trucks and buses using ethanol, Fischer-Tropsch fuel, and biodiesel. A medium-duty chassis dynamometer was also designed and constructed to facilitate research on delivery vehicles in the 10,000 to $20,000 \mathrm{lb}$ range. The Translab participated in major programs to evaluate low-sulfur diesel in conjunction with passively regenerating exhaust particulate filtration technology, and substantial reductions in particulate matter were recorded. The researchers also participated in programs to evaluate emissions from advanced natural gas engines with closed loop feedback control. These natural gas engines showed substantially reduced levels of oxides of nitrogen. For all of the trucks and buses characterized, the levels of carbon monoxide, oxides of nitrogen, hydrocarbons, carbon dioxide and particulate matter were quantified, and in many cases non-regulated species such as aldehydes were also sampled. Particle size was also quantified during selected studies. A laboratory was established at WVU to provide for studies which supported and augmented the Translab research, and to provide for development of superior emissions measurement systems. This laboratory research focused on engine control and fuel sulfur issues. In recent years, as engine and aftertreatment technologies advanced, emissions levels were reduced such that that they were at or below the Translab detectable limits, and in the same time frame the US Environmental Protection Agency required improved measurement methodologies for engine emissions certification. To remain current and relevant, the researchers designed a new Translab analytic system, housed in a container which can be transported on a semi-trailer. The new system's dilution tunnel flow was designed to use a subsonic venturi with closed loop control of blower speed, and the secondary dilution and particulate matter filter capture were designed to follow new EPA engine certification procedures. A further contribution of the program has been the development of techniques for creating heavy-duty vehicle test schedules, and the creation of schedules to mimic a variety of truck and bus vocations. 


\section{INTRODUCTION}

The objective of this program was to quantify the emissions from heavy-duty vehicles operating on alternative fuels or advanced fuel blends. At the beginning of the program, few quantitative measurements of heavy-duty vehicle emissions were reported in the literature. West Virginia University (WVU) researchers examined options for quantifying emissions of trucks and buses in revenue service, and evaluated merits of on-board measurement, engine removal with test cell use, and chassis dynamometer use. The chassis dynamometer approach best satisfied convenience and accuracy criteria, but it was recognized that many vehicle owners could not part with a vehicle for sufficient time to allow its transportation to and from a central location. To solve this problem, the researchers designed, constructed and verified the first known Transportable Heavy-Duty Vehicle Emissions Testing Laboratory (Translab) which consisted of a chassis dynamometer semi-trailer, an analytic trailer housing a full scale exhaust dilution tunnel and sampling system, dray vehicles and support equipment. The Translab was capable of being transported to an advanced vehicle technology fleet location by road, and to characterize emissions from trucks and buses on site. The Translab was first deployed in 1992, and was first used to examine natural gas and methanol fueled transit buses. Sufficient demand for field emissions characterization led to the construction of a second Translab unit, and an additional chassis dynamometer sized for medium-duty vehicles. In addition, a laboratory was established at WVU to provide for supporting studies. These studies advanced and examined technologies related to alternative fuels and vehicle emissions reduction, provided support for the Translab research, and piloted emissions measurement techniques. Also, the program included modeling and development in support of the Translab and to interpret Translab data. The most visible input was the development of methodologies to create representative truck and bus test schedules, and the creation of schedules themselves based on measured vehicle activity. The program examined the emissions benefits of methanol and ethanol (in compression ignition applications), biodiesel, compressed natural gas (CNG), liquefied natural gas (LNG), Fischer-Tropsch (F-T) fuels and advanced low-sulfur petroleum diesel formulations. As some alternative fuel and aftertreatment technologies advanced, emissions levels dropped to the point that they were at or below the Translab detectable limits. In addition, the US Environmental Protection Agency (EPA) required improved methodologies for emissions measurement from 2007 onward. To remain current and relevant, the researchers designed a new analytic system, housed in a container which can be transported on a semi-trailer. The new system's dilution tunnel flow was managed by a subsonic venturi with closed loop control of blower speed, and the secondary dilution and particulate matter filter capture were compliant with new EPA engine certification procedures.

It is not possible within the scope of this report to provide details of all the research performed over an eighteen year period, but an example of a Translab emissions characterization campaign has been presented in detail, with summaries of activities at other selected sites. Also, support studies have been summarized. Detail is also provided on the design of the low-emissions container system. 


\section{STRUCTURE OF REPORT}

The program described in this report covers an extended research period, but is centered around the issue of heavy-duty vehicle emissions measurement, primarily through the operation of trucks and buses on the Transportable Laboratory (Translab), which incorporates a chassis dynamometer. The Translab is described in the next section, in the configuration that was used for the last reported field study. This configuration evolved slightly from the original design, but the description is sufficient for use in understanding all of the studies reported below.

A transit bus study, on diesel and natural gas buses, is presented as a major section below. This serves to illustrate the methods used in the Translab studies, and also covers aspects of data processing and data interpretation. This section also highlights the effect of test weight and test schedule on the resulting emissions measurements and provides details of advanced bus technologies in recent use.

Additional Translab studies have each been summarized separately, providing information on the purpose of the measurements, the vehicles that were characterized, the test conditions, and the project conclusions.

This report also covers supporting studies that did not directly involve chassis dynamometer testing, but which were oriented to engine emissions characterization. Each of these studies is summarized, with information on purpose, approach and results. Most noteworthy of these studies was the research that supported the Diesel Emissions Control Sulfur Effect (DECSE) program that assessed the need for ultra-low sulfur fuel for diesel engine aftertreatment systems.

\section{DESCRIPTION OF THE LABORATORY}

Emissions from buses and trucks were characterized with WVU Translab. The Translab consisted of a chassis dynamometer, an emissions analyzer trailer, and a mobile workshop to support them. It was designed to conduct emissions characterization in accordance with the provisions prescribed by the United States Code of Federal Regulations (CFR) Title 40, Subpart B \& N of Part 86 [1] as far as possible for work in the field. Detailed description of the Translab can be found in technical papers by Clark et al. [2], Lyons et al. [3], and Gautam et al. [4].

\section{DESCRIPTION OF THE WVU CHASSIS DYNAMOMETER}

Operation of the laboratory is described in terms of transit bus emissions characterization. For emissions collection, a bus was positioned on the chassis dynamometer as shown in | Figure 1Figure 1. Its drive wheels were placed on two sets of rollers, which were 12.6 
inches in diameter. Axle power from the vehicle was taken directly to the dynamometer units by replacing the rear outer wheels with a hub adapter on each side of the vehicle | connected to the dynamometer through drive shafts, as shown in Figure 2Figure 2. Each dynamometer unit consisted of a flywheel assembly, an eddy current power absorber, and a torque transducer. Flywheel sets consisted of a series of discs that allowed simulation of inertial load. During the testing of the bus, torque cells and speed transducers measured the vehicle load while the power absorbers were used to mimic tire losses and wind drag. A human driver drove the vehicle following the speed-time trace presented on a monitor and placed inside the driver cabin. In this research, the vehicle losses were set using a coast down on the dynamometer. The coast down curve was created using the road load equation. The drag coefficient was set at 0.79 , and the tire rolling resistance coefficient was set to 0.008 based on on-road coast downs performed during recent WVU bus research [5]. Previous research used a default rolling resistance coefficient of 0.00938 , which is a value presented in the CFR.

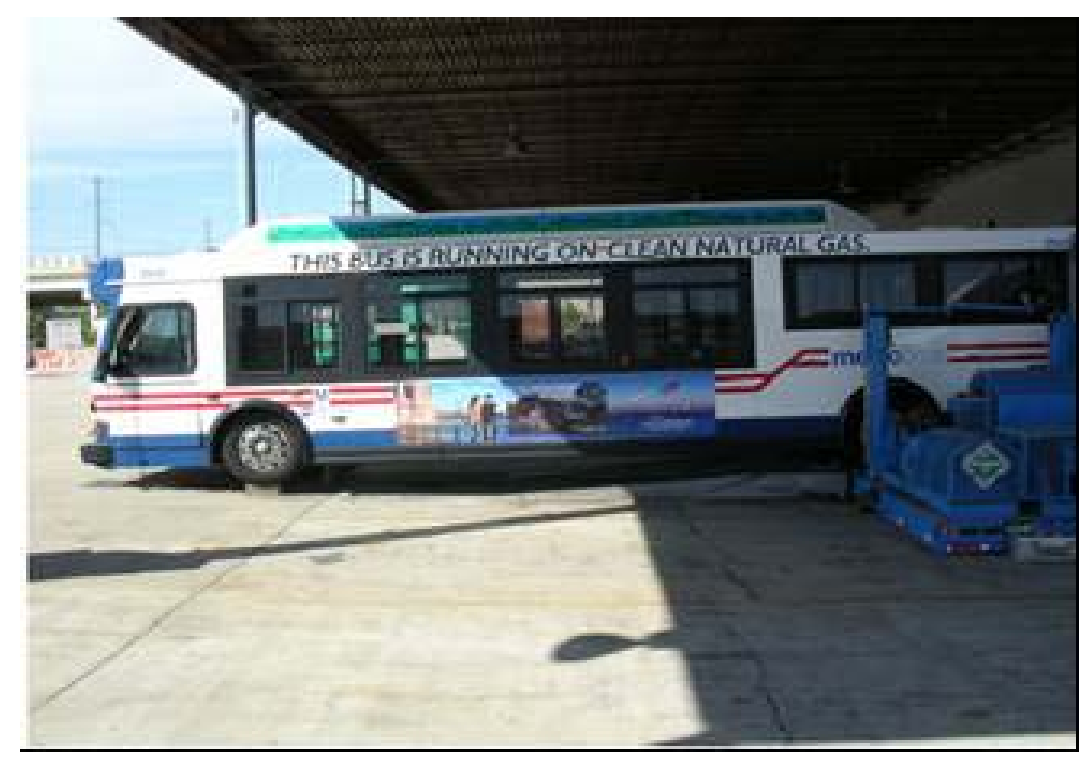

Figure 1: View of a John Deere natural gas bus installed on the dynamometer 


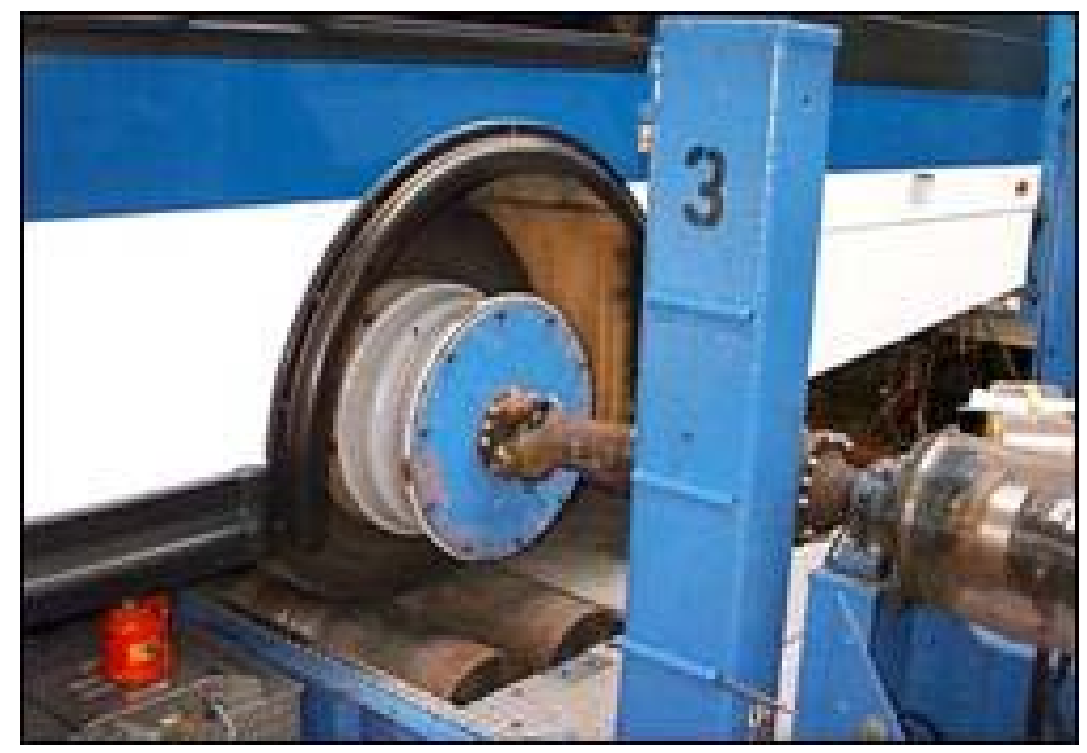

Figure 2: Hub adapters connect vehicle's drive axle directly to the power absorber unit

\section{EMISSIONS MEASUREMENT}

Exhaust from the vehicle's tailpipe was ducted to a full-scale dilution tunnel. The tunnel was 18 inches in diameter and 20 feet in length. HEPA filtered ambient air was mixed with the exhaust in the primary dilution tunnel in order to ensure that PM sample filter temperature was below $125^{\circ} \mathrm{F}$ for PM sampling. Heated lines were used to convey the samples from the dilution tunnel to research grade analyzers. All data were corrected for background levels in the dilution air. Both $\mathrm{CO}$ and $\mathrm{CO}_{2}$ were measured using nondispersive infrared analyzers (NDIR). CO data may be processed using either integration of continuous data or concentrations from a Tedler bag of dilute exhaust gas, collected over the duration of the cycle. Bag CO data have been used to prepare data shown in this section of the report. Samples were passed through a refrigerator/dryer before they reached the analyzers. NOx was measured using a wet chemiluminescent analyzer while HC was measured using the heated flame ionization detection (HFID) method. The HC probe and line were maintained at $375^{\circ} \mathrm{F}$ while all other lines were maintained at $250^{\circ} \mathrm{F}$ to prevent condensation of moisture in the system. PM samples were taken through three sets of parallel filters located after the secondary dilution tunnel, which was attached to the primary dilution tunnel. The PM samples were collected gravimetrically in one 70 $\mathrm{mm}$ and two $47 \mathrm{~mm}$ fluorocarbon coated glass-fiber filter holders, each holding two filters in series. PM weights from the $70 \mathrm{~mm}$ filers are used in this section. These filters were conditioned before and after each test and weighed in the climate controlled 
enclosure at WVU using a Sartorius SR2A micro balance to determine the gravimetric mass accumulated during the test.

\section{TRANSIT BUS STUDY}

The study reported in this section is typical of the field studies performed under this program. Detail is provided for this particular study, and the remaining field studies are summarized later in the report. The investigators measured exhaust emissions and fuel consumption data from transit buses fueled with diesel and compressed natural gas (CNG). A total of eight buses representing conventional diesel and CNG were tested with varying weights and aftertreatment configurations. The test matrices involved three CNG buses powered by John Deere RG6081 lean-burn natural gas engines, three CNG buses powered by Cummins CG-280 closed loop lean-burn natural gas engines, and two 1992 model year Orion diesel buses retrofitted with Detroit Diesel Corporation (DDC) 2003 model year Series 50, 275 horsepower (hp) engines.

The program yielded data which also supported an International Energy Agency (IEA) program to compare transit bus technologies across the Atlantic. The main objective of the IEA program was to compare a number of duty cycles across North America and Europe in order to "generate understanding of the characteristics of different duty cycles, to produce a key for cross-interpretation of emission results generated with different cycles, to study the interaction between vehicle, exhaust after-treatment and fuel technologies and test procedures, and to pin-point the need for international harmonization in emission testing" [6]. The project involved testing of baseline and advanced diesel buses, stoichiometric and lean-burn natural gas buses, and diesel hybridelectric buses. Other bus data in the IEA program were supplied by VTT Technical Research Center of Finland and Environment Canada.

The Translab was used to characterize emissions from these buses at the Washington Metro Area Transit Authority (WMATA) test site in Landover, Maryland. Carbon monoxide (CO), hydrocarbons (HC), oxides of nitrogen (NOx), carbon dioxide $\left(\mathrm{CO}_{2}\right)$, and particulates (PM) from these buses were collected using the Translab. HC emissions from the natural gas buses were speciated into methane $\left(\mathrm{CH}_{4}\right)$ and non-methane hydrocarbons (NMHC). $\mathrm{CO}_{2}$ data were inferred to calculate fuel economy (FE) in miles per diesel equivalent gallon (mile/gal). PM emissions were measured using 70 millimeters (mm) fluorocarbon coated glass-fiber filters and two $47 \mathrm{~mm}$ prototype sampling trains were also employed. Emissions of non-regulated species such as aldehyde using DNPH cartridges and nitrous oxide $\left(\mathrm{N}_{2} \mathrm{O}\right)$ were also collected from one bus of each of the three technologies.

\section{TEST PLAN}

Testing of these buses was conducted from May 2006 to August 2006. A comprehensive test plan was prepared before the WVU Translab was moved to WMATA. This plan 
described the test procedures and data collection in detail including the vehicle information, drive cycle characteristics, fuel specifications, laboratory calibration, vehicle inspection and preparation, and emissions testing methodology.

\section{TEST BUSES}

Salient information on the transit buses is provided in Table 1. Curb weights of the buses were determined using a portable scale.

Table 1: Vehicle details

\begin{tabular}{|c|c|c|c|c|c|c|c|}
\hline Bus ID & $\begin{array}{l}\text { WMATA } \\
\text { Bus No. }\end{array}$ & $\begin{array}{l}\text { Bus } \\
\text { Type } \\
\text { \& MY }\end{array}$ & $\begin{array}{l}\text { Engine Type } \\
\text { \& MY }\end{array}$ & $\begin{array}{l}\text { GVW } \\
\text { in } \\
\text { pounds } \\
\text { (lb) }\end{array}$ & $\begin{array}{l}\text { After- } \\
\text { treatment }\end{array}$ & $\begin{array}{l}\text { Curb } \\
\text { Wt. } \\
\text { (lb) }\end{array}$ & $\begin{array}{l}\text { Odometer } \\
\text { Mileage }\end{array}$ \\
\hline $\begin{array}{l}\text { John Deere } \\
\# 1\end{array}$ & 2639 & \multirow[t]{3}{*}{$\begin{array}{l}\text { Orion } \\
2005\end{array}$} & \multirow[t]{3}{*}{$\begin{array}{l}\text { RG6081 } \\
280 \text { hp, } 2005\end{array}$} & \multirow[t]{3}{*}{42540} & \multirow[t]{3}{*}{$\begin{array}{l}\text { Catalytic } \\
\text { Converters }\end{array}$} & 32050 & 4225 \\
\hline $\begin{array}{l}\text { John Deere } \\
\# 2\end{array}$ & 2621 & & & & & 31660 & 3148 \\
\hline $\begin{array}{l}\text { John Deere } \\
\# 3\end{array}$ & 2640 & & & & & 32320 & 7717 \\
\hline Cummins\#1 & 2501 & \multirow[t]{3}{*}{$\begin{array}{l}\text { Orion } \\
2005\end{array}$} & $\begin{array}{l}\text { Cummins } \\
\text { CG- } 280 \text { hp, } 2004\end{array}$ & \multirow[t]{3}{*}{42540} & \multirow[t]{3}{*}{$\begin{array}{l}\text { Catalytic } \\
\text { Converters }\end{array}$} & 32160 & 18593 \\
\hline Cummins\#2 & 2502 & & \multirow{2}{*}{$\begin{array}{l}\text { Cummins } \\
\text { CG- } 280 \text { hp, } 2005\end{array}$} & & & 32560 & 26858 \\
\hline Cummins\#3 & 2503 & & & & & 32300 & 4719 \\
\hline Diesel\#1 & 9643 & \multirow[t]{2}{*}{$\begin{array}{l}\text { Orion } \\
1992\end{array}$} & \multirow[t]{2}{*}{$\begin{array}{l}\text { DDC S50 } \\
275 \mathrm{hp} \\
2003\end{array}$} & \multirow[t]{2}{*}{39375} & $\begin{array}{l}\text { Engelhard } \\
\text { DPX }\end{array}$ & 29820 & 509065 \\
\hline Diesel\#2 & 9654 & & & & $\begin{array}{l}\text { Johnson- } \\
\text { Matthey CCRT }\end{array}$ & 29660 & 586458 \\
\hline
\end{tabular}

\section{TEST MATRIX}

The first two John Deere and Cummins buses and the first DDC diesel bus were tested at half load on six drive cycles while the John Deere\#3, Cummins\#3, and Diesel\#2 buses were tested at three load configurations; no load, half load, and full load. No load test weight was calculated by combining the driver's weight to the vehicle's curb weight, while full load weight was determined by combining the vehicle's curb weight with $100 \%$ passenger weight and the driver's weight. Similarly, half load test weight was determined by combining the vehicle's curb weight with driver's weight plus 50\% passenger's weight. Average weight of each passenger and the driver was estimated as $150 \mathrm{lb}$. The first and the second bus were tested on six test cycles each at half load. Emission tests were not repeated for these buses. The third John Deere and Cummins buses and the second diesel bus were tested on three cycles each for un-loaded and fullloaded test weights. Here, tests on every cycle were repeated. Finally, these three buses 
were tested at half-loaded weights on seventeen test cycles including an Idle Mode, where repeat runs were performed for the Idle, the OCTA, and the WMATA cycles only. $\mathrm{N}_{2} \mathrm{O}$ and DNPH were evaluated from these selected buses while being tested at no load and full load weights only. DNPH cartridge analysis was performed by Environment Canada. For every test, $\mathrm{CO}, \mathrm{CO}_{2}$, NOx, $\mathrm{HC}$, and PM were determined. Levels of methane $\left(\mathrm{CH}_{4}\right)$ and non-methane hydrocarbons (NMHC) were evaluated from the natural gas buses. Fuel economy (FE) from these tests for all buses was determined by carbon balance.

\section{DRIVE SCHEDULES}

In this program, one bus each from three technologies was tested on seventeen chassis cycles used in North America and Europe, and the other buses were tested on a subset of these cycles. The first two John Deere and Cummins buses and the first diesel bus were tested at half load on six different drive cycles: the New York Bus Cycle (NYBus) [7], the ADEME-RATP Paris Cycle (Paris) [8], the Manhattan Cycle (Man) [9], the WMATA Cycle [10], the Orange County Transit Authority Cycle (OCTA) [9], and the Braunschweig Cycle (Braun) [11]. The third John Deere and Cummins buses and the second diesel bus were tested at three different load conditions involving the Paris, the OCTA, and the Braunschweig cycles. These buses then were tested at half-loaded state on seventeen drive cycles, including the six test cycles on which the other five buses were tested. Other cycles employed were the New York Composite Cycle (NYComp) [12], the Central Business District Cycle (CBD) [13], the City Suburban Heavy Vehicle Cycle (CSHVC) [14], the first segment of the European Transient Cycle (ETC-Urban) [11], the Beeline Cycle [15], the Transient mode of the Heavy Heavy-Duty Truck Driving Schedule (HHDDTS) [16], the Urban Dynamometer Driving Schedule (UDDS), also known as "Test D" [1], the King County Metro Bus Cycle (KCM) [17], the Arterial (ART) and Commuter (COMM) phases of SAE J1376 [13], and an Idle mode [1818]. Some of the relevant properties of these cycles are presented in Table 2Table 2. Speedtime traces of Manhattan, OCTA, UDDS, Braunschweig, and Paris cycles are presented in Figure 3, Figure 4, Figure 5, Figure 6, and Figure 7, respectively. Note that in this study the CSHVC was used, as a speed-time cycle, rather than the CSHVR, which is a speed-distance route. 
Table 2: Properties of drive cycles, in order of ascending average speed

\begin{tabular}{lcccccc}
\multicolumn{1}{c}{ Cycle ID } & $\begin{array}{c}\text { Time } \\
(\mathrm{sec})\end{array}$ & $\begin{array}{c}\text { Distance } \\
(\mathrm{mile})\end{array}$ & $\begin{array}{c}\text { Average Speed } \\
(\mathrm{mph})\end{array}$ & $\begin{array}{c}\text { Standard } \\
\text { Deviation } \\
(\mathrm{mph})\end{array}$ & $\begin{array}{c}\text { Idle } \\
(\%)\end{array}$ & Stops per mile \\
Idle & 1800 & 0.0 & 0.0 & 0.0 & 100 & N/A \\
NYBus & 600 & 0.61 & 3.69 & 6.48 & 65.67 & 20 \\
Paris & 1909 & 3.55 & 6.74 & 7.37 & 34.91 & 12.1 \\
Man & 1099 & 2.07 & 6.77 & 7.33 & 37.05 & 10.16 \\
WMATA & 1839 & 4.25 & 8.32 & 10.31 & 39.15 & 6.12 \\
NYComp & 1029 & 2.51 & 8.77 & 9.44 & 32.52 & 7.17 \\
OCTA & 1950 & 6.54 & 12.08 & 10.33 & 23.74 & 4.89 \\
CBD & 585 & 2.01 & 12.36 & 8.46 & 21.64 & 7.45 \\
Braunschweig & 1750 & 6.8 & 14.06 & 11.45 & 26.21 & 4.26 \\
ETC-Urban & 600 & 2.36 & 14.13 & 8.44 & 11.27 & 1.28 \\
Beeline & 1724 & 6.79 & 14.17 & 14.74 & 27.61 & 3.68 \\
CSHVC & 1700 & 6.73 & 14.25 & 13.02 & 22.1 & 1.99 \\
Transient & 688 & 2.85 & 14.92 & 13.44 & 18.36 & 1.75 \\
UDDS & 1060 & 5.54 & 18.83 & 19.82 & 33.29 & 2.35 \\
KCM & 1964 & 12.78 & 23.42 & 18.11 & 18.9 & 1.88 \\
Arterial & 292 & 2.0 & 24.66 & 15.66 & 16.63 & 2.0 \\
Commuter & 330 & 4.0 & 43.64 & 19.53 & 12.26 & 0.25
\end{tabular}

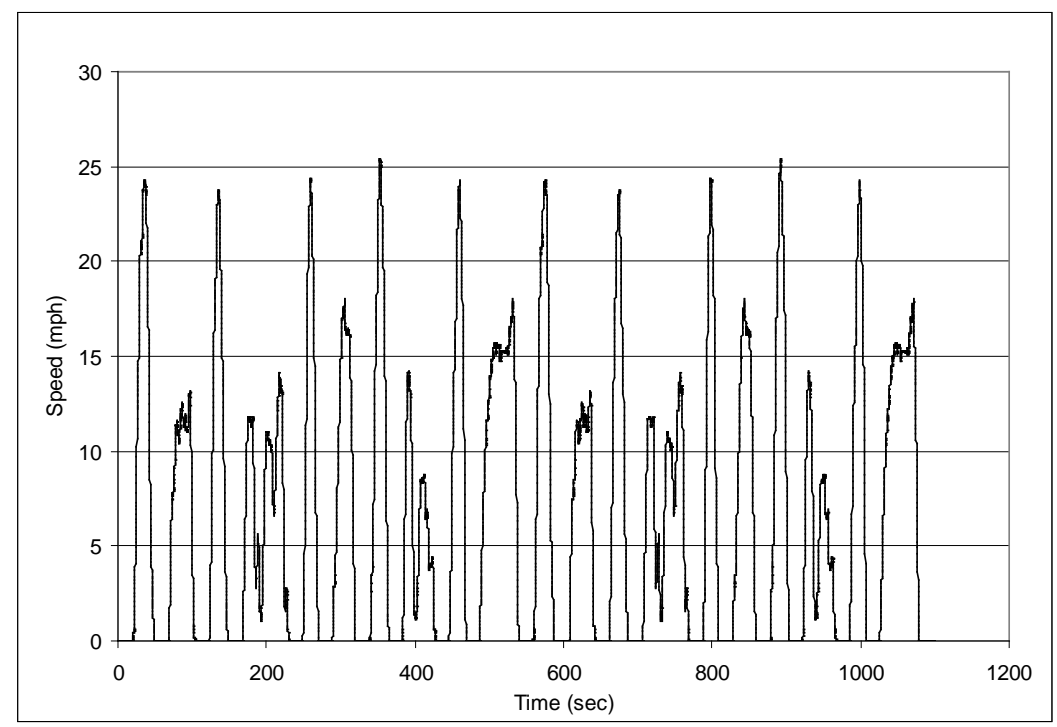

Figure 3: The Manhattan Cycle 


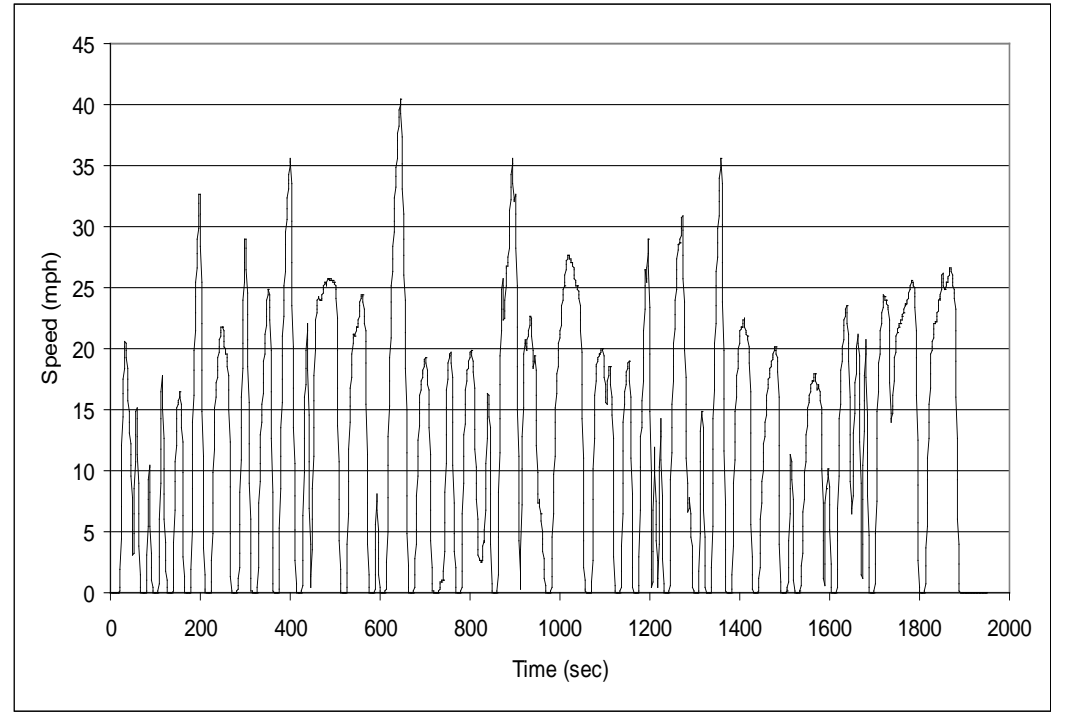

Figure 4: The OCTA Cycle

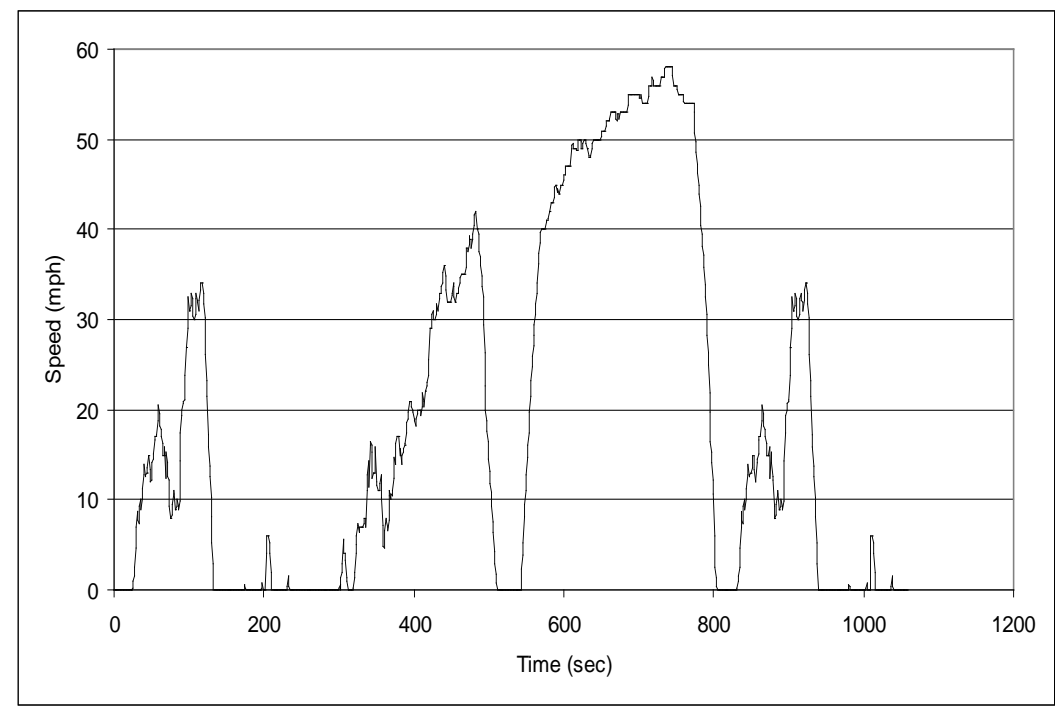

Figure 5: The UDDS Cycle 


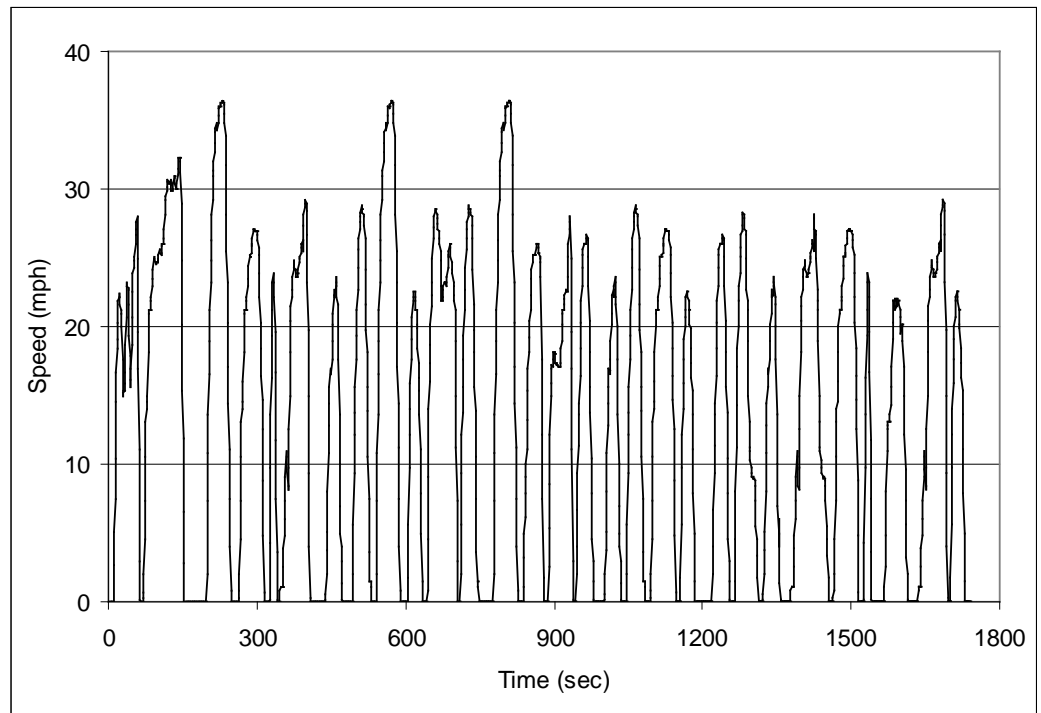

Figure 6: The Braunschweig Cycle

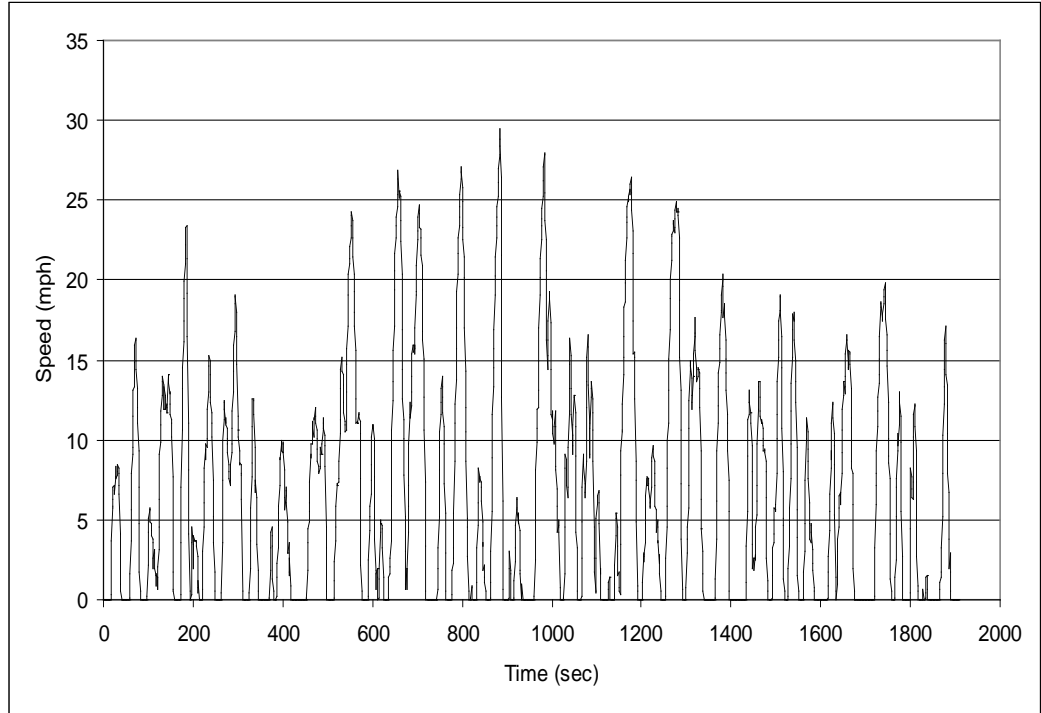

Figure 7: The ADEME Paris Cycle 


\section{REGULATED EMISSIONS}

Actual and Target Speed

Figure 8Figure 8, Figure 9Figure 9, and Figure 10Figure 10 compare the relationship between the actual and target speed employed for the third John Deere bus (Test ID 4669), the third Cummins bus (Test ID 4726), and the second retrofitted diesel bus (Test ID 4842). All these tests were driven on the Braunschweig cycle. The correlation between the actual and target speed resulted in $\mathrm{R}^{2}$ values of about 0.92, 0.93, and 0.96, respectively. The driver was instructed to follow the scheduled trace as closely as possible without driving in a fashion uncharacteristic of real-world operation. Deviation from the parity line often corresponded to acceleration and deceleration events, where small misalignments in time can cause large speed deviations at a point.

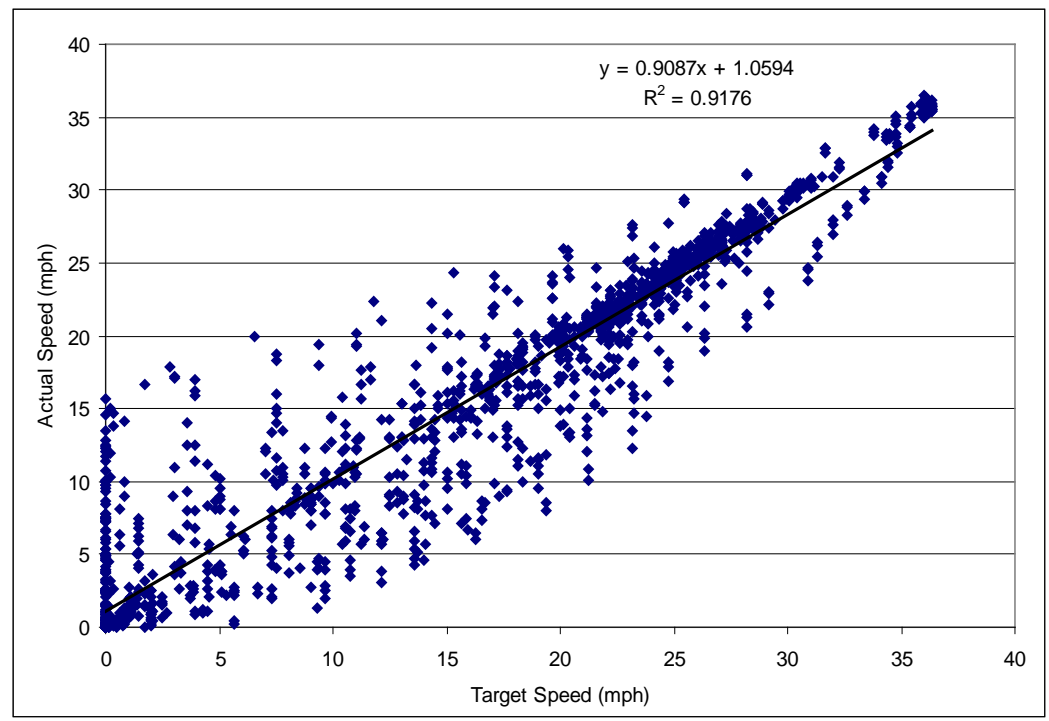

Figure 8: Comparison of the actual and target speed from the third John Deere bus on the Braunschweig Cycle 


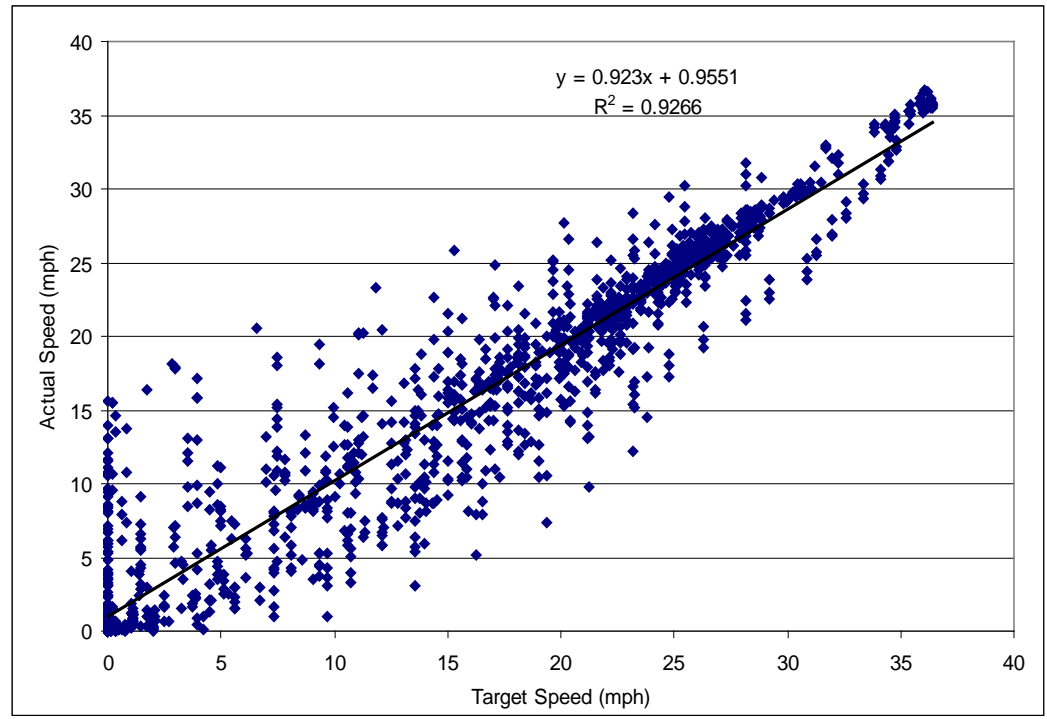

Figure 9: Comparison of the actual and target speed the third Cummins bus on the Braunschweig Cycle

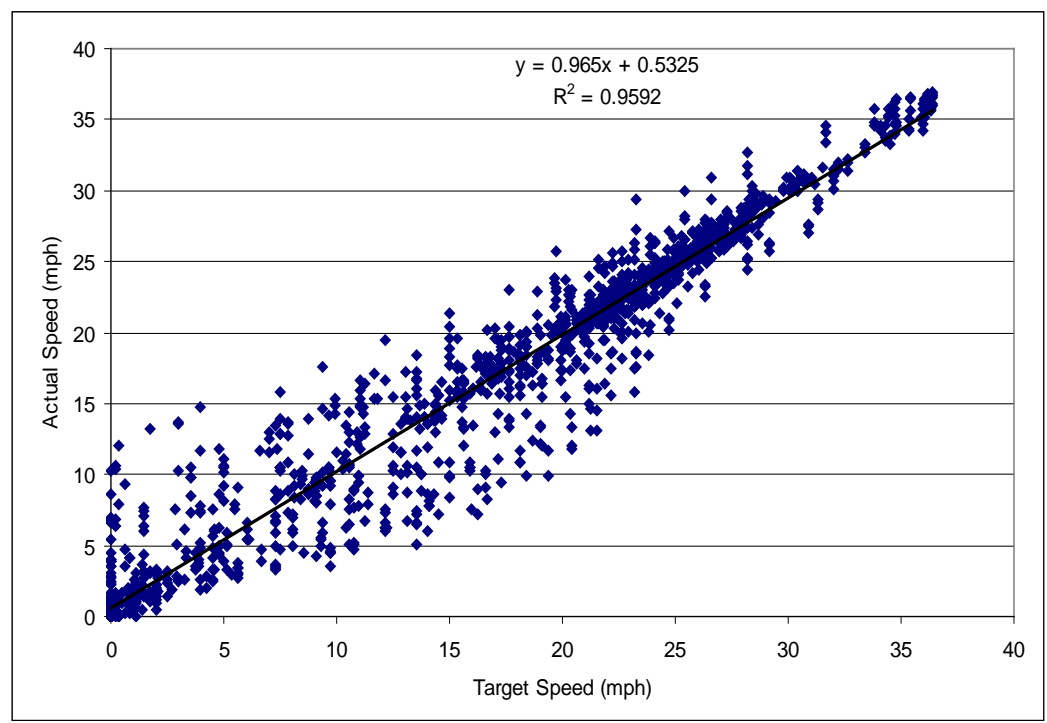

Figure 10: Comparison of the actual and target speed from the second diesel bus on the Braunschweig Cycle 


\section{Continuous $\mathrm{CO}, \mathrm{HC}, \mathrm{NOx}$, and $\mathrm{CO}_{2}$ Emissions}

As example, continuous emissions of $\mathrm{CO}, \mathrm{HC}$, NOx, and $\mathrm{CO}_{2}$ from the third John Deere bus for the Braunschweig Cycle are presented in Figure 11Figure 11, Figure 12Figure 12, Figure 13Figure 13, and Figure 14Figure 14, respectively while continuous NOx emissions from the third Cummins NGB and the second Retrofitted diesel bus are presented in Figure 15Figure 15, and Figure 16Figure 16, respectively.

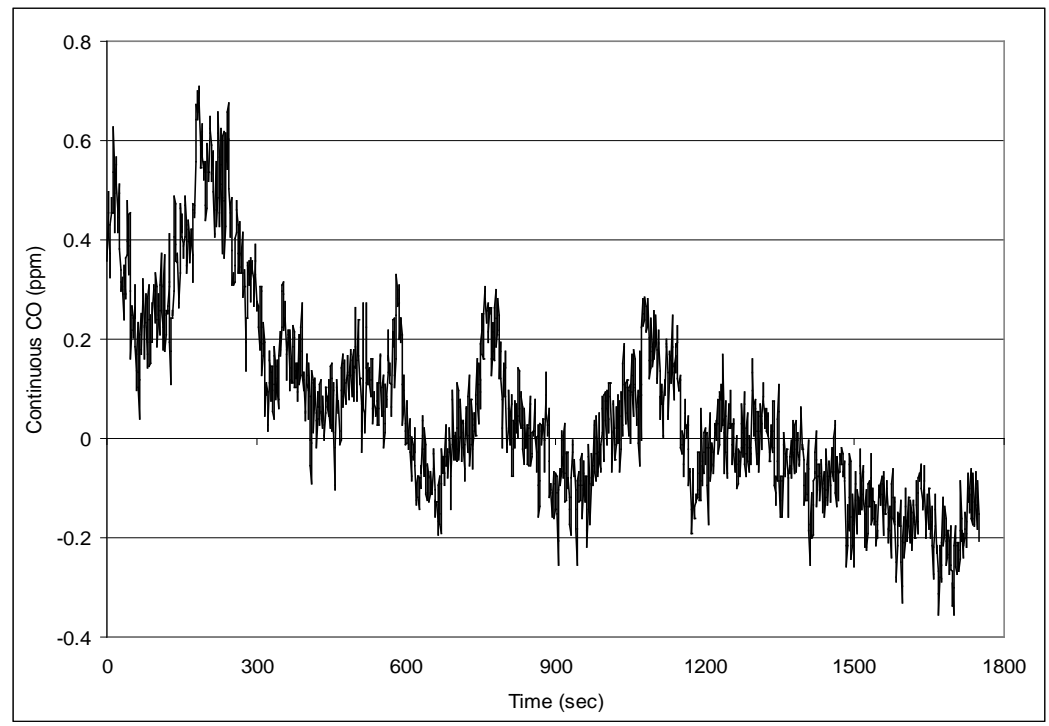

Figure 11: Continuous CO emissions from the third John Deere bus on the Braunschweig Cycle. Clearly the CO level is at the detection level of the analyzer. 


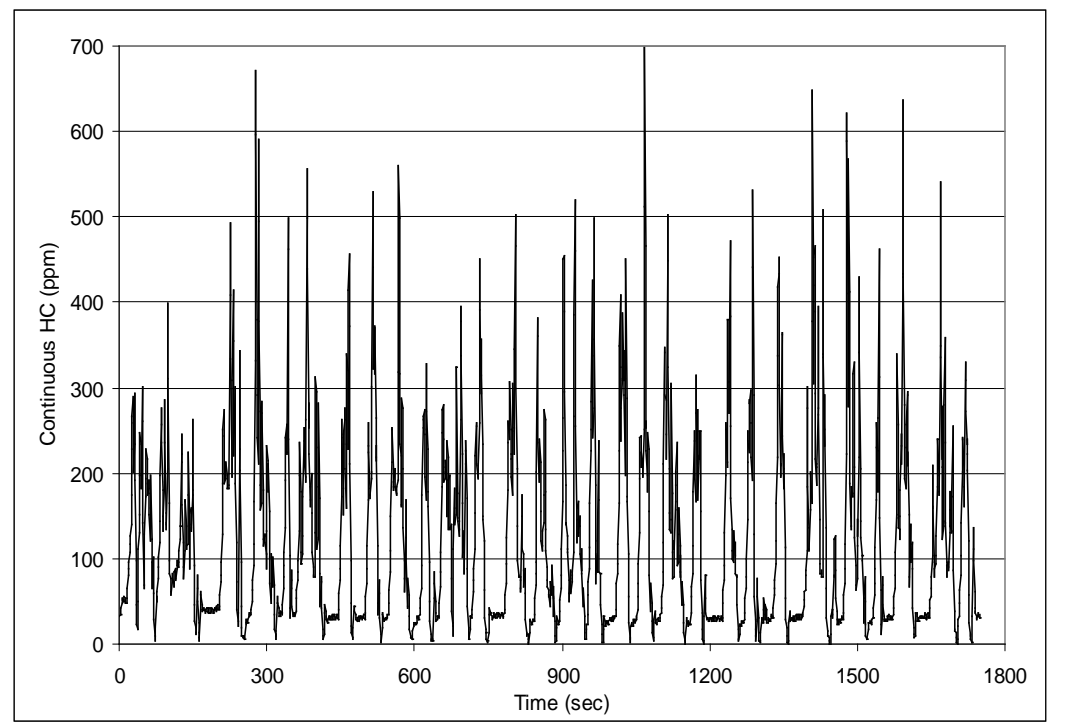

Figure 12: Continuous HC emissions from the third John Deere bus on the Braunschweig Cycle

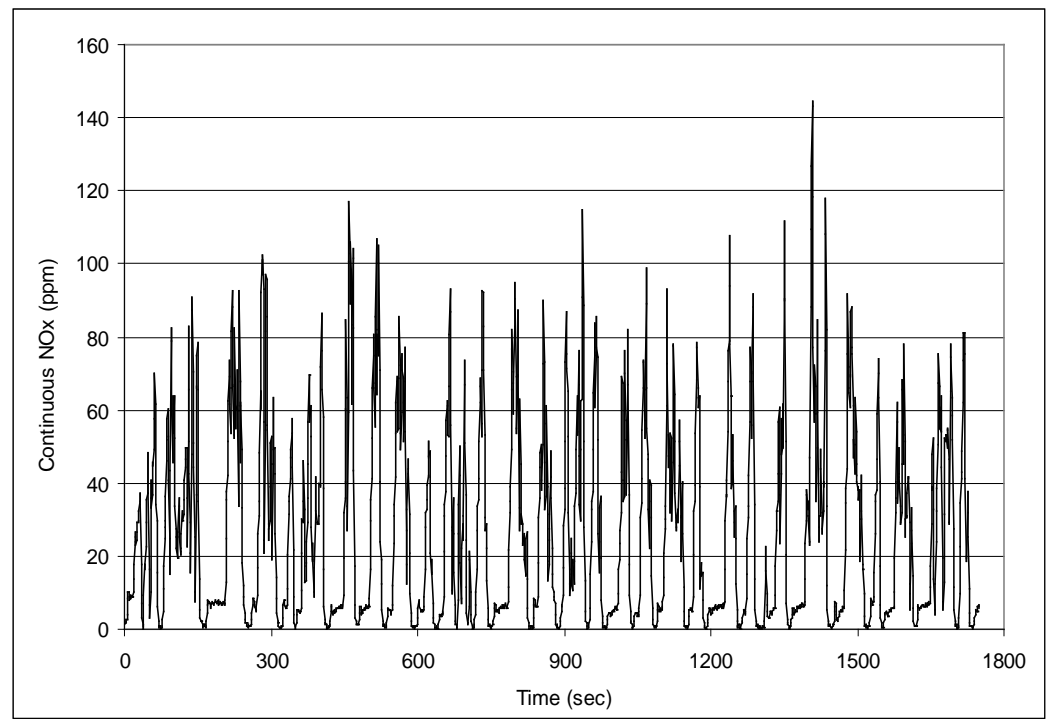

Figure 13: Continuous NOx emissions from the third John Deere bus on the Braunschweig Cycle 


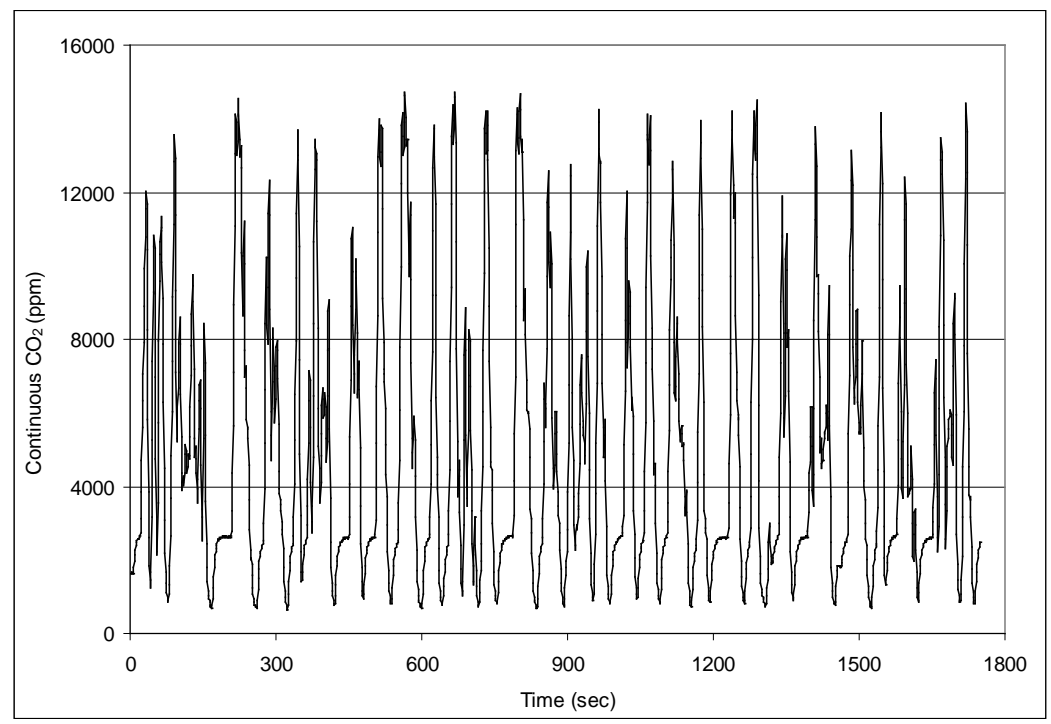

Figure 14: Continuous $\mathrm{CO}_{2}$ emissions from the third John Deere bus on the Braunschweig Cycle

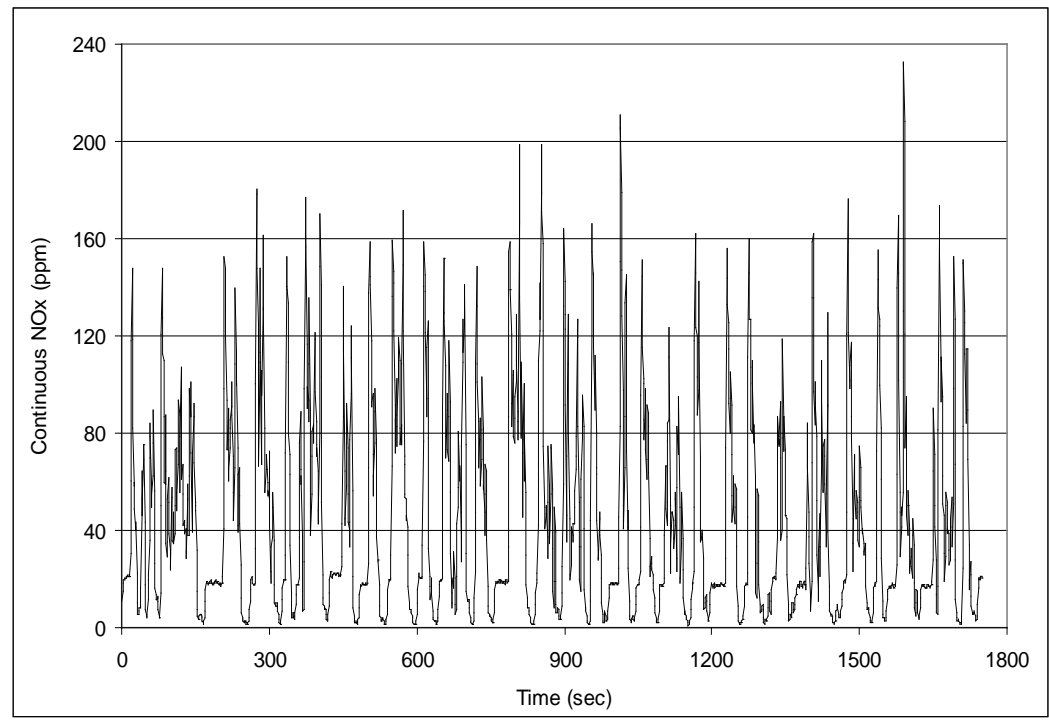

Figure 15: Continuous NOx emissions from the third Cummins bus on the Braunschweig Cycle 


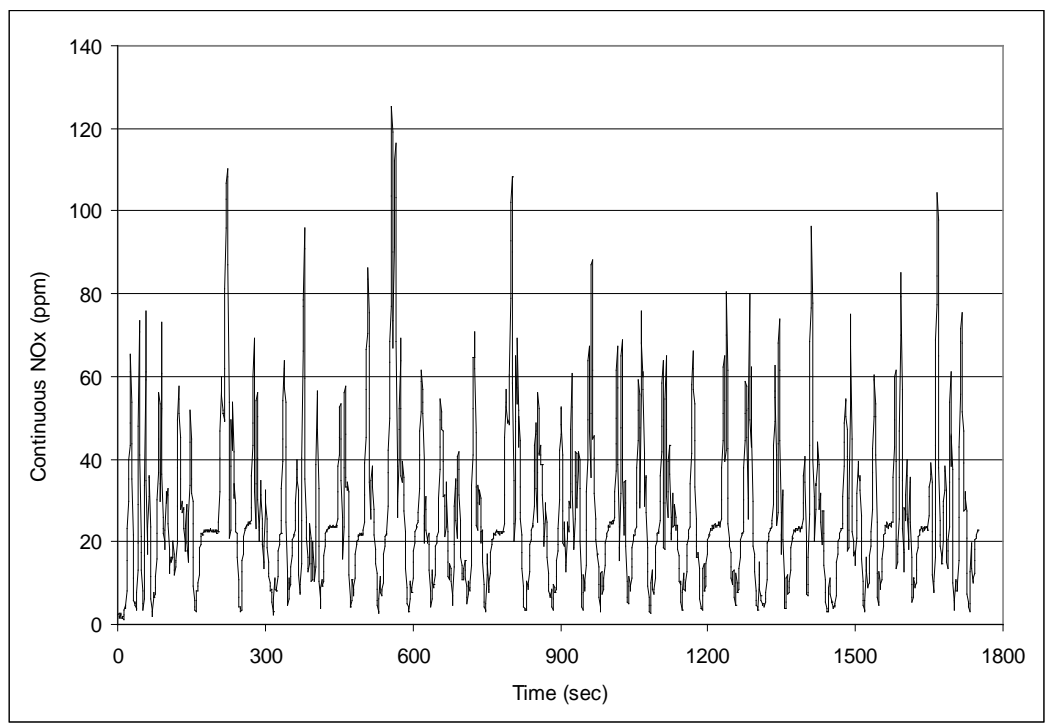

Figure 16: Continuous NOx emissions from the second diesel bus on the Braunschweig Cycle

\section{CYCLE AVERAGED REGULATED EMISSIONS}

Cycle average emissions and FE from the lean-burn natural gas and diesel buses are discussed in the following sections.

John Deere Natural Gas Buses

Distance-specific cycle-average CO, HC, NOx, and PM emissions from three John Deere natural gas buses are presented in Figure 17Figure 17, Figure 18Figure 18, Figure

19Figure 19, and Figure 20Figure 20, respectively. The NYBus Cycle elicited the highest distance-specific emissions of these pollutants from all three buses. Overall, CO emissions from these buses were very low and in some cases were below the detectable limit of the Translab (BDL). The highest CO emissions from these buses were 0.46 $\mathrm{g} / \mathrm{mile}$ on the NYBus Cycle from the first bus followed by $0.42 \mathrm{~g} / \mathrm{mile}$ on the Manhattan Cycle from the third bus. HC emissions varied from $6.39 \mathrm{~g} / \mathrm{mile}$ on the Commuter Cycle from the third bus to $57.7 \mathrm{~g} / \mathrm{mile}$ on the NYBus Cycle from the third bus. NOx emissions from these buses varied from $5.6 \mathrm{~g} / \mathrm{mile}$ on the Commuter Cycle from the third bus to $44.2 \mathrm{~g} / \mathrm{mile}$ on the NYBus Cycle from the second bus. The NYBus Cycle exhibited the highest NOx emissions from all three buses followed by the NYComp Cycle, which exhibited $28.5 \mathrm{~g} / \mathrm{mile}$ from the third bus. PM emissions from these buses were very low ranging from $0.006 \mathrm{~g} / \mathrm{mile}$ on the WMATA Cycle from the third bus to $0.14 \mathrm{~g} / \mathrm{mile}$ on the 
NYBus Cycle from the first bus. In some cases PM emissions challenged the detection limit of the laboratory.

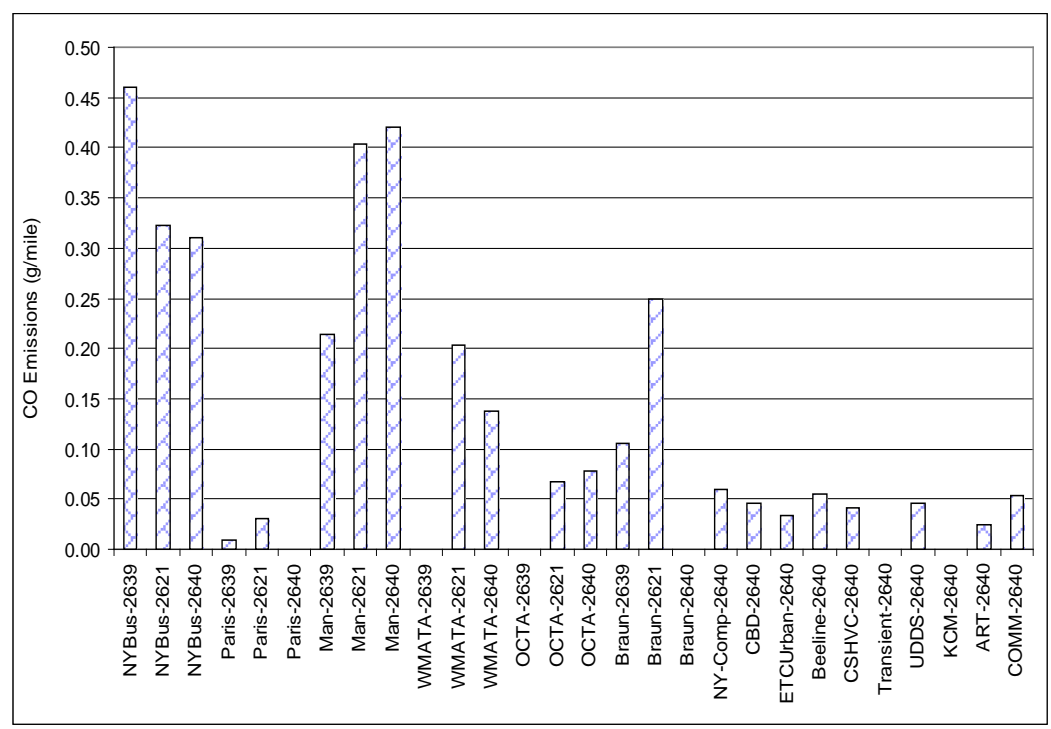

Figure 17: Cycle averaged CO emissions (bag data) from John Deere natural gas buses (g/mile). The $\mathrm{X}$-axis shows the cycles used (Table 2 ) and the bus number (Table 1). 


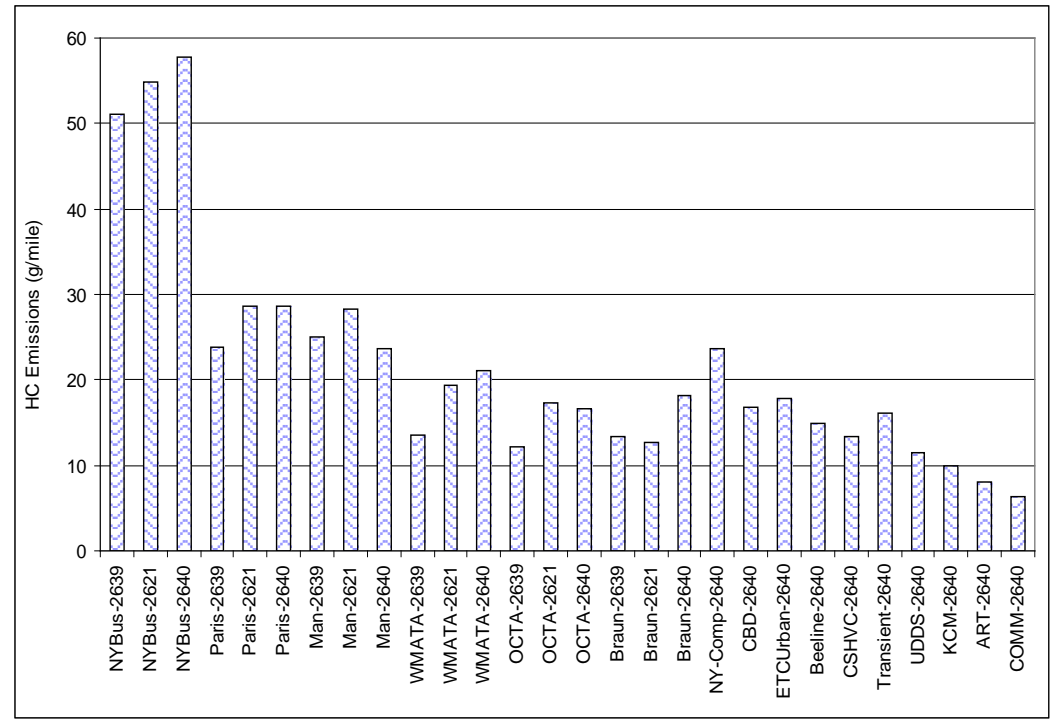

Figure 18: Cycle averaged HC emissions from John Deere natural gas buses (g/mile)

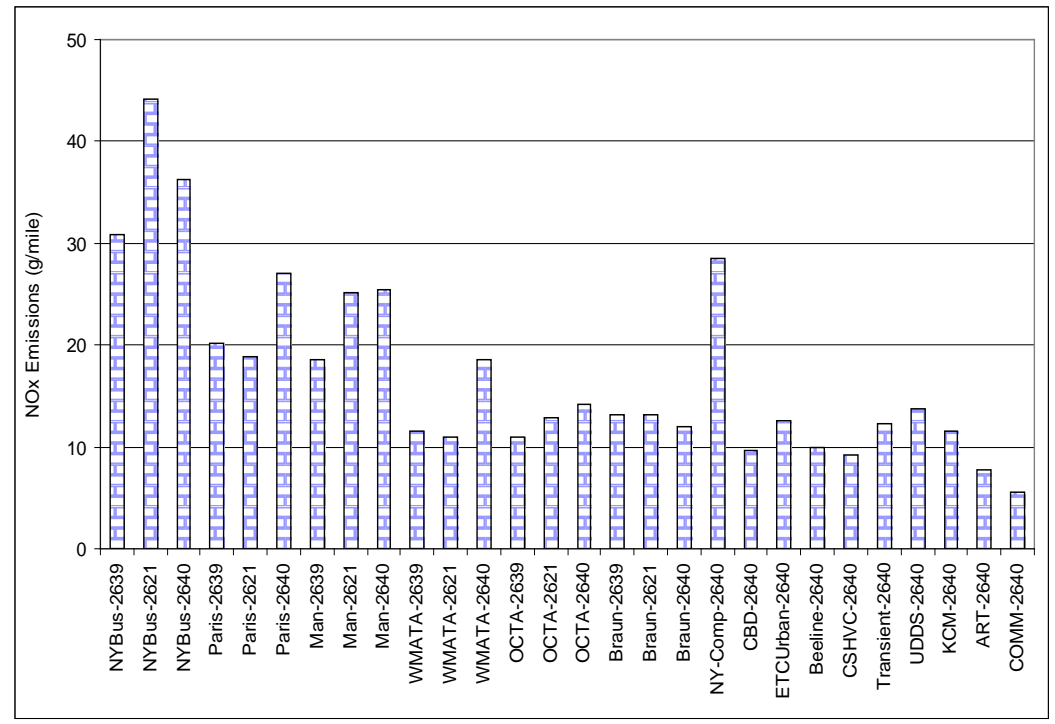

Figure 19: Cycle averaged NOx emissions from John Deere natural gas buses (g/mile) 


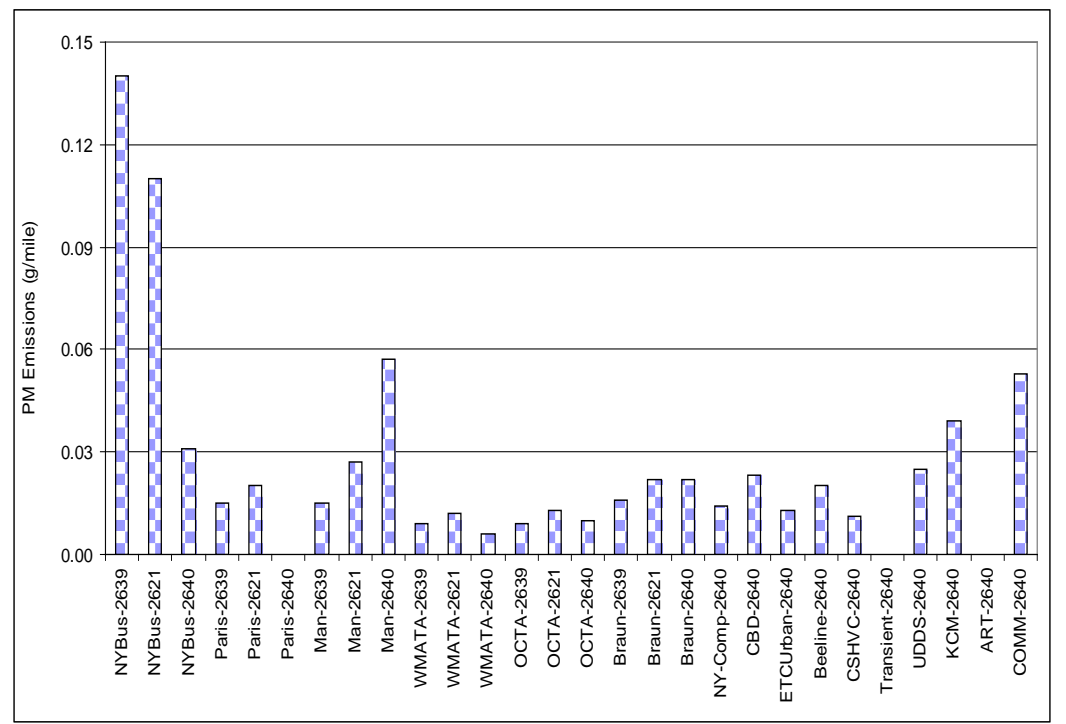

Figure 20: Cycle averaged PM emissions from John Deere natural gas buses (g/mile)

\section{Cummins Natural Gas Buses}

Distance-specific cycle average CO, HC, NOx, and PM emissions from three Cummins natural gas buses are presented in Figure 21Figure 21, Figure 22Figure 22, Figure 23Figure 23, and Figure 24Figure 24, respectively. The second bus emitted the highest CO emissions on the Paris Cycle although the NYBus Cycle exhibited the high CO emissions from all three buses, on average. CO ranged from $0.115 \mathrm{~g} / \mathrm{mile}$ on the ETCUrban Cycle from the third bus to $3.767 \mathrm{~g} / \mathrm{mile}$ on the Paris Cycle from the second bus. There was a strong variability in $\mathrm{CO}$ levels between the three Cummins buses on several cycles (see, for example, the Paris and the Manhattan cycles), but the NOx and HC levels were similar for the three buses. The slow speed cycles exhibited high HC emissions while the high speed cycles exhibited low HC emissions from these buses. HC emissions varied from $9.48 \mathrm{~g} / \mathrm{mile}$ on the Commuter Cycle from the third bus to $86.8 \mathrm{~g} / \mathrm{mile}$ on the NYBus Cycle from the second bus. NOx emissions from these buses varied from 6.04 $\mathrm{g} / \mathrm{mile}$ on the Commuter Cycle from the third bus to $71.1 \mathrm{~g} / \mathrm{mile}$ on the NYBus Cycle from the same bus. The NYBus Cycle exhibited the highest NOx emissions from all three buses followed by the Paris and the Manhattan cycles. PM emissions from these buses were very low ranging from $0.003 \mathrm{~g} / \mathrm{mile}$ on the CSHVC from the third bus to 0.063 $\mathrm{g} / \mathrm{mile}$ on the NYBus Cycle from the second bus. 


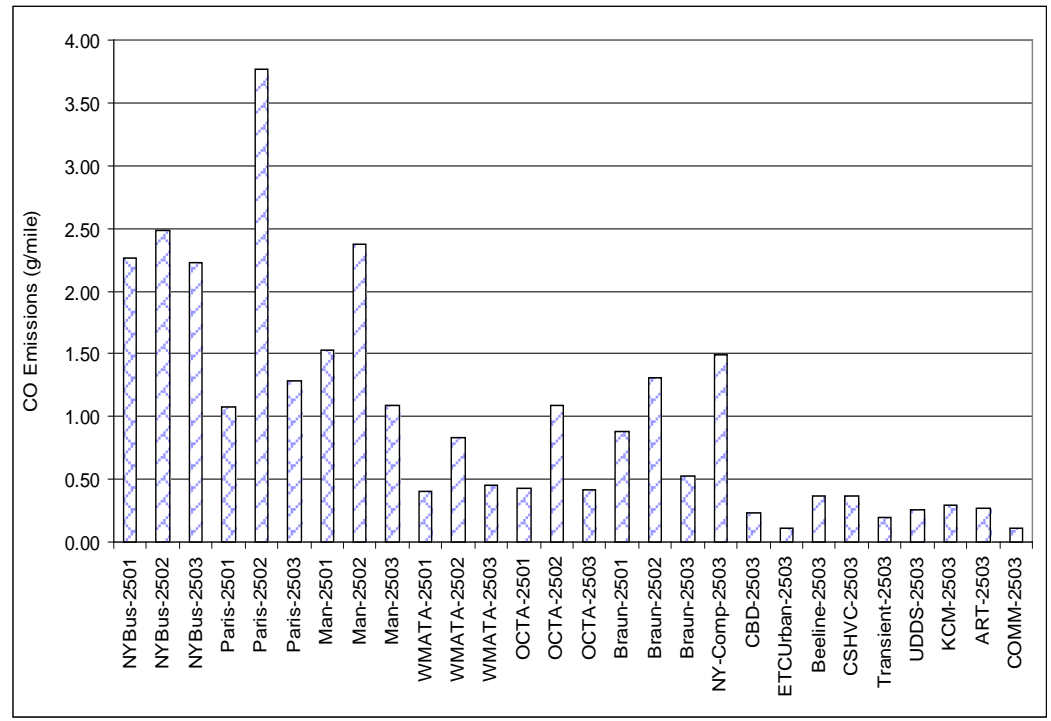

Figure 21: Cycle averaged CO emissions from Cummins natural gas buses (g/mile)

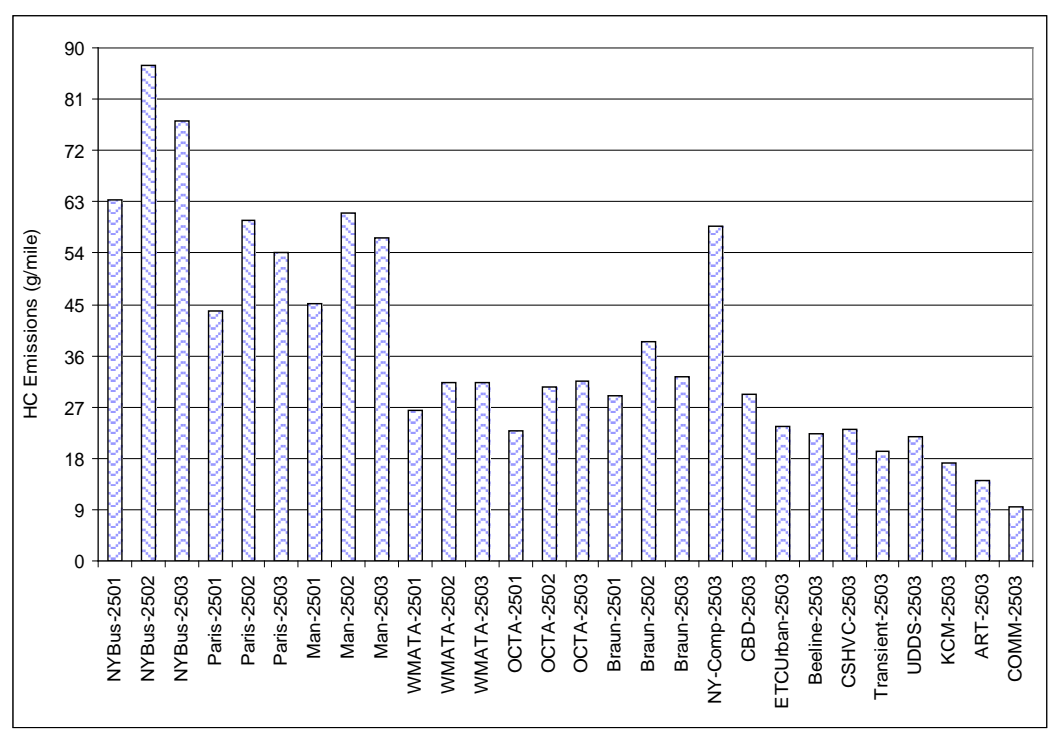

Figure 22: Cycle averaged HC emissions from Cummins natural gas buses (g/mile) 


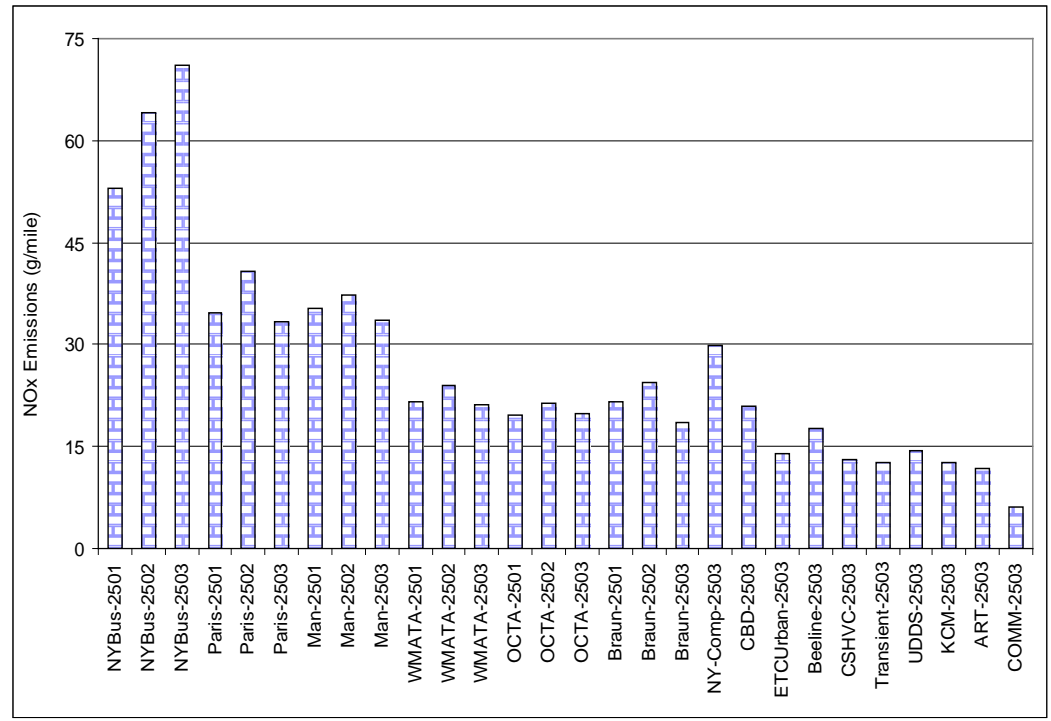

Figure 23: Cycle averaged NOx emissions from Cummins natural gas buses (g/mile)

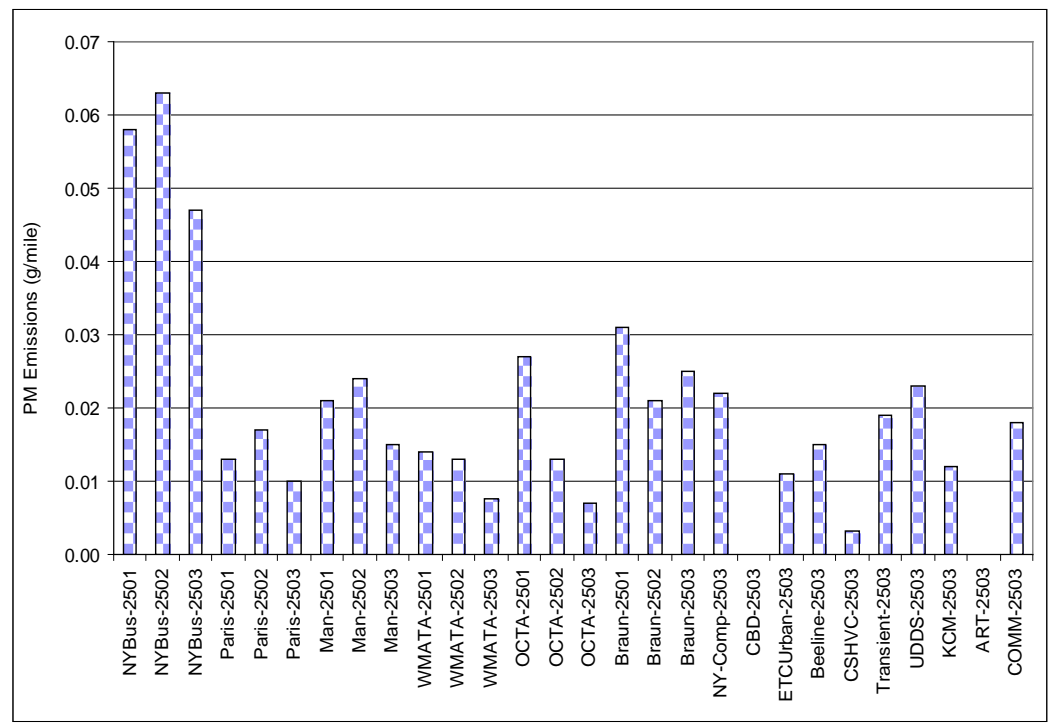

Figure 24: Cycle averaged PM emissions from Cummins natural gas buses (g/mile) 


\section{Retrofitted Diesel Buses}

Distance-specific cycle average CO, HC, NOx, and PM emissions from two retrofitted DDC diesel buses are presented in Figure 25Figure 25, Figure 26Figure 26, Figure 27Figure 27, and Figure 28Figure 28, respectively. Note that the two buses used different aftertreatment systems, as presented in Table 1 . It has been suggested by the manufacturer that exhaust gas recirculation (EGR) on the first bus may not have functioned properly at the time of testing. The first bus showed high CO and NOx than the second bus and poorer fuel economy. Therefore data from the second bus would only be considered for future analyses. The NYBus Cycle exhibited the highest emissions of these pollutants from two buses. $\mathrm{CO}$ and $\mathrm{HC}$ emissions from these buses were very low and in some cases were below the detectable limit. The highest $\mathrm{CO}$, exhibited from the first bus was $1.835 \mathrm{~g} / \mathrm{mile}$ on the NYBus Cycle while the highest HC emissions were $0.44 \mathrm{~g} /$ mile on the same cycle from the same bus. However, both CO and HC emissions could not be detected from the second bus on the NYBus Cycle. The first bus on the NYBus Cycle emitted the highest $\mathrm{NOx}$ and $\mathrm{CO}_{2}$ emissions, while the second bus emitted the highest PM emissions on the NYBus Cycle. NOx emissions varied from $5.74 \mathrm{~g} / \mathrm{mile}$ on the Commuter Cycle from the second bus to $71.6 \mathrm{~g} / \mathrm{mile}$ on the NYBus Cycle from the first bus. PM emissions from this bus were very low ranging from $0.003 \mathrm{~g} / \mathrm{mile}$ on the WMATA Cycle from the first bus to $0.07 \mathrm{~g} / \mathrm{mile}$ on the NYBus Cycle from the second bus.

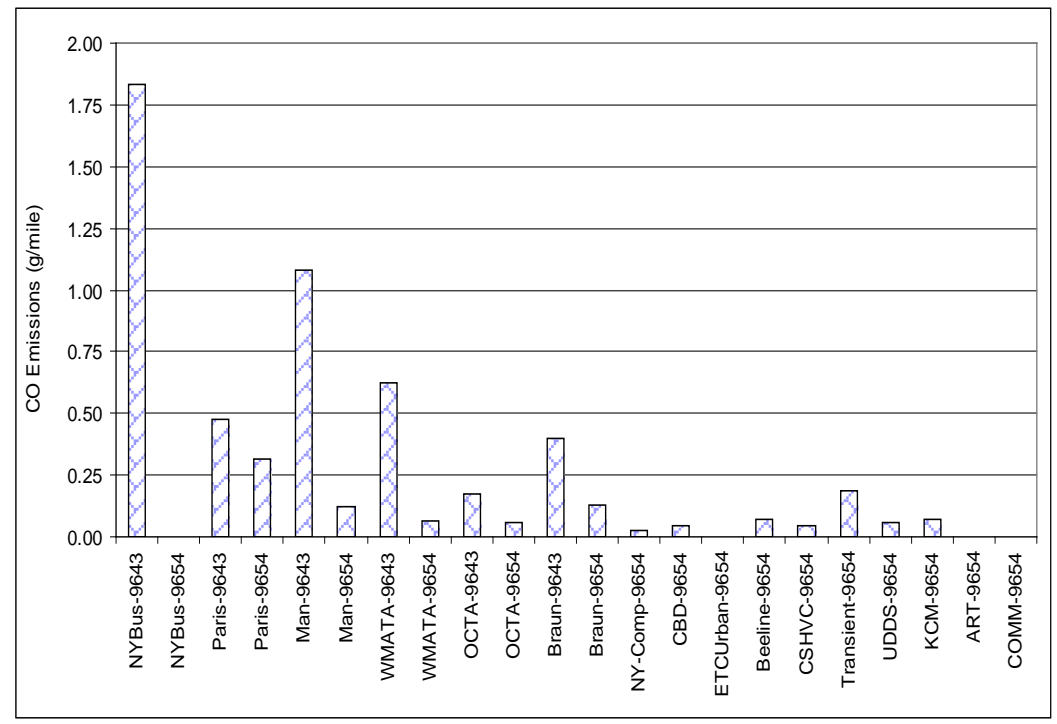

Figure 25: Cycle averaged CO emissions from retrofitted diesel buses ( $\mathrm{g} / \mathrm{mile})$. The values of $\mathrm{CO}$ that were zero or negative were considered to be below the detectable limit and are shown as a zero value. 


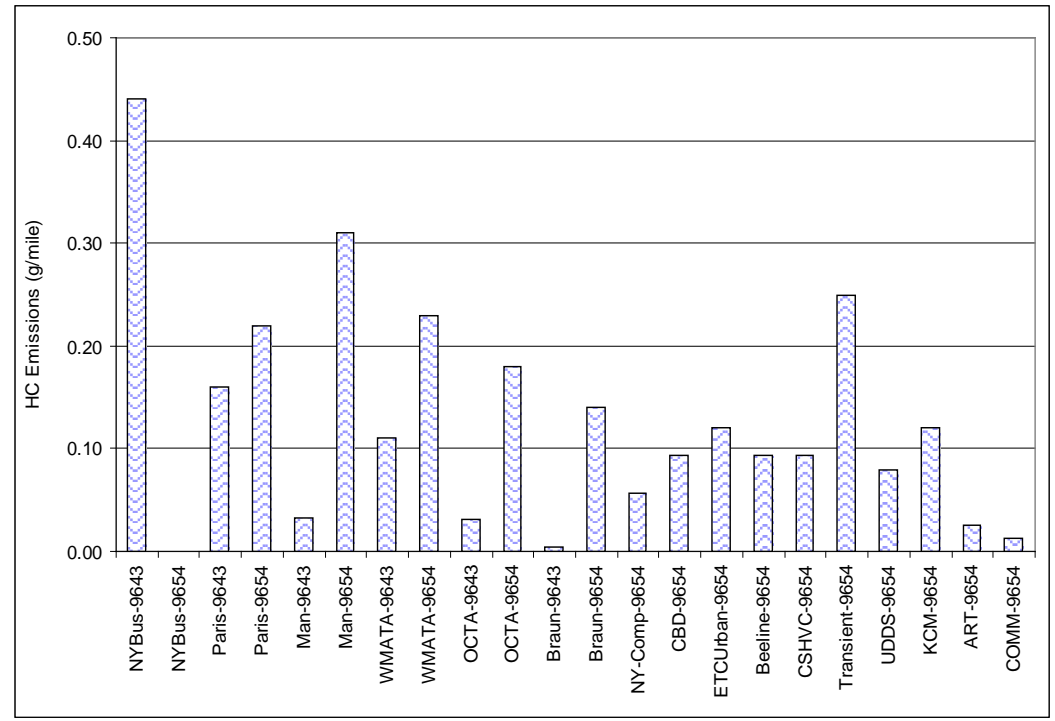

Figure 26: Cycle averaged HC emissions from retrofitted diesel buses (g/mile)

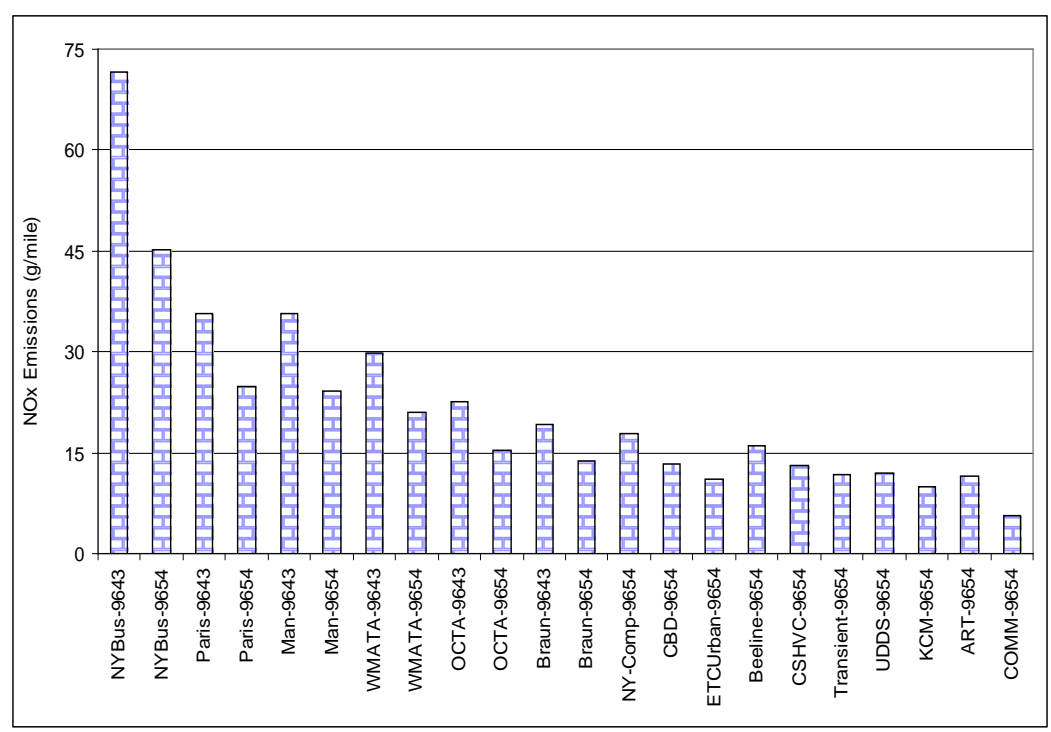

Figure 27: Cycle averaged NOx emissions from retrofitted diesel buses (g/mile) 


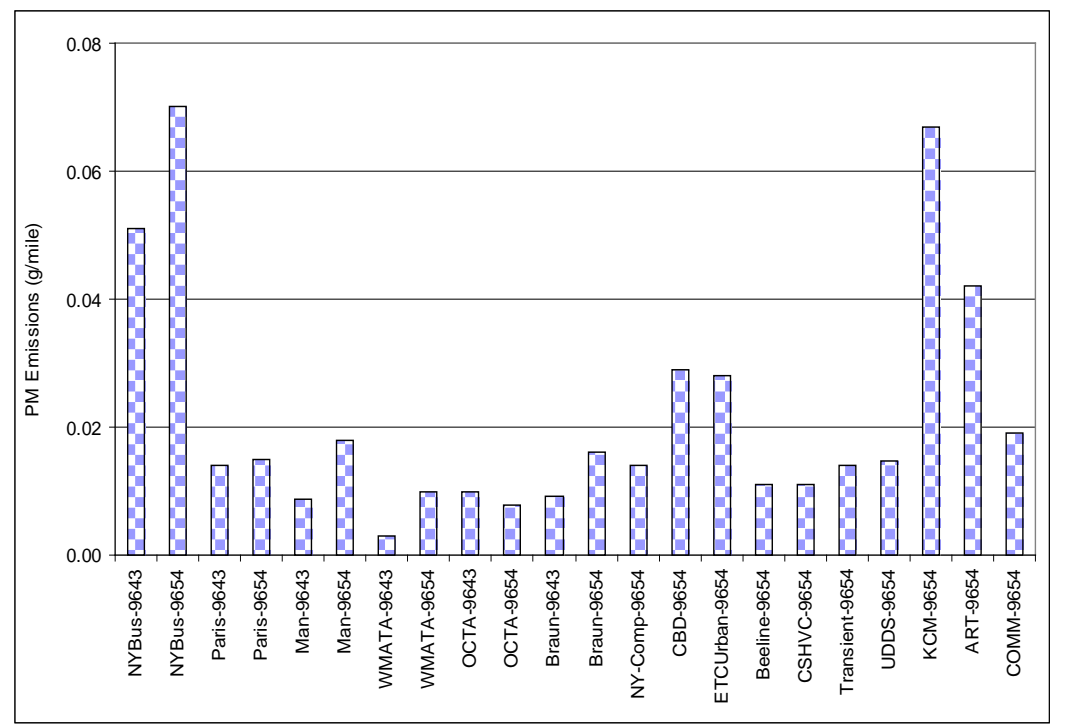

Figure 28: Cycle averaged PM emissions from retrofitted diesel buses (g/mile)

\section{IDLE EMISSIONS}

Idle emissions of $\mathrm{CO}, \mathrm{HC}$, NOx, PM, and $\mathrm{CO}_{2}$ were evaluated from John Deere\#3 and Cummins\#3 natural gas buses and from Diesel\#2 bus. These buses were kept at idle for | 1800 seconds while collecting these emissions data. Figure 29Figure 29 presents idle emissions from these buses. Idle CO emissions were very low from natural gas buses, ranging from 1.155 grams per hour (g/hr) from the John Deere bus to $1.197 \mathrm{~g} / \mathrm{hr}$ from the Cummins bus. Idle CO from the diesel bus was below the detectable limit. The John Deere and the Cummins natural gas buses emitted high HC emissions (37.38 g/hr and $38.67 \mathrm{~g} / \mathrm{hr}$, respectively) and low NOx emissions (5.68 g/hr and $9.06 \mathrm{~g} / \mathrm{hr}$, respectively) while the diesel bus emitted the highest idle NOx emissions (79.47 g/hr). HC emissions from the diesel bus were below the detectable limit. Idle PM from the Cummins bus was below the detectable limit while it was about $0.125 \mathrm{~g} / \mathrm{hr}$ from the John Deere bus. Idle PM emissions were very low from the diesel bus $(0.009 \mathrm{~g} / \mathrm{hr})$. Idle $\mathrm{CO}_{2}$ emissions from the diesel bus were comparatively lower than those from the natural gas buses. The diesel bus emitted $5578 \mathrm{~g} / \mathrm{hr}$ of idle $\mathrm{CO}_{2}$ while the John Deere and Cummins buses emitted $6002 \mathrm{~g} / \mathrm{hr}$ and $5867 \mathrm{~g} / \mathrm{hr}$ of $\mathrm{CO}_{2}$ emissions, respectively. 


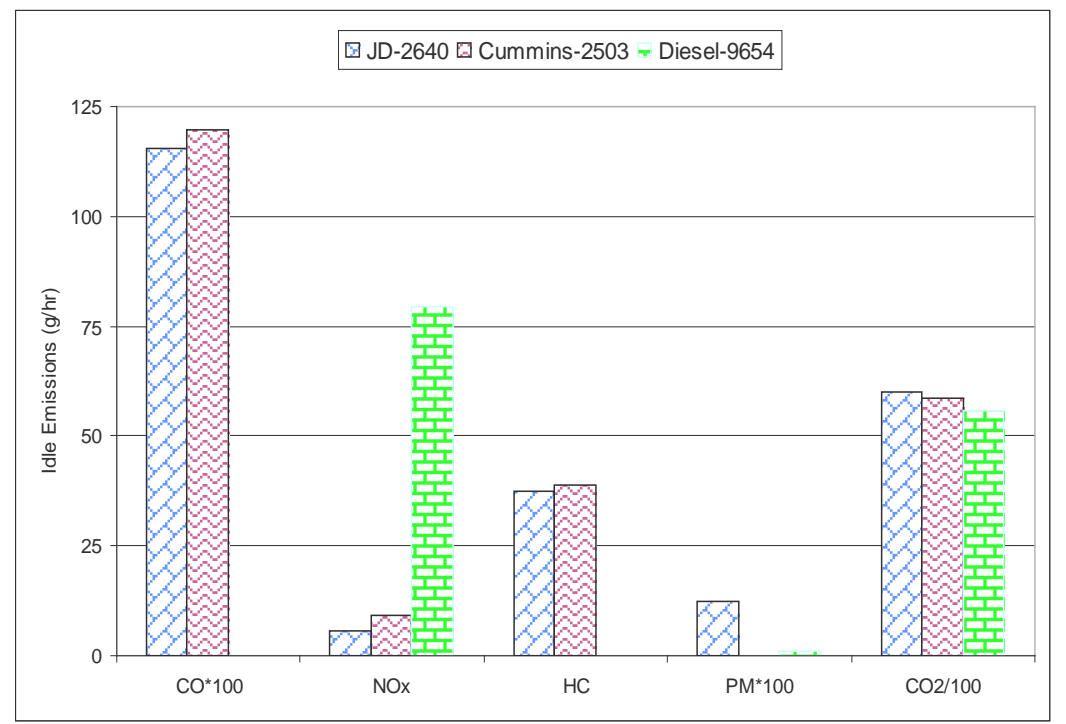

Figure 29: Comparison of idle emissions from the John Deere and Cummins natural gas buses and the retrofitted diesel bus. Note that $\mathrm{CO}$ and PM scales are increased a 100 fold while $\mathrm{CO}_{2}$ scale was decreased a 100 fold.

\section{EFFECT OF TEST WEIGHT ON EMISSIONS AND FE}

Three buses representing John Deere, Cummins, and the Retrofitted diesel were tested at | three load conditions. Load specifications are presented in Table 3Table 3.

Table 3: Load specification for no load, half load, and full load testing

\begin{tabular}{|l|c|c|c|c|c|}
\hline Bus ID & \multirow{2}{*}{$\begin{array}{c}\text { Gross } \\
\text { Vehicle } \\
\text { Weight (lb) }\end{array}$} & $\begin{array}{c}\text { Curb Weight } \\
\text { (lb) }\end{array}$ & & \multicolumn{3}{|c|}{ Test Weight (lb) } \\
\cline { 3 - 6 } & 42540 & 32320 & 32470 & 36970 & 41470 \\
\hline John Deere & 42540 & 32300 & 32450 & 36950 & 41450 \\
\hline Cummins & 39375 & 29660 & 29810 & 34610 & 39410 \\
\hline $\begin{array}{l}\text { Retrofitted } \\
\text { Diesel (DDC) }\end{array}$ & & & & & Holf Load Load \\
\hline
\end{tabular}

To interpret the data gained at different bus weights a basic model was developed based on an energy requirement assessment. The effect of operating weight on fuel consumption was explained using the road load equation, drivetrain efficiency, and 
auxiliary loads. Fuel consumption should be affected by the power demanded of the engine. A prediction model was developed to project the ratio of fuel consumption between two operating weights. It was found that the predicted ratios would vary from approximately 0.83 to 0.94 for a 40 foot transit bus depending on component efficiencies, auxiliary loads, and the nature of driving cycles. Details are presented in an SAE Paper [19].

Three common cycles; the Braunschweig Cycle, the Paris Cycle, and the OCTA Cycle, were employed to examine the effects of test weight on emissions and FE. The effect of these three test weights on emissions and FE from the third John Deere bus on the OCTA, the Paris, and the Braunschweig cycles are presented in Figure 30Figure 30 , Figure 31Figure 31, and Figure 32Figure 32, respectively. $\mathrm{CO}$ and $\mathrm{CO}_{2}$ from the John Deere bus increased with increasing test weights on the Paris and the Braunschweig cycles, while $\mathrm{CO}_{2}$ decreased at full load in comparison to the half load on the OCTA cycle. HC, NOx, and PM from this bus presented a mixed effect. NOx emissions from this bus varied considerably on all cycles, but did not follow a trend of increment with increasing test weights. NOx was significantly higher at half load than that at the other two test weights. Test weight from this bus increased by about $28 \%$ from the empty weight to the full test weight. This small difference might not have been sufficient to project the difference in NOx emissions due to the test weight. FE from this bus decreased with increasing weights on the Braunschweig Cycle, while half and full load weights did not affect FE on the Paris Cycle. 


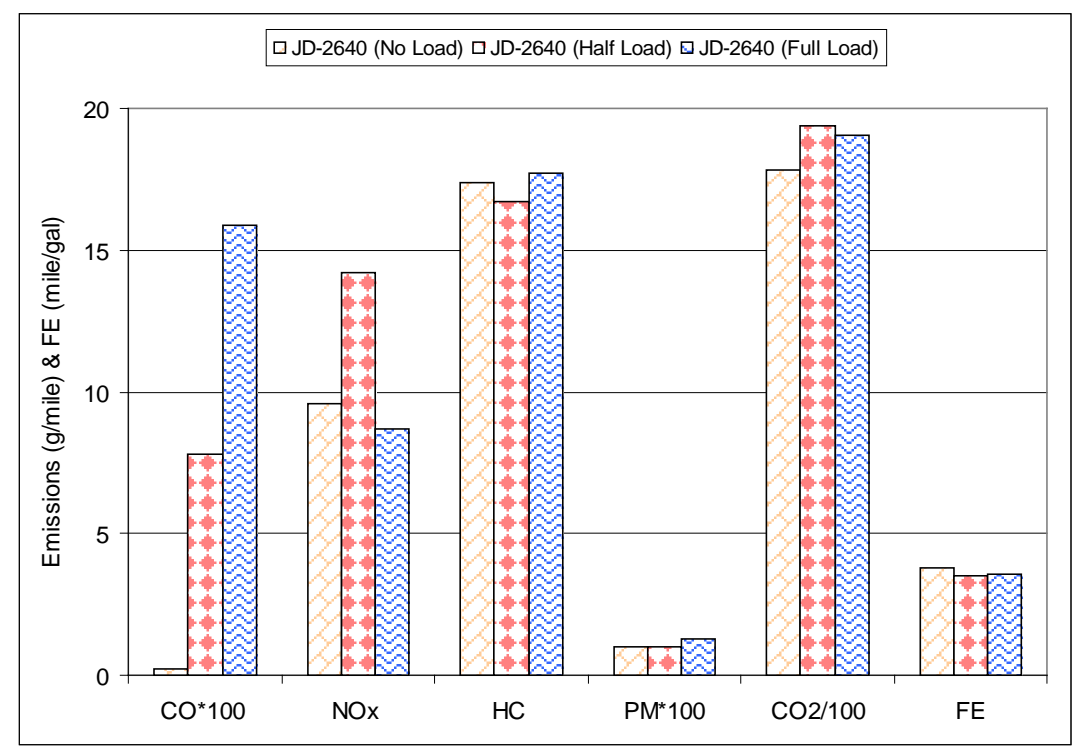

Figure 30: Weight effect on the third John Deere bus on the OCTA Cycle. Note that CO and PM scales were increased a 100 fold while $\mathrm{CO}_{2}$ scale was decreased a 100 fold.

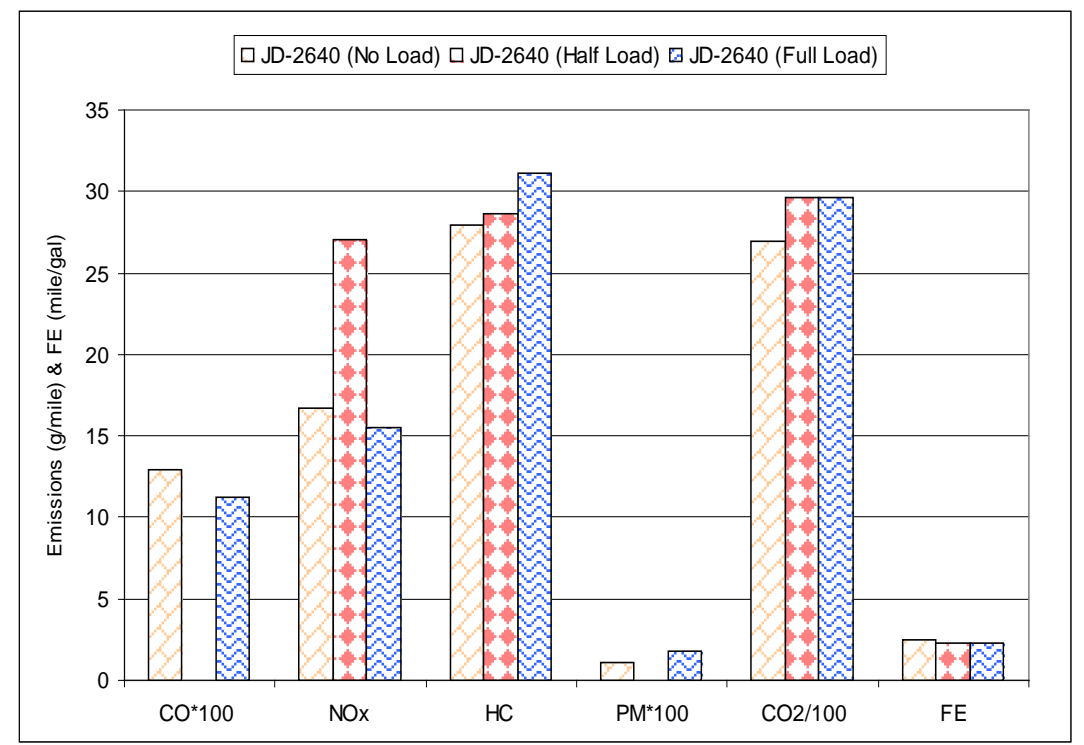

Figure 31: Weight effect on the third John Deere bus on the Paris Cycle 


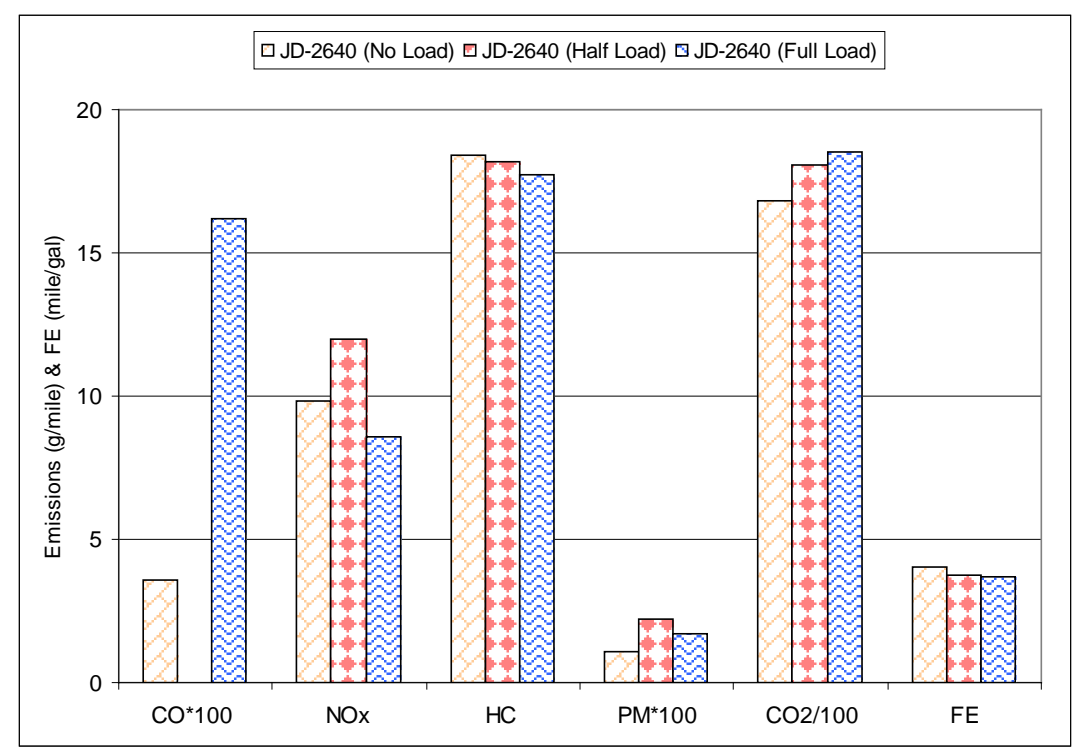

Figure 32: Weight effect on the third John Deere bus on the Braunschweig Cycle

| Figure 33Figure 33, Figure 34Figure 34, and Figure 35Figure 35, shows the effect of test weight on emissions and FE from the Cummins bus on the OCTA, the Paris, and the Braunschweig cycles, respectively. Mixed effects were observed for CO, NOx, HC, and PM emissions from this bus with varying test weights. HC emissions from this bus were high at half-loaded state on all cycles while CO and PM did not exhibit any trend with test weights. NOx emissions from this bus were higher at full load than those at no load test weights on all cycles. However, no difference in NOx emissions at half and full load weights was observed. $\mathrm{CO}_{2}$ emissions from this bus increased with increasing test weights on all cycles and conversely FE decreased with increasing test weights on all cycles. 


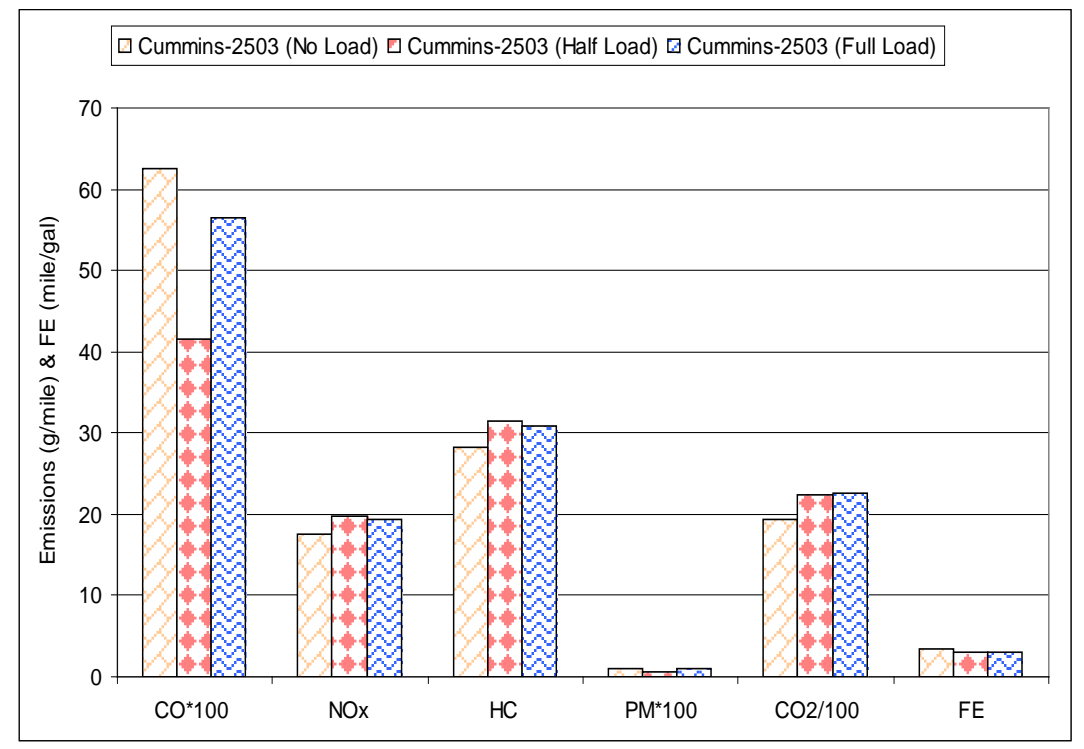

Figure 33: Weight effect on the third Cummins bus on the OCTA Cycle. Note that CO and PM scales were increased a 100 fold while $\mathrm{CO}_{2}$ scale was decreased a 100 fold.

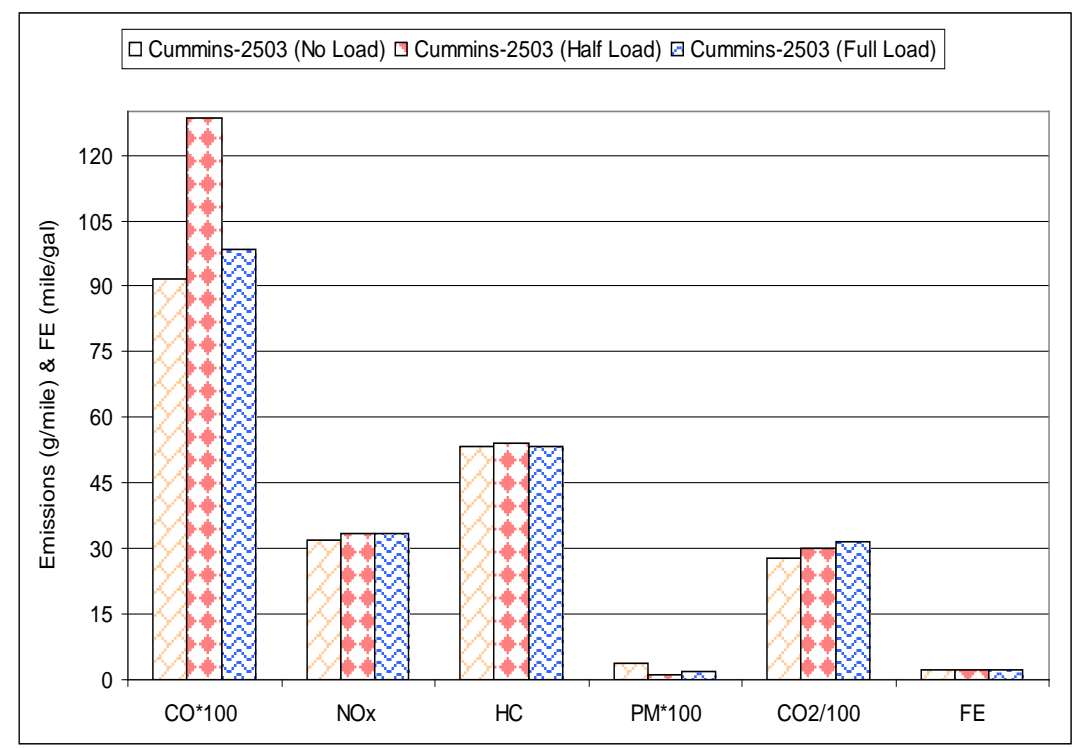

Figure 34: Weight effect on the third Cummins bus on the Paris Cycle 


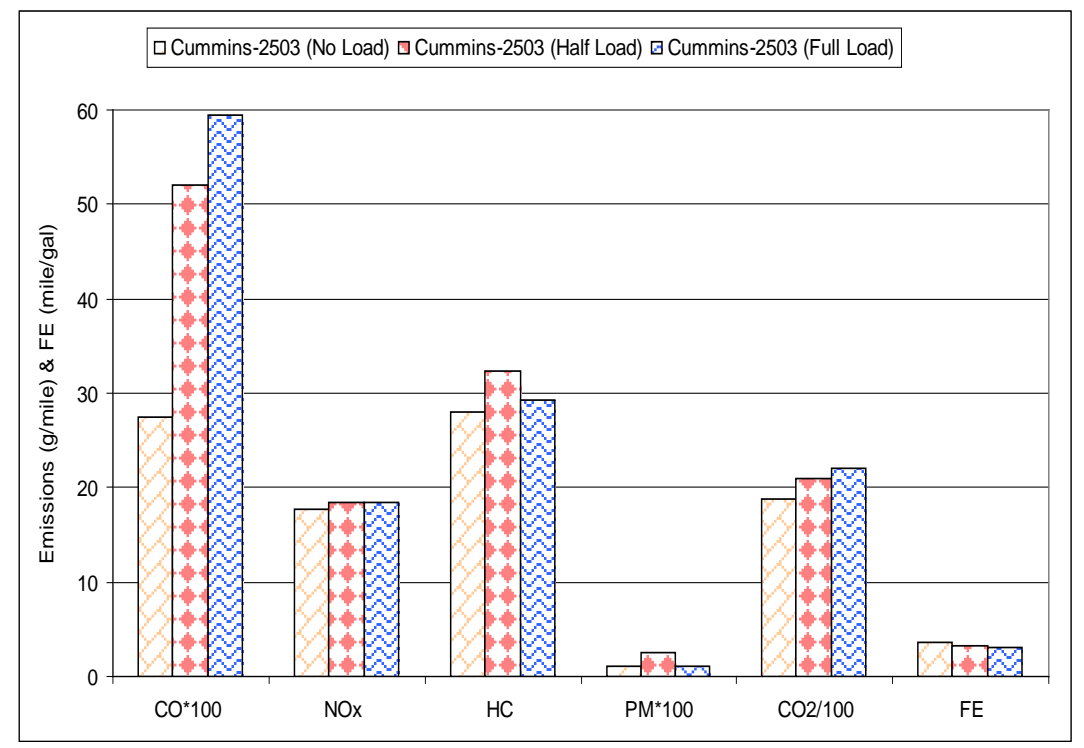

Figure 35: Weight effect on the third Cummins bus on the Braunschweig Cycle

The weight effects on emissions and FE from the retrofitted diesel bus on the OCTA, the Paris, and the Braunschweig cycles are presented in Figure 36Figure 36, Figure 37Figure 37, and Figure 38Figure 38, respectively. $\mathrm{CO}_{2}$ emissions from this bus increased with increasing weights on all cycles. Consequently, FE of this bus decreased with increasing test weights on all cycles. HC emissions from this bus at full load were higher than those at no load on the Paris and the Braunschweig cycles but did not change on the OCTA Cycle. Mixed patterns have been observed for NOx from this bus. NOx emissions at full load on all cycles were higher than those at no load. However, no patterns have been observed for NOx between half and full load test weights. CO emissions were higher at full load than those at no load test weights. PM emissions from this bus were low and did not follow any trend with test weights. 


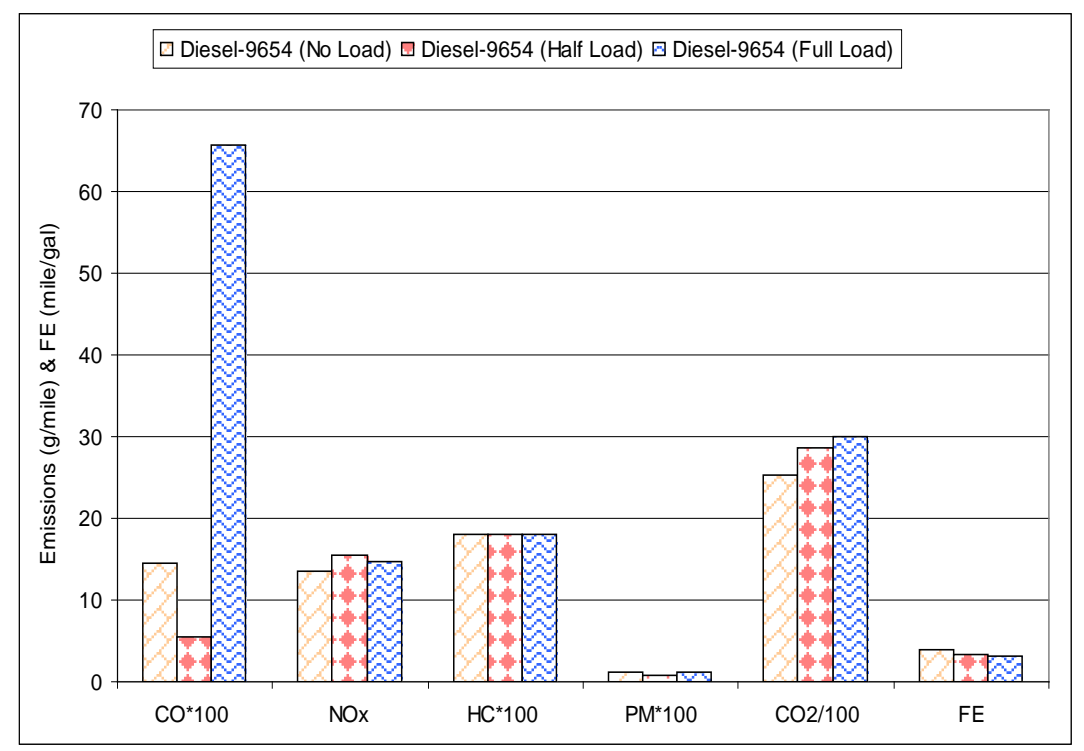

Figure 36: Weight effect on the second diesel bus on the OCTA Cycle. Note that CO and PM scales were increased a 100 fold while $\mathrm{CO}_{2}$ scale was decreased a 100 fold.

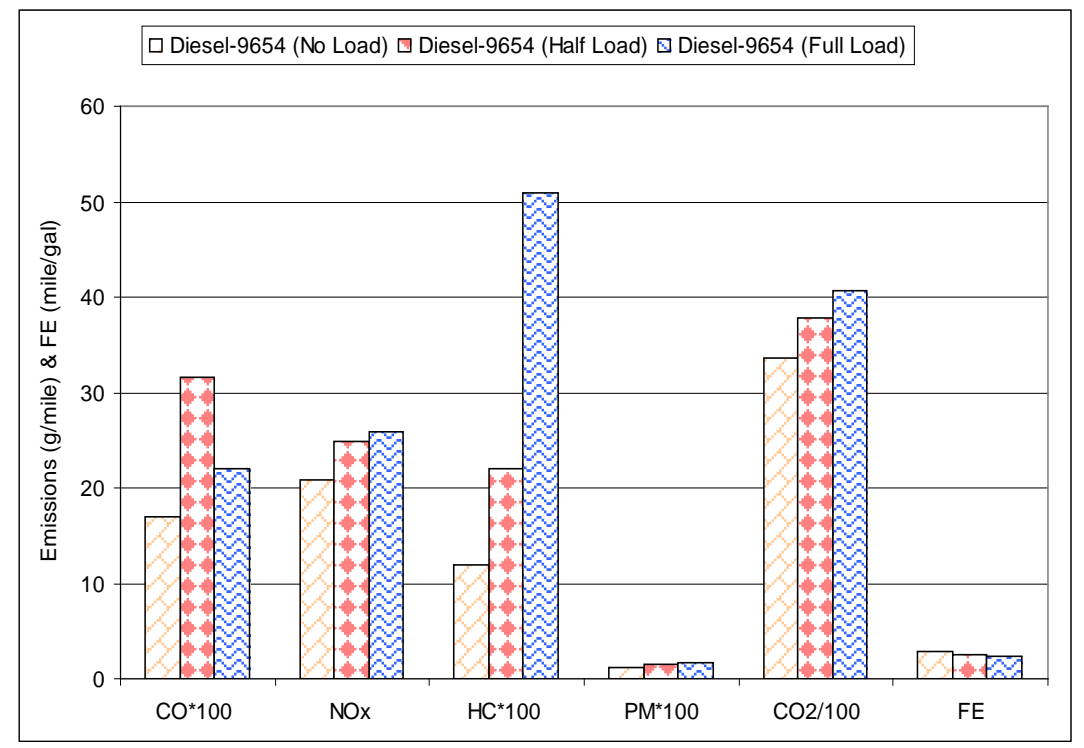

Figure 37: Weight effect on the second diesel bus on the Paris Cycle 


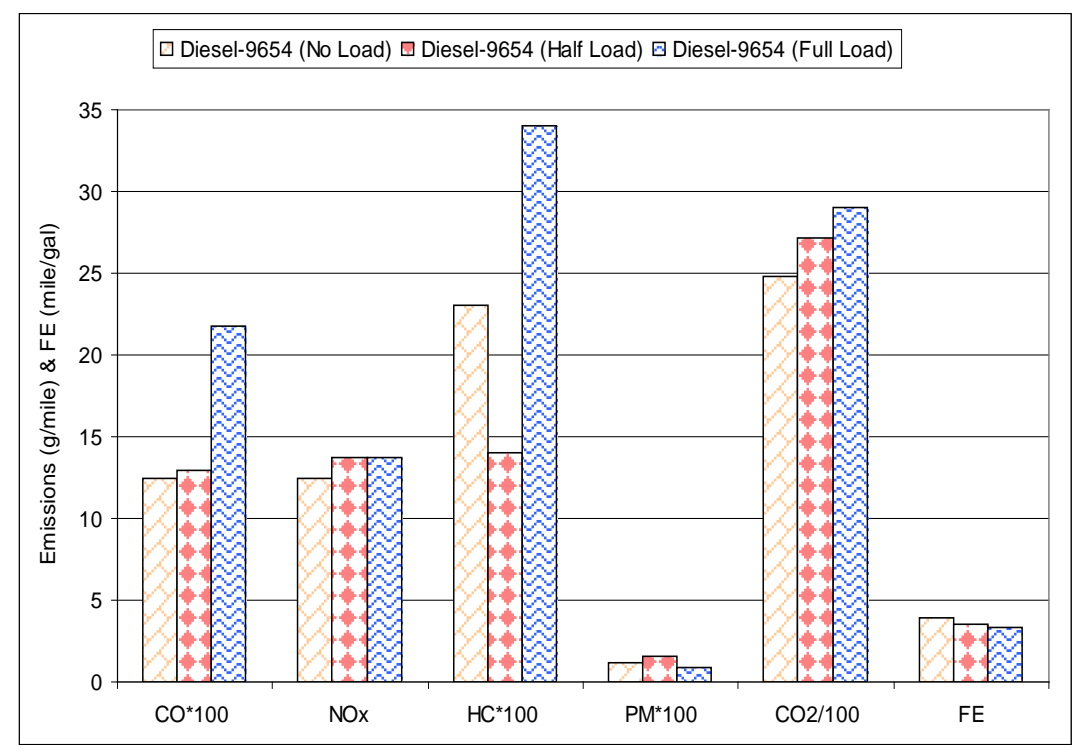

Figure 38: Weight effect on the second diesel bus on the Braunschweig Cycle

\section{FUEL ECONOMY}

FE data from the John Deere buses, Cummins buses, and the Retrofitted diesel buses are | presented in Figure 39Figure 39, Figure 40Figure 40, and Figure 41Figure 41, respectively. FE from these buses was high on the high speed cycles and low on the slow speed cycles. The NYBus Cycle exhibited low FE from these buses while the Arterial and the Commuter cycles showed high FE. FE from John Deere buses was the highest on the Commuter Cycle (6.07 mile/gal) from the third bus while the same bus on the NYBus Cycle exhibited the lowest FE (1.28 mile/gal). For Cummins buses, FE was the highest on the Commuter Cycle (5.23 mile/gal) from the third bus while the same bus on the NYBus Cycle exhibited the lowest FE (1.24 mile/gal). The second diesel bus exhibited the highest FE on the Commuter Cycle (5.29 mile/gal) while FE was the lowest on the NYBus Cycle (1.13 mile/gal) from the first bus. 


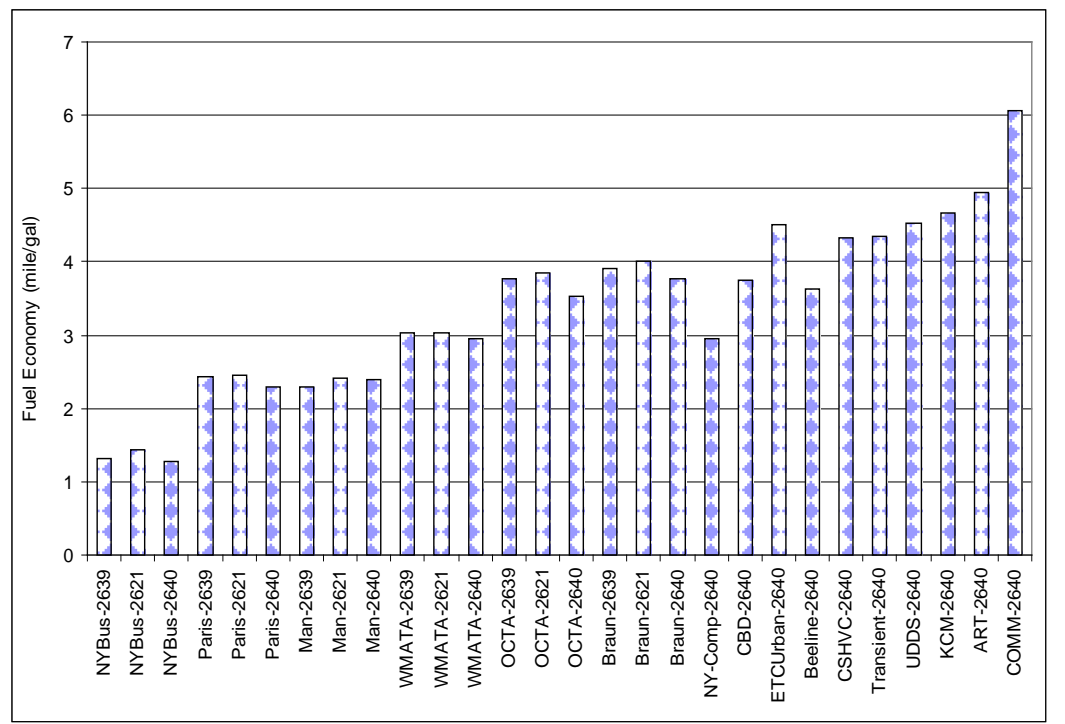

Figure 39: Cycle averaged FE from John Deere natural gas buses (mile/gal)

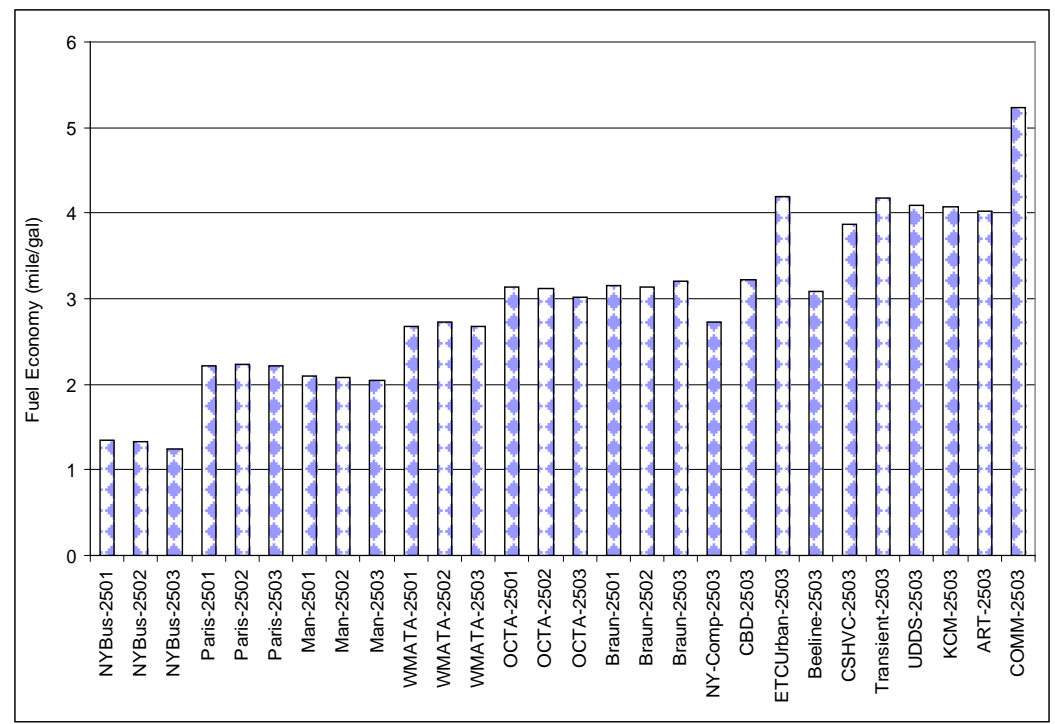

Figure 40: Cycle averaged FE from Cummins natural gas buses (mile/gal) 


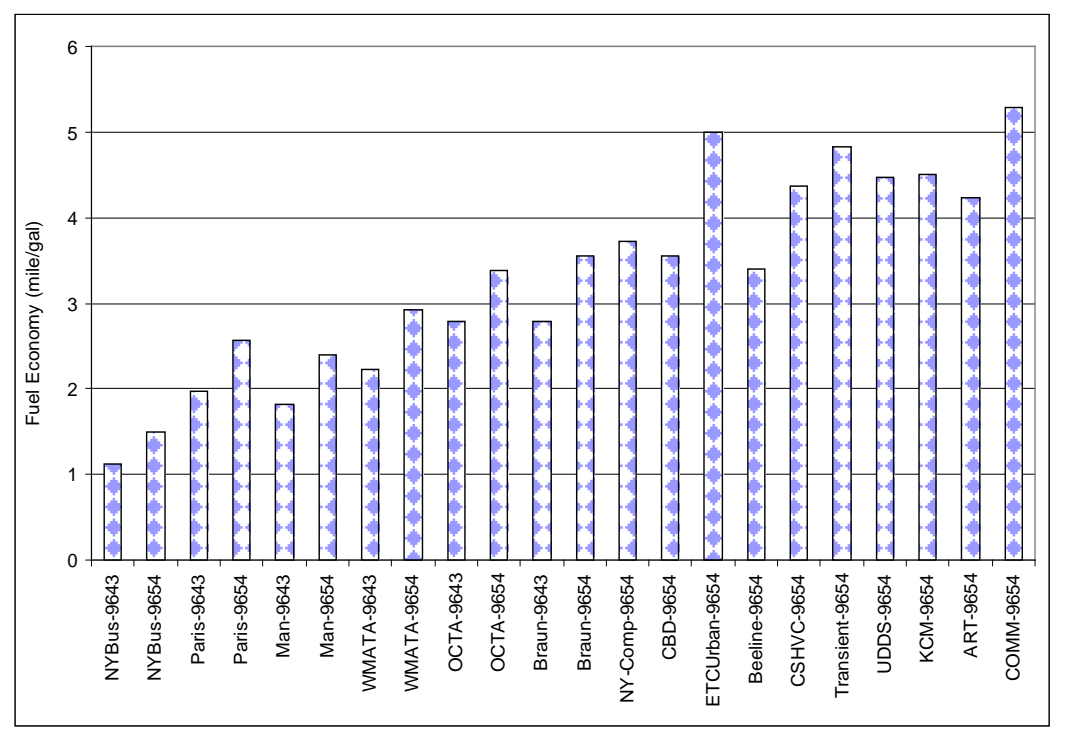

Figure 41: Cycle averaged FE from retrofitted diesel buses (mile/gal)

\section{METHANE AND NON-METHANE HYDROCARBONS (NMHC) EMISSIONS}

Exhaust samples from the natural gas buses were captured in sample bags, transported to WVU, and analyzed for methane $\left(\mathrm{CH}_{4}\right)$ and NMHC emissions. A Varian 3600 Gas Chromatograph with a Flame Ionization Detector (FID) was used for methane and NMHC speciation. In this analysis total hydrocarbon (THC) concentration was measured using the FID while methane fraction of THC was determined using the Varian Gas Chromatograph.

Cycle averaged methane and NMHC from John Deere and Cummins natural gas buses are presented in Figure 42Figure 42 and Figure 43Figure 43, and Figure 44Figure 44 and Figure 45Figure 45, respectively. Methane and NMHC values on some test runs did not satisfy the quality assurance/quality control (QA/QC) and hence, have not been reported in this analysis (see Figure 42Figure-42, Figure 43Figure-43, Figure 44Figure-44, and Figure 45Figure 45).

Methane emissions dominated the THC emissions from these buses. Methane from John Deere and Cummins buses constituted about $90 \%$ of THC emissions and NMHC constituted about $4.5 \%$ of THC, on average. Low speed cycles exhibited high distancespecific methane and NMHC emissions while high speed cycles exhibited low distancespecific emissions of these pollutants. Methane from John Deere buses varied from 7.29 
$\mathrm{g} / \mathrm{mile}$ on the Arterial Cycle to $51.88 \mathrm{~g} / \mathrm{mile}$ on the NYBus Cycle. Methane, from Cummins buses, varied from $12.74 \mathrm{~g} / \mathrm{mile}$ on the Arterial Cycle to $77.13 \mathrm{~g} / \mathrm{mile}$ on the NYBus Cycle. NMHC varied from $0.31 \mathrm{~g} /$ mile on the KCM Cycle to $2.93 \mathrm{~g} / \mathrm{mile}$ on the NYBus Cycle for John Deere buses while from Cummins buses NMHC varied from 0.75 $\mathrm{g} / \mathrm{mile}$ on the Arterial Cycle to $6.4 \mathrm{~g} /$ mile on the NYBus Cycle.

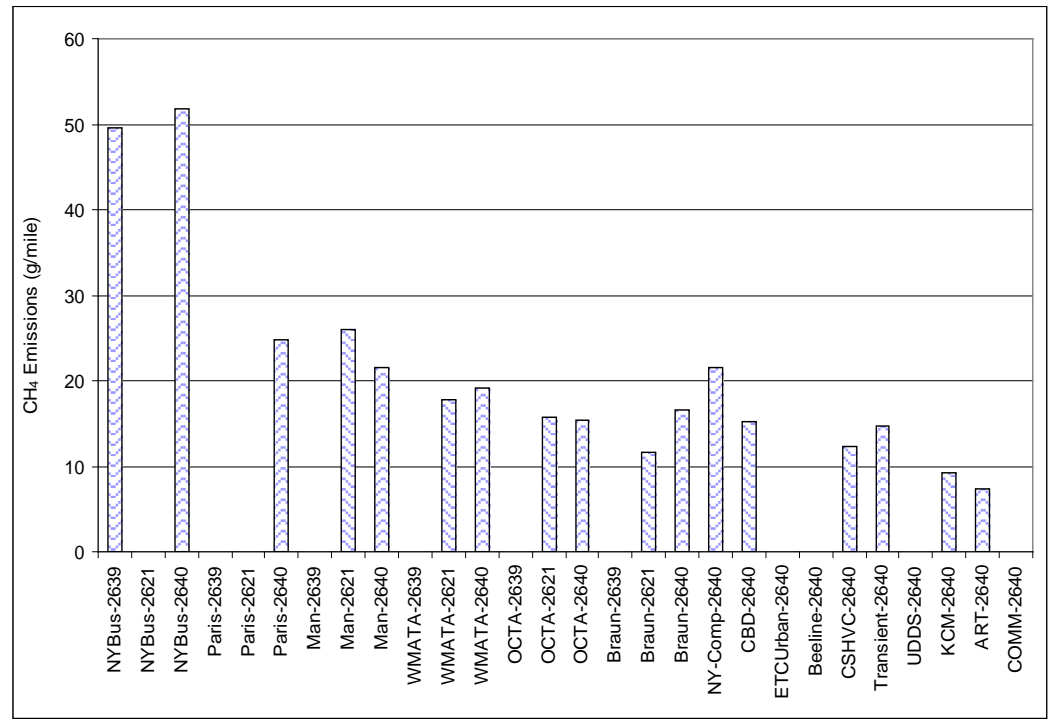

Figure 42: Cycle averaged Methane emissions from John Deere natural gas buses 


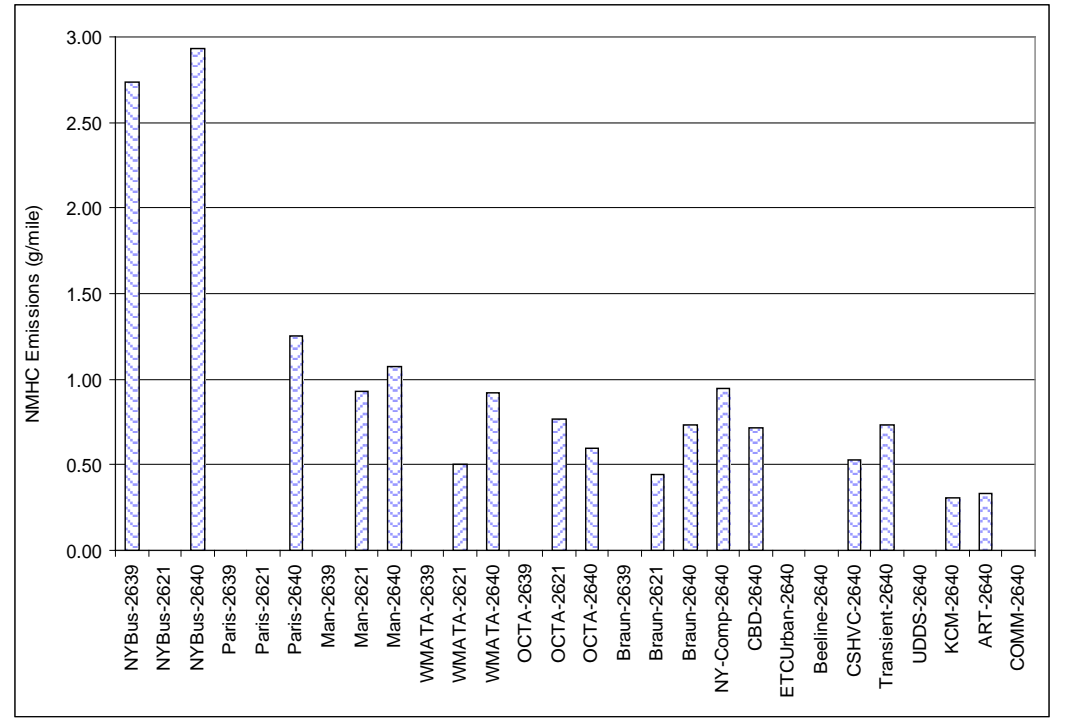

Figure 43: Cycle averaged NMHC emissions from John Deere natural gas buses

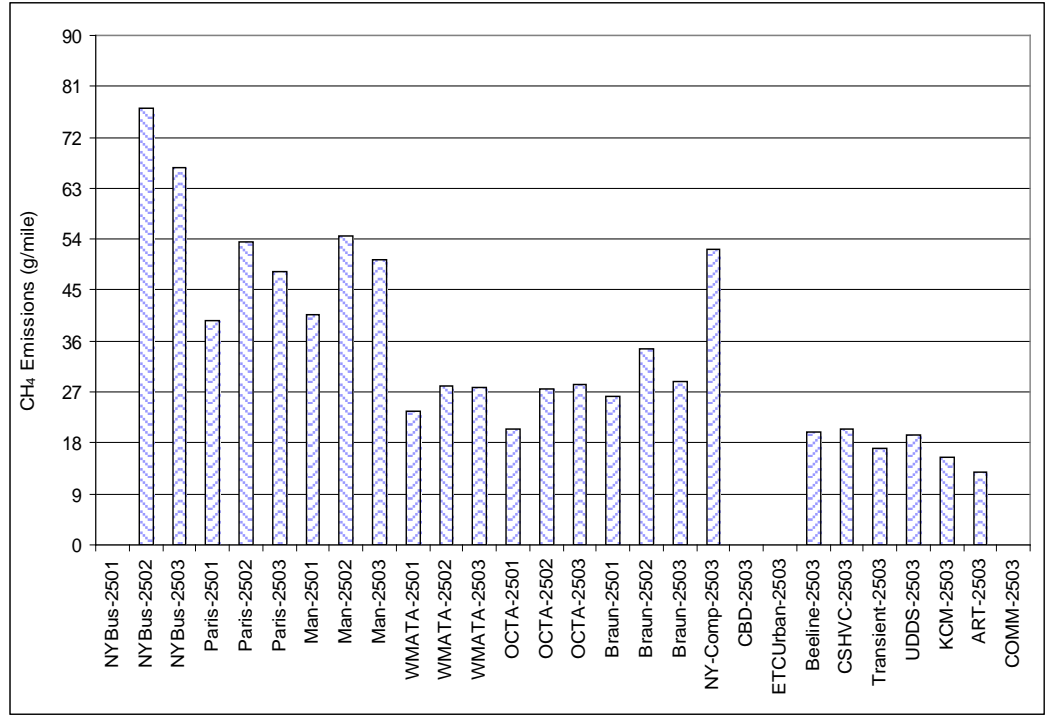

Figure 44: Cycle averaged Methane emissions from Cummins natural gas buses 


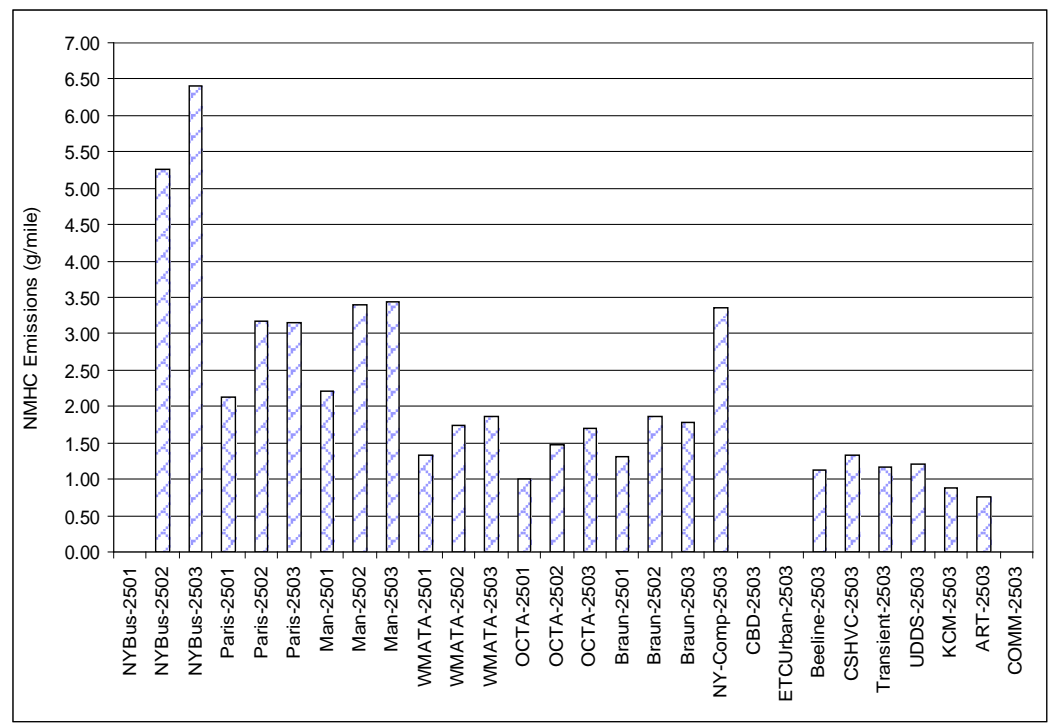

Figure 45: Cycle averaged NMHC emissions from Cummins natural gas buses

\section{$\mathrm{N}_{2} \mathrm{O}$ EMISSIONS}

Nitrous Oxide $\left(\mathrm{N}_{2} \mathrm{O}\right)$ emissions from the third John Deere and Cummins natural gas buses and the second retrofitted diesel bus were analyzed with an Inova 1302 analyzer. $\mathrm{N}_{2} \mathrm{O}$ data were collected from each bus at full and lo load condition on the OCTA, the Braunschweig, and the Paris cycles. Average emissions in $\mathrm{g} / \mathrm{mile}$ are presented in Figure 46Figure 46. $\mathrm{N}_{2} \mathrm{O}$ emissions from John Deere bus varied from $0.15 \mathrm{~g} / \mathrm{mile}$ on the OCTA Cycle at no load to $0.23 \mathrm{~g} /$ mile on the Paris Cycle at full loaded test weights. $\mathrm{N}_{2} \mathrm{O}$ emissions from Cummins bus varied from $0.10 \mathrm{~g} / \mathrm{mile}$ on the OCTA Cycle to $0.33 \mathrm{~g} / \mathrm{mile}$ on the Paris Cycle. The Retrofitted diesel bus emitted lower $\mathrm{N}_{2} \mathrm{O}$ emissions than its natural gas counterparts. Their values from the retrofitted diesel bus varied from 0.06 $\mathrm{g} / \mathrm{mile}$ on the OCTA Cycle to $0.17 \mathrm{~g} / \mathrm{mile}$ on the Braunschweig Cycle. 


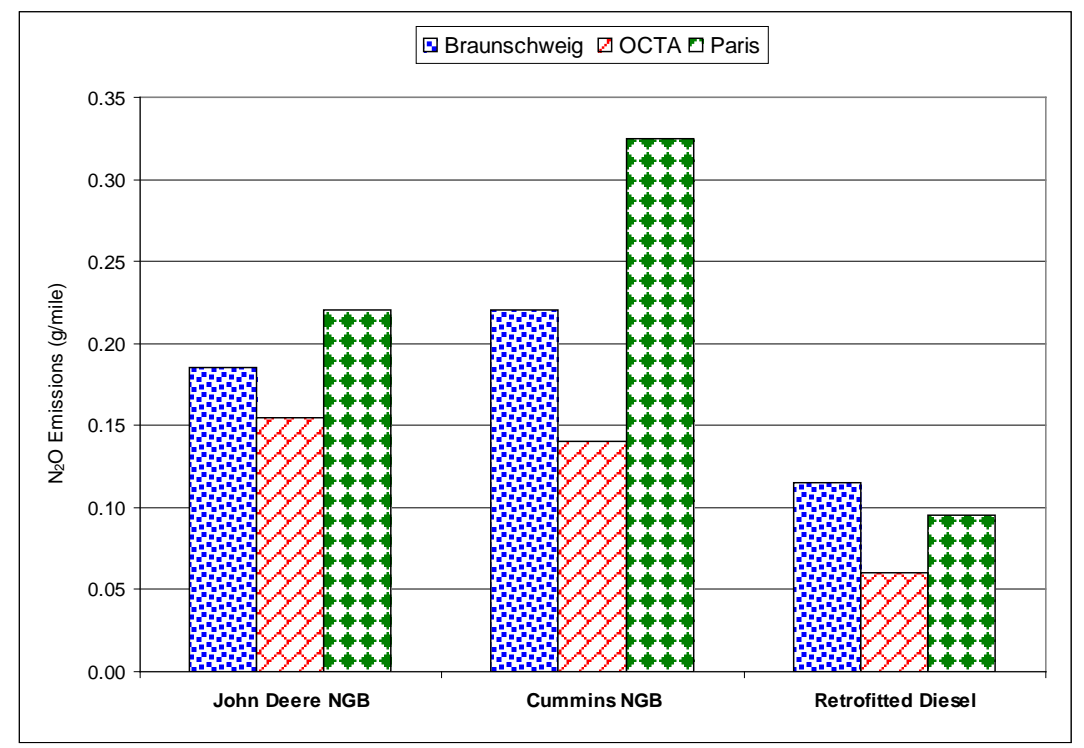

Figure 46: Average distance-specific $\mathrm{N}_{2} \mathrm{O}$ emissions from John Deere and Cummins natural gas buses and retrofitted diesel bus

\section{ALDEHYDE EMISSIONS}

Exhaust samples were collected from three buses representing John Deere, Cummins, and the DDC retrofitted bus while tested at no load and full load condition to determine the level of aldehyde compounds. Two cartridges were collected in series with a sample flow rate of 0.5 liter per minute (lpm) for each test run from every bus. Two cartridges were also collected for background analysis, but at the beginning and at the end of the testing of each bus. These cartridges were shipped to the Environment Canada for subsequent analysis. Results presented in this report are background corrected. Figure 47Figure 47 and Figure 48Figure 48 show background corrected emissions of formaldehyde, acetone, and acetaldehyde in milligrams per mile (mg/mile) from these buses at no load and full load, respectively. Figures show that formaldehyde dominates the acetone and the acetaldehyde compounds. The diesel bus, however, had negligible emissions of these species, sometimes below the background levels. 


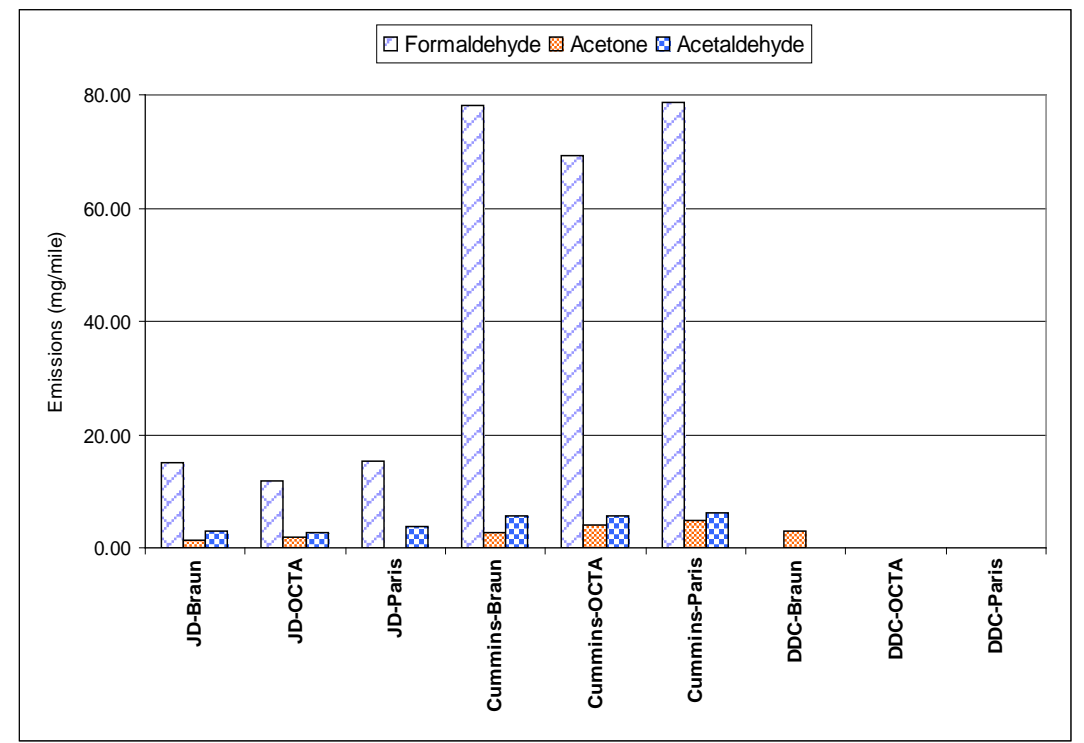

Figure 47: Background corrected formaldehyde, acetone, and acetaldehyde emissions from John Deere and Cummins natural gas buses and retrofitted diesel bus on three test cycles each tested at no-load 


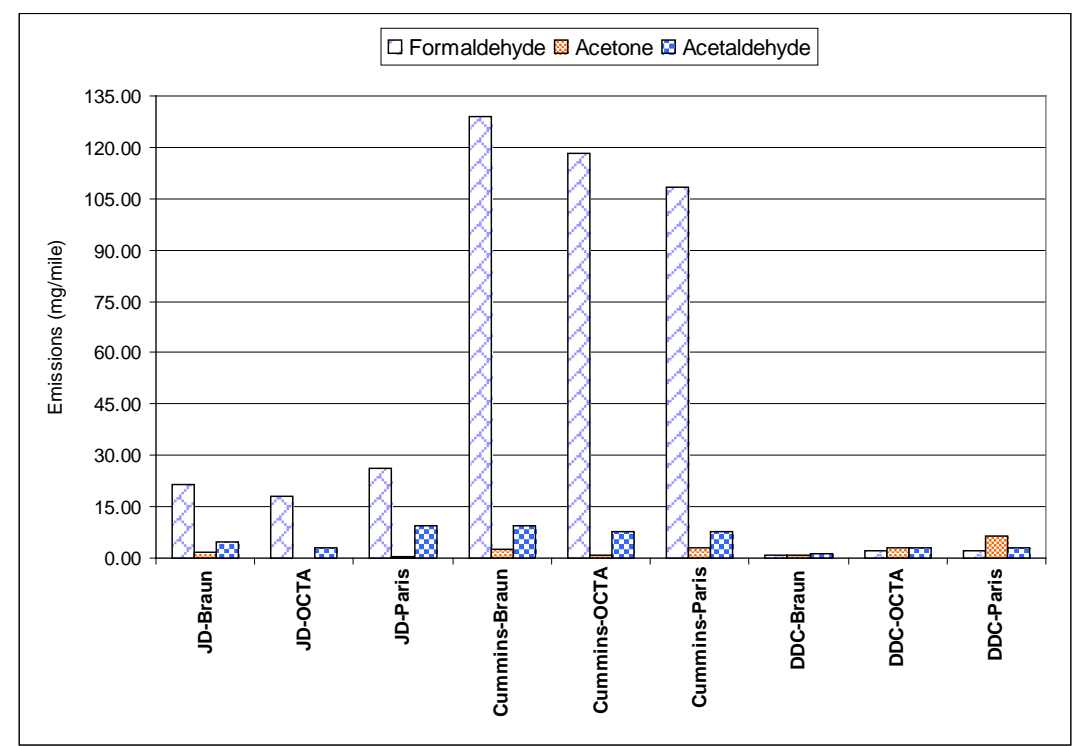

Figure 48: Background corrected formaldehyde, acetone, and acetaldehyde emissions from John Deere and Cummins natural gas buses and retrofitted diesel bus on three test cycles each tested at full-load

\section{PARTICLE SIZING RESULTS}

The particle size distributions and number concentrations were measured using a Cambustion DMS500 [20-23], which is capable of measuring multiple size bins in real time. The size range of the instrument is from $5 \mathrm{~nm}$ to $1000 \mathrm{~nm}$, and the particles having a diameter greater than $1000 \mathrm{~nm}$ are separated from the main flow using an impactor before the sampling column. The basic principle of the instrument is to load the particles with a known charge using a corona charger, and send them through a classifier which consists of a high voltage central rod and outer rings with different voltages. The particles are then deflected to the rings according to their electrical mobility, which is an indication of their size. These particles create currents when they land on the rings and these currents are converted into a distribution using an inversion matrix utilized in the software.

The instrument was connected to the main dilution tunnel to sample the flow, and $\mathrm{CO}_{2}$ trace was recorded through the DMS500 user interface as an input to the instrument for data alignment purposes with the laboratory. The particle sizing data is presented for three different cases using the third John Deere natural gas bus. The bus was exercised through the OCTA Cycle. 
The data presented for each case includes the following information:

a. The total particle number concentration (includes all size bins)

b. Contour plots of all the size bins through the test cycle with $\mathrm{CO}_{2}$ trace

c. The average size distribution though the cycle

d. Total number of particles emitted, calculated mass from the size distribution and the actual PM. (The mass from the size distribution was calculated using the assumptions that the particles were spherical throughout the size range and their density was $1 \mathrm{~g} / \mathrm{cm}^{3}$.)

\section{Load Effects}

The information presented in this section is for the third John Deere natural gas bus (WMATA 2640), and the bus was run through the OCTA cycle with three different test weights; unloaded (32,470lbs), half-loaded (36,970lbs), and fully loaded (41,470lbs). Multiple tests were run with each weight for repeatability check. (Note that minimum size bin of the DMS500 is $4.87 \mathrm{~nm}$.)

Table 4: Test ID and corresponding load status

Test ID Load

4658-0X Unloaded

4685-0X Half-loaded

4663-0X Fully loaded

| Figure 49Figure 49 gives the total particle number concentration throughout the cycle for the three different tests weights (First test of the repeat set given). One can observe the increase in the concentration as the test weight was increased. As the figure illustrates, the majority of the particles were below 30nm throughout the tests [24]. 


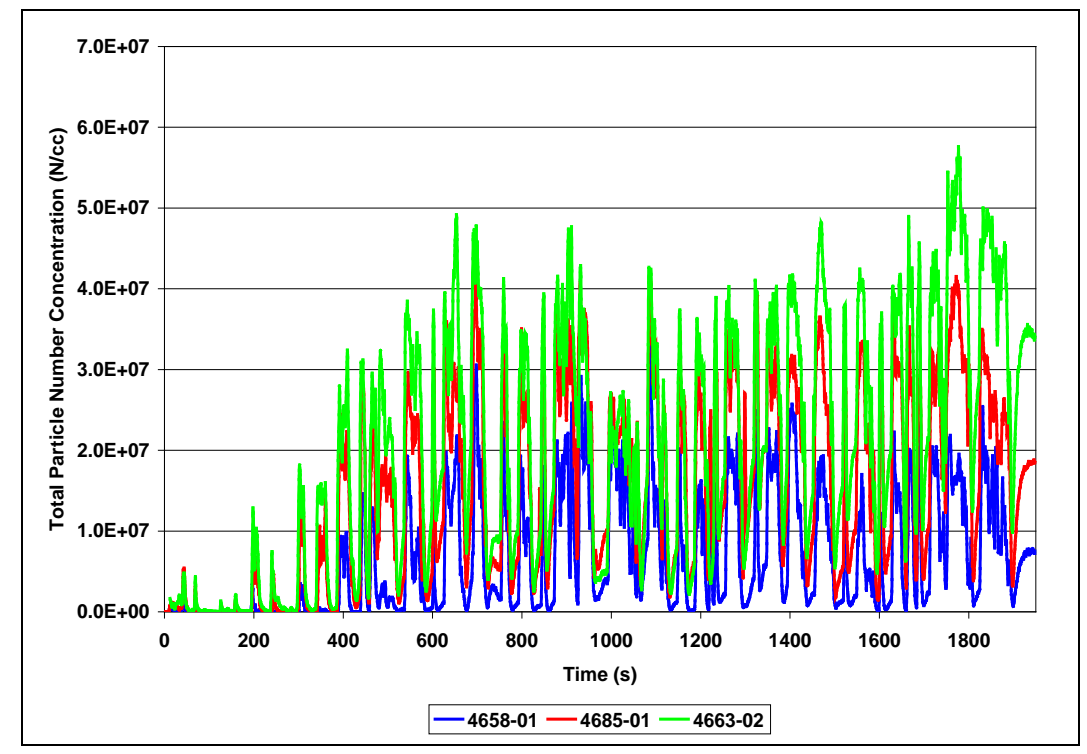

Figure 49: Total particle number concentrations for the third John Deere bus with three different test weights through the OCTA Cycle

| Figure 50Figure 50 gives the number concentration averaged size distributions for the three test weights. The peak size shifted from $6.49 \mathrm{~nm}$ to $8.66 \mathrm{~nm}$ as the test weight was increased, and total particle count increased by $109 \%$ at half load and by $188 \%$ at full

| load from the unloaded values. Figure 51Figure 51 gives the comparison between the total numbers of particles (average for repeat tests) emitted throughout the whole cycle versus the test weight. 


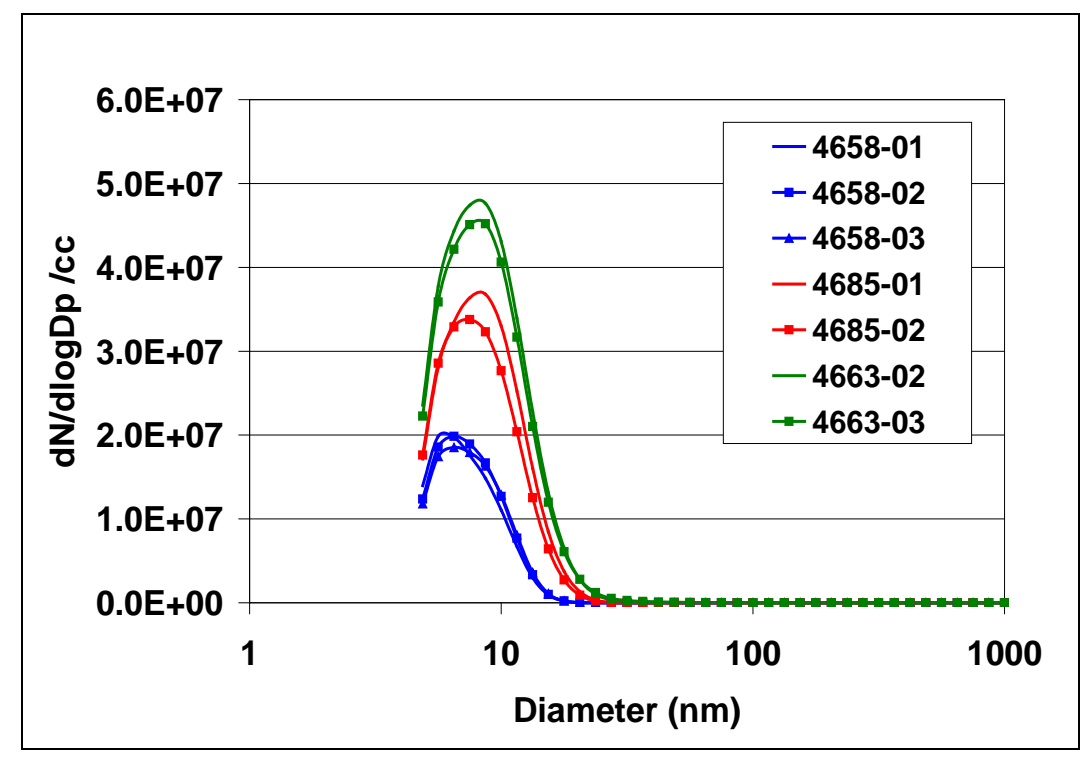

Figure 50: Average size distributions and number concentrations on the OCTA Cycle for the third John Deere bus with three different test weights

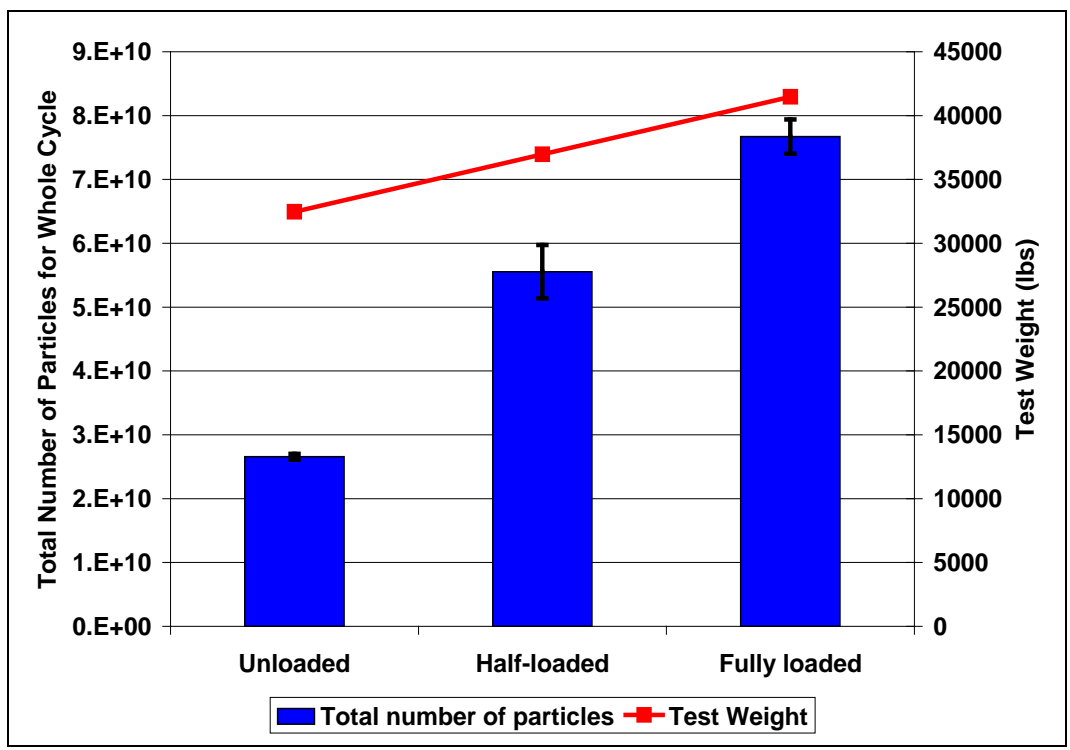

Figure 51: Total number of particles per cycle with test weight 


\section{OTHER TRANSPORTABLE LABORATORY STUDIES}

The Translab was employed in a wide variety of chassis-based heavy-duty vehicle fuel studies prior to the WMATA study which was presented in detail above. Selected prior studies are presented below.

The WVU Translab started operation in January 1992. In the first major field study, the laboratory collected gaseous and particulate emissions data from twenty six vehicles fuelled with methanol, natural gas, and diesel fuel. Comparison of regulated emissions showed that vehicles fuelled with natural gas and methanol had significantly lower PM and moderately lower NOx emissions than those from their diesel counterparts. It was also observed that emissions from these vehicles were affected by other parameters including vehicle type, weight, model year, engine type, and environmental conditions. Details of these results were published by Wang et al. in an SAE paper [25].

The Translab also tested five new buses with an aim of examining emissions from natural gas and diesel fueled buses powered by engines manufactured by Cummins Engine Company. These buses were tested on the CBD Cycle. Results published by Clark et al. [26] showed that natural gas buses exhibited very low PM emissions in comparison to the diesel L-10 buses. The results also suggested that engine maintenance was crucial if emissions were to keep at design levels.

Another study [27] was conducted to collect emissions from six transit buses using WVU Translab and the fixed base chassis dynamometer at the Colorado Institute for Fuels and High Altitude Engine Research (CIFER). The purpose of this project was to contrast the emissions performance from diesel and natural gas vehicles and to compare results from two laboratories. Three buses were powered by Cummins diesel engines while the other three buses were powered by Cummins natural gas engines. All buses were tested on the CBD Cycle. It was found that NOx and PM emissions from natural gas buses were substantially lower than those from the diesel buses. It was also observed that NOx and PM emissions from the two laboratories agreed closely for equivalent driving style, but that driving style had an impact on emissions.

In two separate studies [28-29] in 1998-1999, the Translab was used to test transit buses and trucks fueled with Malaysian Fischer-Tropsch gas-to-liquid fuel, Mossgas synthetic diesel, California diesel, and a 50/50 blend of Mossgas synthetic and regular diesel. These studies had the objectives of testing the viability and emissions performance of synthetic fuel on six transit buses and class 8 tractor trucks. Three transit buses without catalytic converters exhibited about 5\% lower NOx, and 20\% lower PM when operated with Mossgas synthetic diesel in comparison to regular diesel. The synthetic diesel performed better on three buses equipped with catalytic converter, exhibiting $8 \%$ lower NOx, and 31\% lower PM in comparison to regular diesel. The class 8 tractor fueled with Malaysian Fischer-Tropsch gas-to-liquid fuel showed 11\% lower NOx, and 12\% lower PM than when operated with California diesel. These studies concluded that fuels from non-petroleum sources offered environmental advantages in typical line haul and city transit applications. 
In a 1999-2000 study [30] the Translab was used to collect gaseous and particulate emissions data from twenty over the road tractors powered by DDC series 60 diesel engines. These vehicles were operated in four groups to asses the benefits of ARCO ECD fuel and of Johnson-Matthey CRT and Engelhard DPX exhaust particulate filter system on emissions, in comparison to commercially available California (CARB) diesel. Two test schedules, the 5 mile route and the CSHVR were employed. The test results indicated that ARCO ECD exhibited about 20\% lower NOx emissions, on average, than those associated with CARB diesel. The particulate filtration systems were effective in significantly reducing the PM level. They also reduced the bulk of CO and HC emissions from these vehicles. The study concluded that a strategy that combined PM filters with clean diesel was effective to reduce NOx and eliminate most of the mass of other regulated emissions through oxidation. The study was significant because it pioneered the use of exhaust filtration with ultra low sulfur diesel (ULSD) in a real-world fleet.

In another reported study by Chatterjee et al. [31], the Translab in 1999-2000, was employed in testing of on-road heavy-duty vehicles from eight diesel engine fleets in Southern California to examine the emissions reductions due to the use of ULSD and the installation of continuously regenerated particulate filters. Five test schedules including the CSHVR, the CBD, the 5 mile route, and the Orange County Garbage Truck Cycle were employed. The study observed successful continuous operation of the catalytically regenerated filters in these vehicles for more than six months. The particulate system was also successful in reducing CO, HC, and PM by more than $90 \%$ in the vehicle exhaust. The study did not observe ant fuel economy penalty as a result of the particulate system retrofit.

Data from Translab studies were used extensively in reports [32, 33] prepared by the National Renewable Energy Laboratory (NREL) to describe the performance of heavyduty vehicles in field applications. These reports typically combined maintenance, operation and fuel economy data gathered by NREL and by the Battelle Memorial Institute with emissions data gathered by West Virginia University.

\section{SUPPORTING STUDIES}

West Virginia also conducted supporting studies to advance the understanding of alternative fuels applications. These studies did not employ the Translab directly, but were implemented on test stands with separate exhaust dilution and analyzers. Studies were aimed at both natural gas and liquid fuel applications. While most of the programs were geared to the use of a single engine, the Diesel Emissions Control - Sulfur Effects (DECSE) [34] activities conducted by WVU involved four engines with extended operation to clarify the effects of fuel sulfur on advanced diesel engine aftertreatment devices.

A supporting study, in 1992-93, examined the bi-fuel capability on a 1992 Saturn 1.9 liter 4-cylinder dual overhead cam engine [35]. The engine was instrumented to operate on both gasoline and natural gas. The study had the objective of recovering power loss 
associated with natural gas operation and avoiding knock during gasoline operation. Most bi-fuel engine designs suffered in natural gas mode because they accommodated gasoline knock limits with low compression ratio selection. The study observed that the dual fuel controller with closed loop control worked well and demonstrated significant improvement in emissions. $\mathrm{NOx}, \mathrm{CO}_{2}$, and $\mathrm{HC}$ emissions were reduced when the engine was operated on natural gas. However, natural gas operation exhibited higher power loss at wide open throttle (WOT) than that from gasoline operation, especially at high speeds. The researchers believed that a combination of poor mixing and intake manifold misdistribution might have been the cause of additional power loss at WOT. The study recommended the use of a new injection point to improve mixing of air and natural gas for achieving the best possible power at WOT for natural gas operation. A second natural gas study was conducted using Hercules engines, and a closed loop control strategy was proposed, using a wide range oxygen sensor in the exhaust [36, 37].

In another study in 1998-99 by Park et al. [39], WVU researchers examined the operation of a compression ignition engine with a hydraulically actuated electronically controlled unit injection system (HEUI) for dual fuel application. Diesel pilot injection was employed using a Navistar T444E turbocharged V8 engine which was converted to operate in dual fuel mode while retaining the HEUI system for diesel pilot injection. The study observed significant reductions of NOx and PM and slight increase in thermal efficiency when the engine was operated in a dual fuel mode. However, CO and THC increased substantially over the diesel-only operation. The researchers noted an increase in $\mathrm{HC}$ and $\mathrm{CO}$ emissions that could be reduced by exhaust aftertreatment systems.

In a 2000-2001 study by Wayne et al. [40] the WVU test cell was used to quantify diesel emissions with a split exhaust configuration. The WVU researchers performed evaluations on diesel oxidation catalyst (DOC) and lean-NOx catalysts for the first 250 hours of catalyst operation. The study was part of the DECSE program to determine the impact of diesel sulfur levels on emission control systems. In this experiment catalyst aging was achieved by splitting the engine exhaust into two streams so that approximately half the total exhaust was flown through the DOC and the other half though lean NOx catalyst. The catalysts were evaluated for CO, HC, and PM reduction efficiency during four steady state operating mode and the heavy-duty federal test procedure (FTP). Results showed that the DOC significantly reduced PM by about 35$40 \%$. Fuel sulfur did not affect the performance of the DOC in reducing PM. After aging the catalysts were found to be more efficient in reducing soluble organic fraction of PM while CO reduction efficiency was reduced by about $10 \%$, which was independent of fuel sulfur content. Lean NOx catalysts, on the other hand, reduced NOx emissions by about $20 \%$. Catalysts aging and fuel sulfur did not affect the NOx reduction efficiency of the catalysts.

Another effort supporting the comparison of conventional and alternative fuels addressed the speciation of exhaust HC constituents. Gas chromatography was employed to name species from both natural gas and diesel exhaust [41]. Speciation was extended to include exhaust particle size characterization, using electrical size classification [38]. 


\section{LOW EMISSIONS LABORATORY DEVELOPMENTS}

A major task in the last two years of the Translab program was to reconfigure the laboratory to be compliant with 2007 EPA emissions measurement hardware definitions and procedures. While this hardware and these procedures are intended for engine test cell use, they can be applied to chassis dynamometer work as well. The use of exhaust gas filtration has led to more than a tenfold reduction in PM levels for engines manufactured in 2007 and beyond. These engines, as well as low emissions alternative fuel engines, necessitated the adoption of improved measurement techniques. The reconfiguration involved the design and construction of a new full scale tunnel sampling system and emissions measurement equipment, fitted into a container rather than a trailer. The sections below describe modeling undertaken in support of this design, followed by an account of the low emissions measurement system.

\section{LOW EMISSIONS TUNNEL MODELING}

\section{Overview}

Exhaust from a vehicle under test is diluted using a subsonic control volume sampling (CVS) system. Gaseous emissions are sampled from the primary dilution tunnel and analyzed by instruments capable of continuous measurement. Particulate Matter (PM) is

| diluted twice before being collected on a particulate filter. Figure 52Figure 52 shows a high level diagram of a Simulink ${ }^{\circledR}$ model for the WVU 2007 PM emission sampling system. Figure 53Figure 53 shows the model details of the $2^{\text {nd }}$ tunnel and PM filter.

Formatted: Font: Times New Roman, 12 pt

Formatted: Font: Times New Roman, 12 pt 


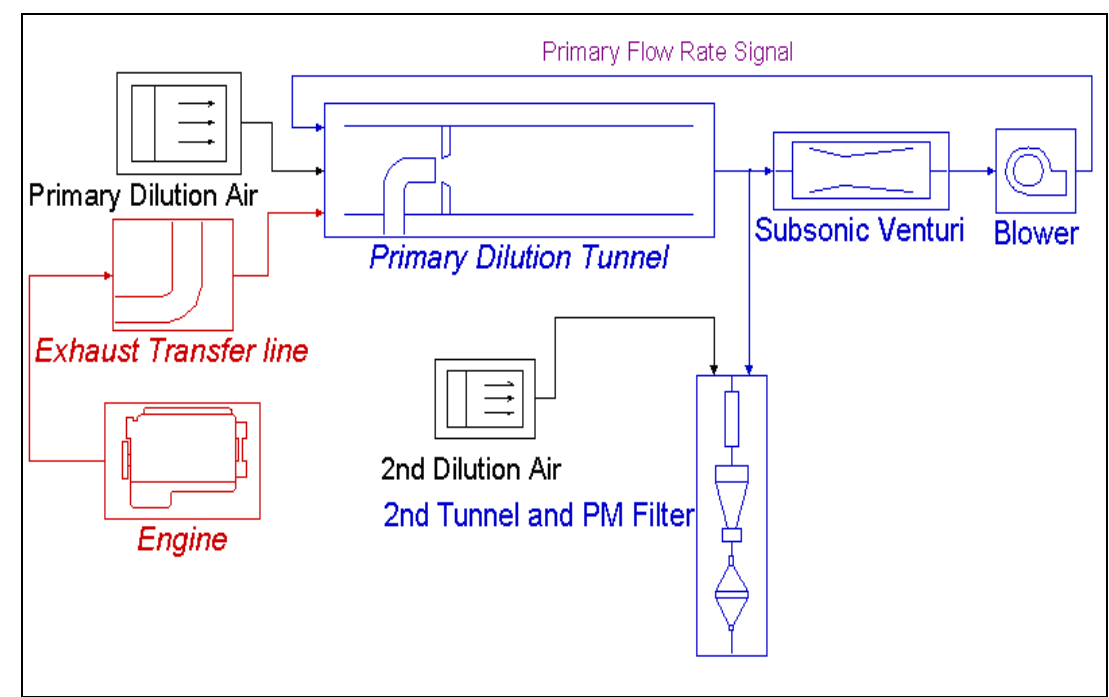

Figure 52: Simulink ${ }^{\circledR}$ Model of PM Sampling System-Highest Level

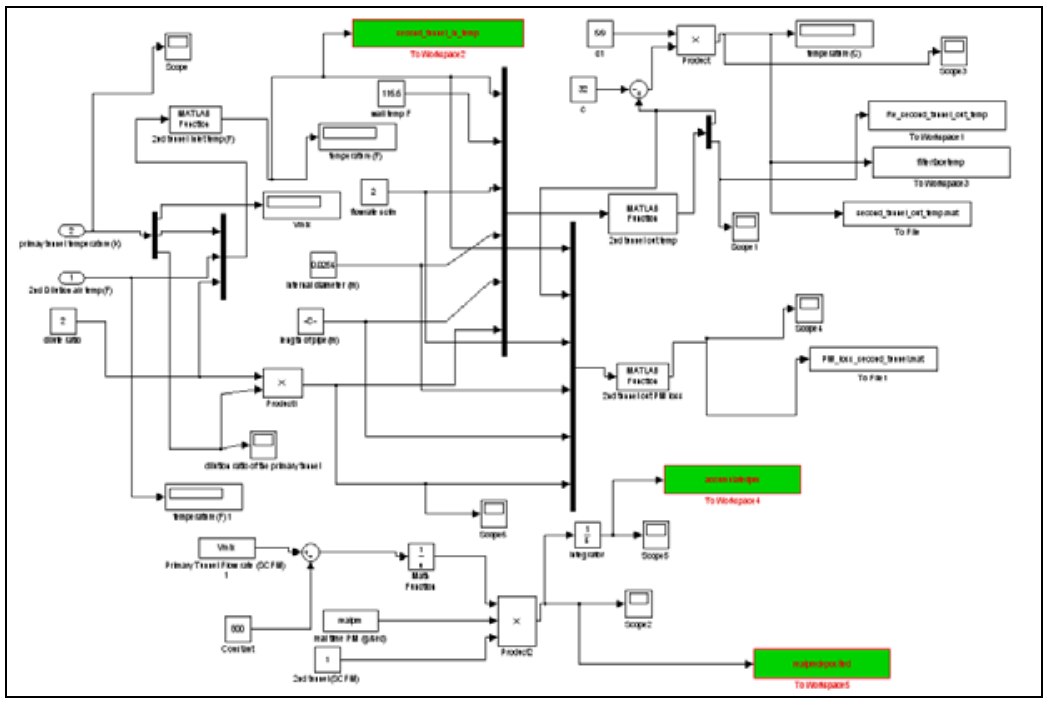

Figure 53: Sub-Level View of secondary tunnel and PM filter 
Modeling of the PM sampling system shown in Figure 52Figure 52 was undertaken to examine system behavior. A subsonic venturi was prescribed in the EPA 2007 emission measurement regulations. This was the basic design selected for use at WVU for 2007 compliant measurement. The completed model has been presented in detail by Wu et al. [42] and is summarized below.

Factors considered and integrated in this model were engine operating condition, exhaust composition, heat transfer, particle penetration loss, and PM filter face velocity. Real time CO emissions served as a proportional indictor of PM emissions level based upon the established correlation between the two species. The model was also validated with existing, older tunnel data to build confidence in its predictions.

Simulation Variables

A parametric study was conducted by varying engine running conditions and certain characteristic sizes of the PM measurement system. The heavy-duty engine mimicked in this model was a Cummins ISM 370 engine. To investigate the possible impact of proposed alternative PM measurement systems, ambient air temperature was set to $27^{\circ} \mathrm{C}$. Filtered dilution air temperature for the secondary tunnel was set to $38^{\circ} \mathrm{C}$. This value is required to be equal to or greater than $15^{\circ} \mathrm{C}$ by the CFR. The tunnel's wall material was selected as stainless steel AISI 304 with density $7900 \mathrm{~kg} / \mathrm{m}^{3}$ and heat capacity $477 \mathrm{~J} /(\mathrm{kg} \cdot \mathrm{K})$. Mineral fiber foam with conductivity $0.035 \mathrm{~W} /(\mathrm{m} \cdot \mathrm{K})$ and emittance coefficient 0.85 was used in the simulation to insulate the transfer pipe and the primary tunnel. A baseline model with the following assigned values was set up to examine the influence of variables:

Tunnel ID: $D_{t}=12.7, D_{p}=50.0, D_{s}=1.0(\mathrm{~cm})$

Tunnel length: $L_{t}=5.0, L_{p}=7.0, L_{s}=1.2(\mathrm{~m})$

Tunnel wall thickness: $\delta_{t}=2.0, \delta_{p}=5.0(\mathrm{~mm})$

Tunnel insulation thickness: $\delta_{t i}=2.0, \delta_{p i}=5.0(\mathrm{~cm})$

Initial tunnel temperature: $T_{t}=376, T_{p}=304, T_{s}=320(\mathrm{~K})$

Tunnel flow rate: $V_{p}=1.0\left(\mathrm{~m}^{3} / \mathrm{sec}\right), V_{s}=1.0($ Liter $/ \mathrm{sec})$

Secondary dilution ratio: $D R_{s}=2.0 \quad$ *suffix: $t$ (exhaust transfer pipe); $p$ (primary tunnel);

s(secondary tunnel)

Real-time data for air fuel ratio, exhaust temperature, and exhaust flow rate were recorded from a test cell engine dynamometer run of a Cummins ISM 370 heavy-duty engine. Even though this was not a 2007 engine, data recorded from its running were effective to test this system model. 
Results

The influence of the selected variables was investigated by altering variable values of the baseline model individually in the following categories. Effects of variables on the filter face temperatures and PM diffusion losses were investigated. Relevant variables included ambient temperature, transfer pipe size, primary tunnel size, primary tunnel flow rate, secondary tunnel size, secondary tunnel flow rate, pipe and tunnel insulations, secondary tunnel wall temperature and engine running condition. Effects of total dilution ratios on the cumulative filter PM mass were also examined. All variables other than the variable concerned were the same as the baseline model if not specifically mentioned. The effect of secondary tunnel is presented below as an example of how the variables were investigated with this model.

\section{Effect of Secondary Tunnel Flow}

The maximum flow rate for the secondary tunnel was around 1.2 liters per second when a $47 \mathrm{~mm}$ filter was modeled. Simulations showed how various secondary tunnel flow rates acted on the filter face temperature. The secondary dilution ratio was a constant of 2.0. The overall dilution ratios for the secondary flow were always twice the dilution ratios for the primary flow.

| Figure 54Figure 54 shows that the maximum filter face temperature drops first, then goes up with the increasing secondary flow rate, while the minimum filter face temperature rises first then goes down from low to high secondary flow rate. At low flow rates, the secondary tunnel was at a laminar condition and the convection heat transfer between the tunnel wall and the exhaust was weak. As a result, the temperature of the flow did not change much. As the flow rate increased, the secondary flow transitioned to turbulent flow and the convection heat transfer became stronger. The flow's temperature then approached the wall's temperature more closely. As the secondary flow rate was further increased, the heat transfer between the tunnel wall and the mass flow was also further intensified. However, once the flow rate reached a certain point ( 0.25 liters per second), the increasing rate of the flow mass became higher than the increasing rate of heat transfer, leading to the maximum and minimum. 


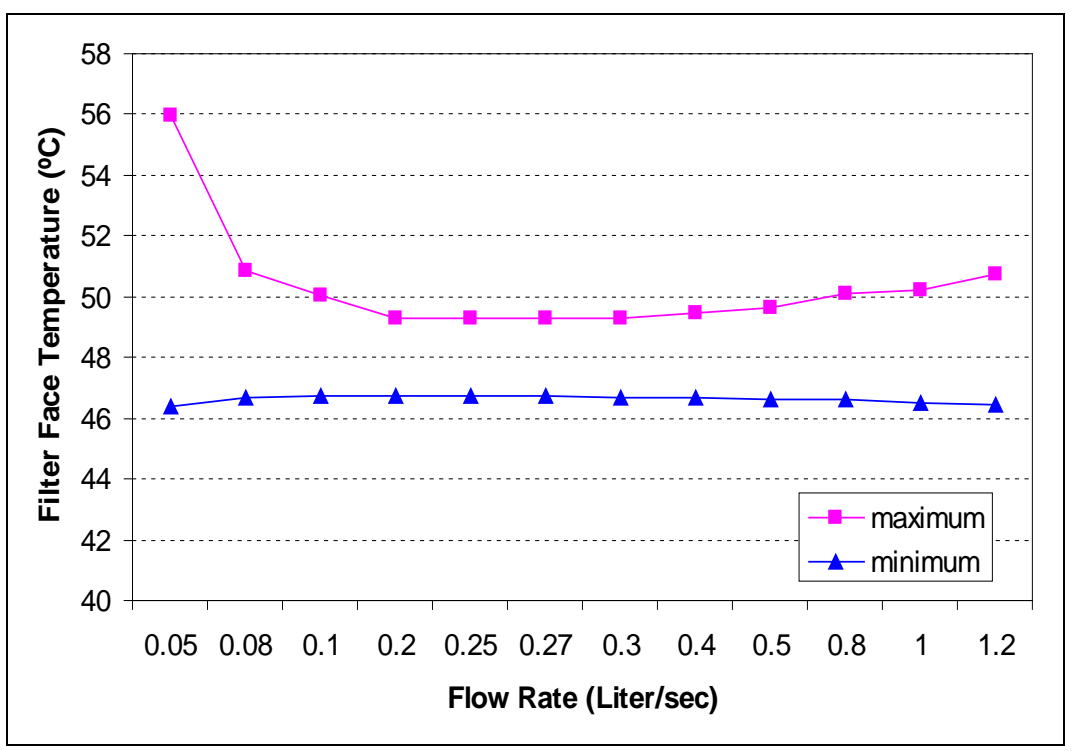

Figure 54: Maximum and minimum filter face temperatures with different secondary tunnel flow rates

Model Investigation Conclusion

It was impossible to investigate every trend and combination. However, it was still important to change the values of the variables individually to understand their influence for the design of a compliant 2007 system.

The analysis of the simulation results of this model revealed:

- The simulated venturi and filter face temperatures were compared with real-world measured ones for a pre-existing PM measurement system. Agreement was good and the researchers believed that it was reasonable to use this Simulink ${ }^{\circledR}$ model as an auxiliary design tool for the 2007 PM measurement system.

- There were many designs variations possible within the restriction of the EPA's 2007 regulation on PM sampling systems.

- Settings of test conditions, such as flow rate of the CVS system and wall temperature of the secondary tunnel, were critical to the test system's compliance with the 2007 standards. A test system with same geometry might or might not meet the 2007 regulations when test conditions change.

- The same initial test conditions (such as tunnel wall temperature) needed to be set for each transient test to produce consistent simulation results. 
- The secondary tunnel was responsible for most PM diffusion losses throughout the system. PM diffusion losses mainly occurred for particles with diameters less than $10.0 \mathrm{~nm}$. Under most circumstances, particles of such size accounted for a negligible weight fraction of total PM mass. In this way filter mass measurement was not compromised, but particle size distributions measured at the filter face would reflect losses.

- Length of transfer pipe had little effect on the filter face temperature. However, in order to reduce heat and PM diffusion loss, the transfer pipe needed to be as short as possible.

- Insulation for the transfer pipe and the primary tunnel had little effect on the filter face temperature and PM diffusion losses, but it could reduce the system's heat loss and is highly recommended.

- If the stabilized filter face temperatures for the engine running at full power and running at idle were with the specification of the 2007 standard, it was likely the filter face temperature would be within the restriction of the 2007 regulations for a transient cycle test.

\section{EMISSIONS MEASUREMENT CONTAINER}

\section{Primary Dilution System}

The researchers upgraded the laboratory at the Engines and Emissions Research Laboratory (EERL) to meet US EPA 2007 specifications as outlined in 40 CFR Parts 86 and 1065. This laboratory acted as a pilot for the improvements in measurement accuracy of the Translab. Also a clean weighing enclosure was established with stabilized temperature and humidity to weigh PM filters, rather than characterize PM mass in the field.

Two separate 20-inch primary dilution tunnel systems were installed at the EERL. These tunnels were used to verify the design for the transportable laboratory system. Each tunnel system was constructed of 316 stainless steel and consisted of an entrance region, a mixing region, a sampling region, a plenum, and two subsonic venturies.

A system for calibration of the subsonic venturi was designed and installed above the primary dilution tunnel system. The calibration tunnel was connected to the exhaust fan in a similar manner as the exit region of the subsonic venturi. NIST-traceable calibration venturies were used to calibrate the primary dilution tunnel system.

Several calibrations to determine the mass flow rate in the primary dilution tunnel were performed on the subsonic venturi using the NIST-traceable calibration venturi and appropriate ducting over a nominal range of flow rates of 1000 to $3500 \mathrm{scfm}$.

Temperature and pressure measurements, both absolute and differential, were recorded at both the inline venturi and the calibration venturi. Calculations were made in accordance 
with 40 CFR $\$ 1065.640$ to develop a curve of the discharge coefficient of the inline venturi vs. Reynolds number at the throat of the inline venturi. Multiple calibrations were required to verify equipment and ensure repeatability. The final calibration curve is shown in Figure 55.

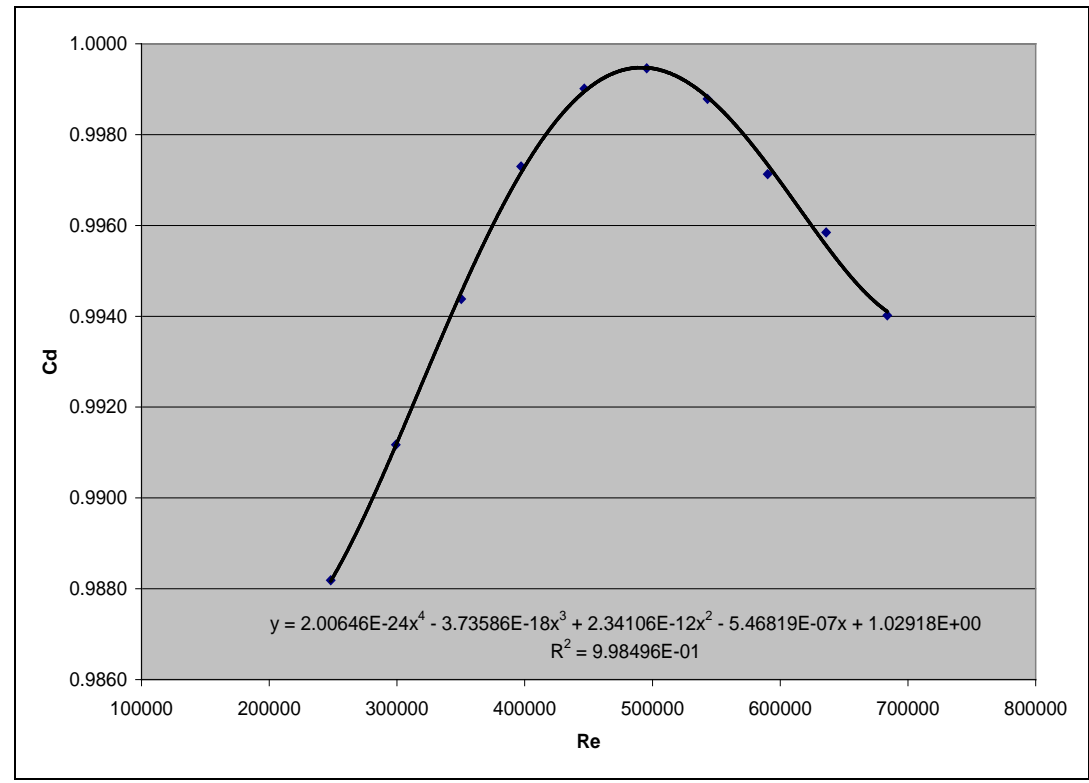

Figure 55: Inline subsonic venturi discharge coefficient vs. Reynolds number calibration curve

\section{Secondary Dilution Tunnels}

New secondary dilution tunnel systems for particulate matter collection were designed and constructed for both the engine test cell and the Translab. Each system consisted of a 1 inch heated line that served as the secondary dilution tunnel, a heated enclosure that contained plumbing, a cyclone, $47 \mathrm{~mm}$ filter holders, a bypass system, solenoid valves, mass flow controllers, and electronics. These components can be seen in the heated enclosure in Figure 56. Dilution air was introduced into the secondary dilution tunnel through a custom fitting at the inlet of the heated line. A vacuum pump was used to draw the exhaust sample through the system into the laboratory evacuation system. If necessary, conditioned secondary dilution air could be introduced into the PM sampling system at the entrance of the secondary dilution tunnel. Secondary dilution air was used to control the filter face temperature to $47 \pm 5{ }^{\circ} \mathrm{C}$ in accordance with $40 \mathrm{CFR}$ $\S 1065.140(\mathrm{e})$. 


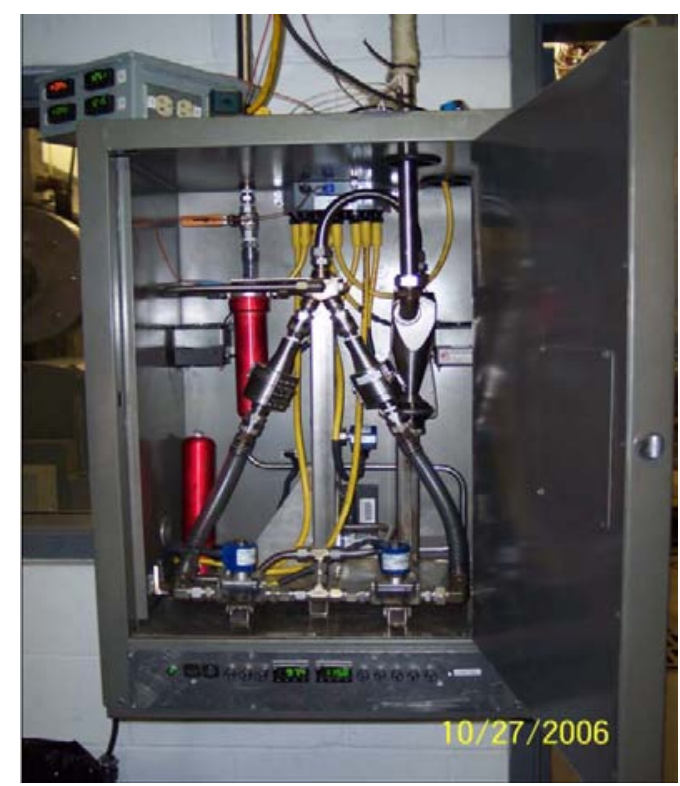

Figure 56: 2007 PM sampling system heated enclosure

\section{Gaseous Exhaust Sampling System}

The gaseous sample systems were built to satisfy the 2007 heavy-duty diesel engine emissions testing requirements as specified in 40 CFR Part 1065. The systems included the Horiba MEXA 7200D and contained high and low concentration CO non-dispersive infrared (NDIR) analyzers, a $\mathrm{CO}_{2}$ NDIR analyzer, dual chemiluminescent $\mathrm{NOx}$ analyzers, a heated flame ionization detector analyzer for $\mathrm{HC}$ measurement, and a second heated flame ionization detector analyzer for NMHC detection. The systems were designed to accommodate a 19-inch rack assembly.

The Horiba MEXA 7200D mobile emission analyze bench has been installed and calibrated in the 2007 Translab system. The electric power wiring and the electronic signal wiring have been completed. Figure 57 shows the 2007 emission test tunnels. The top tunnel was selected to be used for CNG engine emissions research while the middle tunnel was selected to be used for diesel engine emissions test. The exhaust inlet and the end of CNG tunnel needed to be sealed during diesel emissions tests. The tunnel flow rate was varied with the change of the blower's fan speed and measured by a subsonic venturi, in agreement with new emissions measurement requirements. The flow rate control hardware and software for the mobile laboratory tunnels were established. The gaseous analyzers and secondary PM system were integrated using sample ports and 
heated lines. Figure 58 shows the side view of the Translab, Figure 59 shows the inside view of the Translab from the front door, and Figure 60 shows the sample zone of the diesel tunnel. Figure 61 and Figure 62 show the rear view of the Translab and the MEXA 7200D mobile gas analyzers.

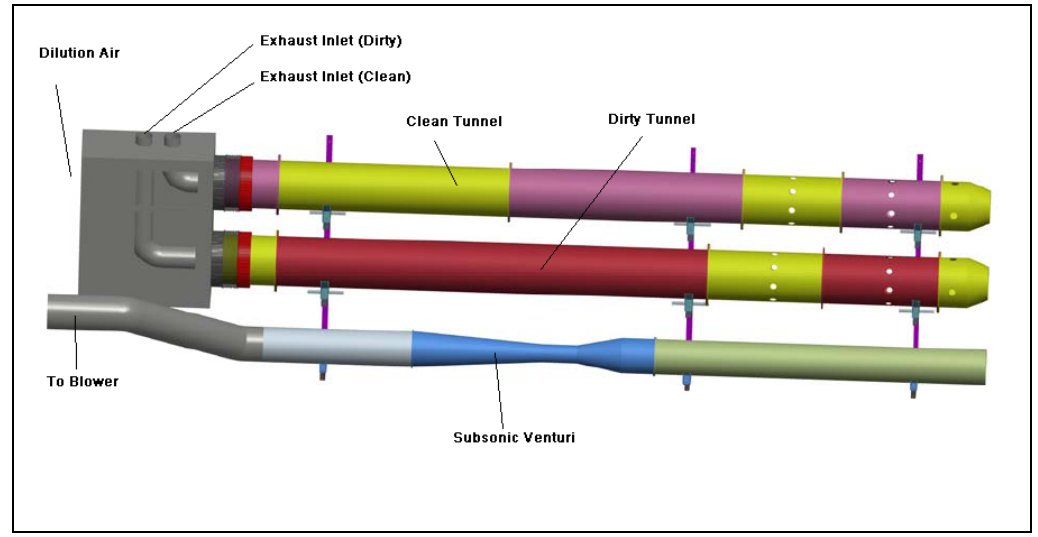

Figure 57: Schematic of laboratory emission test tunnels of the Translab

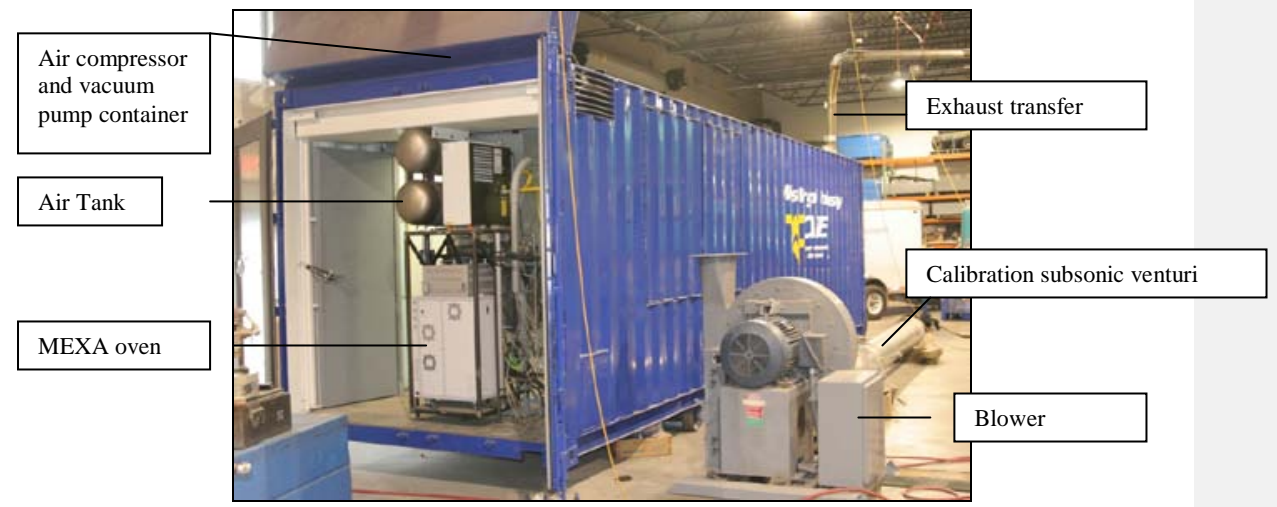

Figure 58: View of the Translab containerized emissions measurement system 


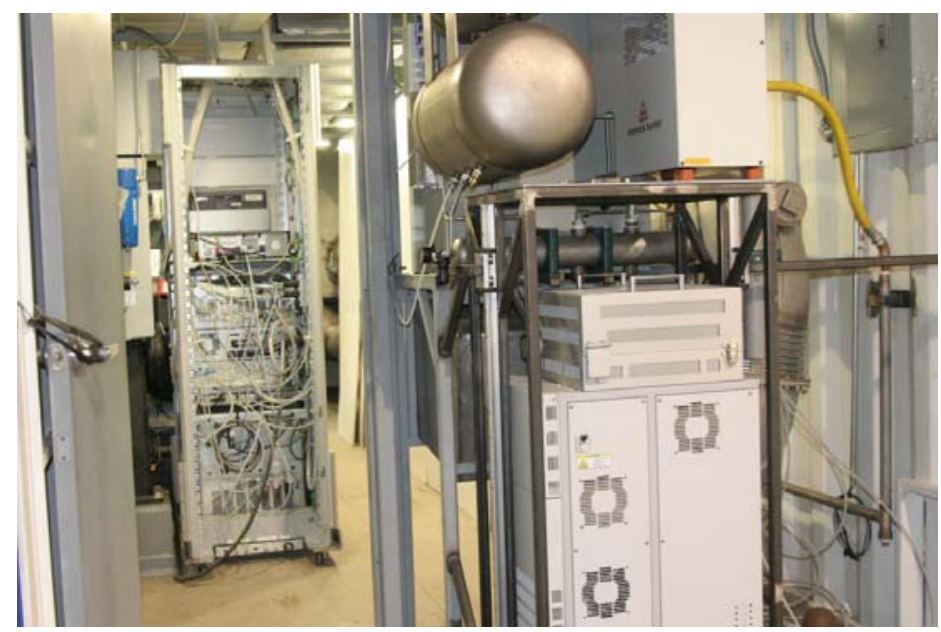

Figure 59: Inside view of the Translab emissions measurement system

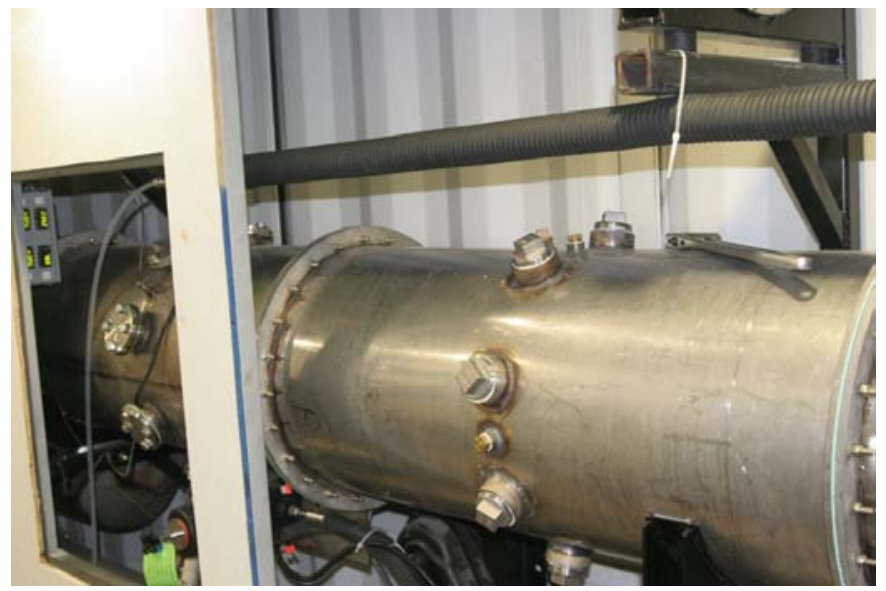

Figure 60: View of the diesel tunnel sample zone 


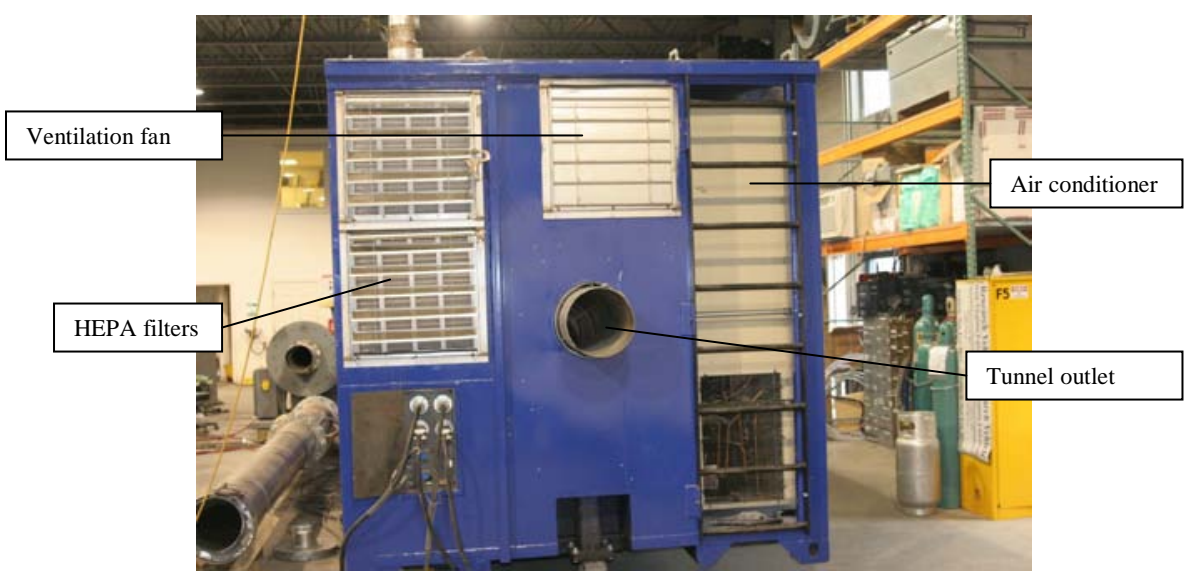

Figure 61: Rear view of the Translab emissions measurement system

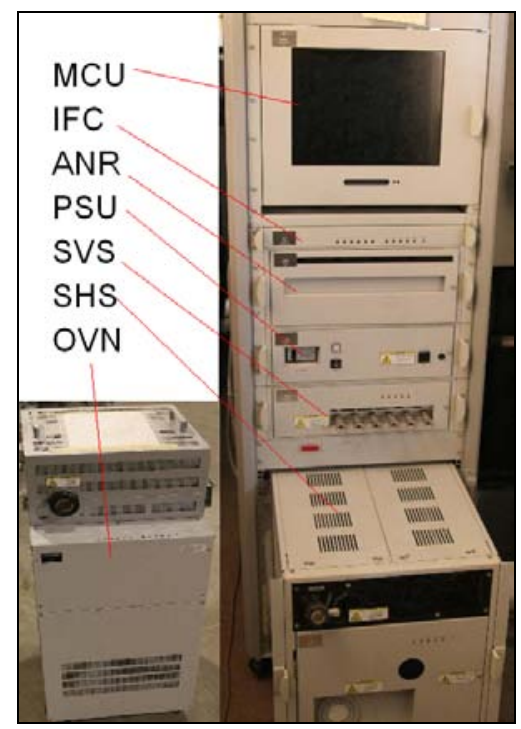

Figure 62: Horiba MEXA 7200D

The completed configuration of the MEXA 7200D was equipped to measure emissions including $\mathrm{HC}, \mathrm{CO} / \mathrm{CO}_{2}$, and $\mathrm{NOx}$. It was composed of eight basic units: the gas divider, the main control unit (MCU), the interface unit (IFC), the analyzer rack (ANR), the power supply unit (PSU), the solenoid valve unit (SVS), the sample handling unit (SHS) and the OVN-700 module. The MCU was based on a personal computer (PC) architecture running the Linux RedHat as operational system. The software of the Horiba 
MEXA 7200D on the MCU controlled and monitored all other modules of MEXA 7200D and could be operated locally as well as be controlled remotely over a laboratory host PC. The IFC was a networking device providing communication between all other modules of MEXA-7200D. The ANR could be fitted with a maximum of 5 analyzer modules. The analyzer modules could be installed to and removed from the ANR without using any tools. One AIA-721A CO analyzer and one AIA-722 $\mathrm{CO} / \mathrm{CO}_{2}$ analyzer were installed in the ANR. The AIA-721A CO analyzer was capable of measuring CO emissions over two setting ranges: $50-2,500 \mathrm{ppm}$ and $100-5,000 \mathrm{ppm}$. The AIA-722 $\mathrm{CO} / \mathrm{CO}_{2}$ analyzer was capable of measuring CO levels over 0.5-12 volume percent (volume \%) and $\mathrm{CO}_{2}$ levels over 3-20 volume \%. The SVS controlled the operational and calibration gases to the analyzer modules. The SHS filters conditioned and pumped the exhaust sample gas to the analyzer modules. The SHS unit was located on a stand alone cart and moved into the bottom section of MEXA 7200D rack. The OVN-700 module combined a FIA-725A THC analyzer and a CLA-720MA NOx analyzer as a joint solution for analyzers operated under sample-heated conditions. The FIA-725A THC analyzer measured HC emission over 10-50,000 ppm and the CLA-720MA NOx analyzer measured NOx emission over 10-10,000 ppm.

A preliminary set of runs was performed to verify the function of major low emissions Translab components, prior to the end date of this contract.

\section{LIST OF TEST SITES}

The following table shows the U.S. DOE funded test sites including their location, fuel types and total number of tests performed.

Table 5: List of test sites with total number of tests

\begin{tabular}{l|l|l|l|}
\hline \multicolumn{1}{|c|}{ Facility } & \multicolumn{1}{|c|}{ City } & State & \multicolumn{1}{c|}{ Fuel } \\
\hline \hline Houston Metropolitan Transit Authority & Houston & TX & Compressed Natural Gas \\
\hline Houston Metropolitan Transit Authority & Houston & TX & Liquified Natural Gas \\
\hline \hline Phoenix Transit System & Phoenix & AZ & Compressed Natural Gas \\
\hline Phoenix Transit System & Phoenix & AZ & Diesel \#1 \\
\hline Phoenix Transit System & Phoenix & AZ & Diesel \#2 \\
\hline Phoenix Transit System & Phoenix & AZ & Methanol-100 \\
\hline New York City Command Bus Company & Brooklyn & NY & Compressed Natural Gas \\
\hline New York City Command Bus Company & Brooklyn & NY & Diesel \#1 \\
\hline \hline New York City Command Bus Company & Brooklyn & NY & Diesel \#2 \\
\hline \hline New York City Command Bus Company & Brooklyn & NY & Methanol-100 \\
\hline Greater Peoria Mass Transit District Agency & Peoria & IL & Diesel \#1 \\
\hline \hline Greater Peoria Mass Transit District Agency & Peoria & IL & Ethanol-93 \\
\hline Greater Peoria Mass Transit District Agency & Peoria & IL & Ethanol-95 \\
\hline \hline Miami Valley Regional Transit Agency & Dayton & OH & Diesel \#1 \\
\hline Pierce County Public Transportation & Tacoma & WA & Compressed Natural Gas \\
\hline
\end{tabular}




\begin{tabular}{|c|c|c|c|}
\hline Facility & City & State & Fuel \\
\hline Pierce County Public Transportation & Tacoma & WA & Diesel \#2 \\
\hline Orange County Transportation Authority & Orange & CA & Compressed Natural Gas \\
\hline Orange County Transportation Authority & Orange & CA & Diesel \#2 \\
\hline Orange County Transportation Authority & Orange & CA & Liquefied Petroleum Gas \\
\hline Orange County Transportation Authority & Orange & CA & Methanol-100 \\
\hline Metro Dade Transit Agency & Miami & FL & Compressed Natural Gas \\
\hline Metro Dade Transit Agency & Miami & FL & Diesel \#1 \\
\hline Metro Dade Transit Agency & Miami & FL & Diesel \#2 \\
\hline Metro Dade Transit Agency & Miami & FL & Methanol-100 \\
\hline Denver Regional Transit District & Denver & $\mathrm{CO}$ & Compressed Natural Gas \\
\hline Denver Regional Transit District & Denver & $\mathrm{CO}$ & Diesel \#2 \\
\hline Denver Regional Transit District & Denver & $\mathrm{CO}$ & Methanol-100 \\
\hline Kanawha Valley Regional Transportation Authority & Charleston & WV & Compressed Natural Gas \\
\hline Kanawha Valley Regional Transportation Authority & Charleston & WV & Diesel \#1 \\
\hline Kanawha Valley Regional Transportation Authority & Charleston & WV & Methanol-100 \\
\hline Metro Council Transit Operations & St. Paul & MN & Diesel \#1 \\
\hline Metro Council Transit Operations & St. Paul & MN & Diesel \#2 \\
\hline Metro Council Transit Operations & St. Paul & MN & Ethanol \\
\hline Metro Council Transit Operations & St. Paul & MN & Ethanol-95 \\
\hline BI-State Development Agency & St. Louis & MO & Bio-diesel \\
\hline BI-State Development Agency & St. Louis & MO & Biodiesel-20 \\
\hline BI-State Development Agency & St. Louis & MO & Diesel \#2 \\
\hline West Virginia University & Morgantown & WV & ARCO EC Diesel 1 \\
\hline West Virginia University & Morgantown & WV & Diesel \#2 \\
\hline West Virginia University & Morgantown & WV & Liquified Natural Gas \\
\hline West Virginia University & Morgantown & WV & Moss Gas 50\%, D2 50\% \\
\hline West Virginia University & Morgantown & WV & Moss Gas Fuel \\
\hline West Virginia University & Morgantown & WV & Ultra low Sulfur Diesel \#1 \\
\hline Tri-County Metropolitan Transit District of Oregon & Portland & OR & Diesel \#2 \\
\hline Tri-County Metropolitan Transit District of Oregon & Portland & OR & Liquified Natural Gas \\
\hline Idaho National Engineering Laboratory & Idaho Falls & ID & Diesel \#2 \\
\hline Idaho National Engineering Laboratory & Idaho Falls & ID & Liquified Natural Gas \\
\hline Flint Mass Transit Authority & Flint & MI & Diesel \#2 \\
\hline Raley's Distribution Center & Sacramento & CA & Diesel \#2 \\
\hline Raley's Distribution Center & Sacramento & CA & Liquified Natural Gas \\
\hline Desert Sands Unified School District & LaQuinta & CA & Compressed Natural Gas \\
\hline Metropolitan Suburban Bus Authority & Garden City & NY & Compressed Natural Gas \\
\hline Southwest Ohio Regional Transit Authority & Cincinnati & $\mathrm{OH}$ & Diesel \#2 \\
\hline Dallas Area Rapid Transit & Dallas & $\mathrm{TX}$ & Diesel \#2 \\
\hline Dallas Area Rapid Transit & Dallas & $\mathrm{TX}$ & Liquified Natural Gas \\
\hline Ralph's Grocery & Riverside & CA & ARCO EC Diesel 1 \\
\hline Ralph's Grocery & Riverside & CA & CA Diesel \\
\hline Ralph's Grocery & Riverside & CA & Compressed Natural Gas \\
\hline
\end{tabular}




\begin{tabular}{|l|l|l|l|}
\hline \multicolumn{1}{|c|}{ Facility } & \multicolumn{1}{|c|}{ City } & State & \multicolumn{1}{c|}{ Fuel } \\
\hline \hline Ralph's Grocery & Riverside & CA & Diesel \#2 \\
\hline Ralph's Grocery & Riverside & CA & Fischer-Tropsch \\
\hline Ralph's Grocery & Riverside & CA & Hydrogen and Methane \\
\hline Ralph's Grocery & Riverside & CA & Liquified Natural Gas \\
\hline Ralph's Grocery & Riverside & CA & Ultra low Sulfur Diesel \#1 \\
\hline Washington Metropolitan Area Transit Authority & Landover & MD & Compressed Natural Gas \\
\hline \hline Washington Metropolitan Area Transit Authority & Landover & MD & Ultra low Sulfur Diesel \#1 \\
\hline \hline
\end{tabular}

\section{LIST OF PUBLICATIONS}

Publications including journal articles, papers in edited books and conference papers and presentations generated from the U.S. DOE funded research program are presented below.

\section{JOURNAL ARTICLES AND PAPERS IN EDITED BOOKS}

BATA, R., CLARK, N.N., LYONS, D.W., PALMER, G.M., LONG, T.R., HOWELL, A., LOTH, J., RAPP, B.L. and WANG, W., "The First Transportable Heavy Duty Vehicle Emissions Testing Laboratory,” 1991 SAE Transactions: Journal of Commercial Vehicles, Vol. 100, 1991, pp. 433-440.

WANG, W.G., PALMER, G.M., BATA, R.M., CLARK, N.N., GAUTAM, M. and LYONS, D.W., "Determination of Heavy Duty Vehicle Energy Consumption by a Chassis Dynamometer," SAE Transactions, Journal of Commercial Vehicles, Vol. 101, 1992, pp. 687-696.

WANG, W.G., BATA, R.M., LYONS, D.W., CLARK, N.N., PALMER, G.M., GAUTAM, M., HOWELL, A.D. and RAPP, B.L., "Transient Response in a Dynamometer Power Absorption System,” SAE Transactions, Journal of Commercial Vehicles, Vol.101, 1992, pp. 42-50

WANG, W., GAUTAM, M., SUN, X., BATA, R., CLARK, N.N., PALMER, G.M., and LYONS, D.W., "Emission Comparisons of Twenty-Six Heavy Duty Vehicles Operated on Conventional and Alternative Fuels,” SAE Transactions, Jour. of Commercial Vehicles, Vol. 102, Section 2, 1994, pp. 31-40.

CLARK, N.N., and McKAIN, D.L., "Transient Chassis Cycles for Heavy Duty Trucks and Tractors,” Int. Jour. of Vehicle Design (Heavy Vehicle Systems), Vol. 2, No. 2, 1995, pp. 143-159.

CLARK, N.N., GAUTAM, M., BATA, R.M., LOTH, J., PALMER, G.M., WANG, W.G., and LYONS, D.W., "Design and Operation of a New Transportable Laboratory for 
Emissions Testing of Heavy Duty Trucks and Buses,” International Jour. of Vehicle Design (Heavy Vehicle Systems), Vol. 2, Nos. 3/4, 1995, pp. 285-299.

WANG, W., LYONS, D.W., BATA, R., CLARK, N.N. and GAUTAM, M., "In-Use Emissions Tests of Alternatively Fueled Heavy-duty Vehicles with a Transportable Chassis Dynamometer,” Proc. Inst. Mech. Engrs., Part D., Journal of Automobile Engineering, England, Vol. 209, 1995.

WANG, W.G., CLARK, N.N., LYONS, D.W., YANG, R.M., GAUTAM, M., BATA, R.M., and LOTH, J.L., "Emissions Comparisons from Alternative Fuel Buses and Diesel Buses with a Chassis Dynamometer Testing Facility,” Environmental Science \& Technology, Vol. 31, 1997, pp. 3132-3137.

CLARK, N.N., GAUTAM,M., LYONS, D.W., BATA, R.M., WANG, W.G., NORTON, P. and CHANDLER, K., "Natural Gas and Diesel Transit Bus Emissions: Review \& Recent Data," SAE Transactions, Journal of Commercial Vehicles, Vol. 106, Section 2, 1998, pp. 487-496.

CLARK, N.N., JARRETT, R.P. and ATKINSON, C.M., "Field Measurements of Particulate Matter Emissions and Exhaust Opacity from Heavy Duty Vehicles,” Journal of the Air \& Waste Management Assoc., Vol. 49, 1999, pp. 76-84.

WAYNE, W.S., CLARK, N.N. and ATKINSON, C.M., “A Parametric Study of Knock Control Strategies for a Bi-Fuel Engine,” 1998 SAE Transactions, Journal of Engines (printed in 1999) Vol. 3, pp. 1387-1393.

RAMAMURTHY, R. and CLARK, N.N., “Atmospheric Emissions Inventory Data for Heavy Duty Vehicles,” Environmental Science \& Technology, Vol. 33, 1999, pp. 55-62.

CLARK, N.N. and LYONS, D.W., "Class 8 Truck Emissions Testing: Effects of Test Cycles and Data on Biodiesel Operation,” Transactions of the American Society of Agricultural Engineers, Vol. 42, No. 5, 1999, pp.1211-1219.

WANG, W.G., LYONS, D.W., CLARK, N.N. and LUO, J.D., "Energy Consumption Analysis of Heavy-duty Vehicles for Transient Emissions Evaluation on Chassis Dynamometer,” Proc. Instn. Mech. Engrs., Jour. of Automobile Eng., Vol. 213, 1999, pp.205-214.

CLARK, N.N., RAPP, B.L., GAUTAM, M., WANG, W.G., and LYONS, D.W., “A Long Term Field Emissions Study of Natural Gas Fueled Refuse Haulers in New York City,” 1998 SAE Transactions , Journal of Fuels \& Lubricants, Vol. 107, pp. 961-972, (printed in 1999) (SAE Paper 982456).

NORTON, P., CLARK, N.N., LYONS, D.W., GAUTAM, M., GOGUEN, S.P., and EBERHARDT, J. "Emissions from Buses with DDC 6V92 Engines using Synthetic Diesel 
Fuel,” 1999 SAE Transactions, Jour. of Fuels \& Lubricants, Vol. 108, pp. 1046-1054 (Printed in 2000)

CLARK, N.N., ATKINSON, C.M., THOMPSON, G.J., and NINE, R.D., “Transient Emissions Comparisons of Alternative Compression Ignition Fuels,” 1999 SAE Transactions, Jour. of Fuels \& Lubricants, Vol. 108, pp. 468-482 (Printed in 2000)

CLARK, N.N., GAUTAM, M., RAPP, B.L., LYONS, D.W., GRABOSKI, M.S., McCORMICK, R.L., ALLEMAN, T.L. and NORTON, P., "Transit Bus Emissions Characterization by Two Chassis Dynamometer Laboratories: Results and Issues,” 1999 SAE Transactions, Jour. of Fuels \& Lubricants, Vol. 108, pp. 801-812 (Printed in 2000) (SAE Paper 1999-01-1469).

WANG, W.G., LYONS, D.W., CLARK, N.N. and GAUTAM, M., "Emissions from Nine Heavy Duty Trucks Fueled by Diesel and Biodiesel without Engine Modification," Environmental Science \& Technology, Vol. 34, 2000, pp. 933-939.

JARRETT, R.P., CLARK, N.N., GILBERT, M. and RAMAMURTHY, R., "Evaluation and Correction of Moisture Adsorption and Desorption From A Tapered Element Oscillating Microbalance,” Powder Technology, Vol. 119, 2001, pp. 215-228.

CLARK, N.N., PRUCZ, J., GAUTAM, M. and LYONS, D.W., “The West Virginia University Heavy Duty Vehicle Emissions Database as a Resource for Inventory and Comparative Studies," SAE Transactions, Journal of Fuels \& Lubricants 2000, (printed in 2001) Vol.109, pp. 2587-2604.

PRUCZ, J.C., CLARK, N.N., GAUTAM, M., and LYONS, D.W., "Exhaust Emissions from Engines of the Detroit Diesel Corporation in Transit Buses: A Decade of Trends," Environmental Science \& Technology, 2001, Vol. 35, 1755-1764.

KERN, J., CLARK, N.N., NINE, R. and ATKINSON, C.M., "Factors Affecting HeavyDuty Diesel Vehicle Emissions,” Jour. of the Air \& Waste Management Assoc., Vol. 52, 2002, pp. 84-94.

GILBERT, M.S. and CLARK, N.N., "Measurement of Particulate Matter from Diesel Engine Exhaust using a Tapered Element Oscillating Microbalance,” International Journal of Engine Research, Vol. 2, No. 4, 2002, pp. 277-287.

CLARK, N.N. and JARRETT, R, "Evaluation of Methods for Determining Continuous Particulate Matter from Transient Testing of Heavy Duty Diesel Engines," SAE Transactions 2001, Journal of Fuels \& Lubricants, Vol. 110, Section 4, pp. 1938-1947 (Printed in 2002) (SAE Paper 2001-01- 3575).

GANESAN, B., and CLARK, N.N., "Relationships between Instantaneous and Measured Emissions in Heavy Duty Applications,” SAE Transactions 2001, Journal of Fuels and 
Lubricants Vol. 110, Section 4, pp. 1798-1806 (Printed in 2002) (SAE Technical Paper 1999-01-1512)

GAJENDRAN, P. and CLARK, N.N., "Effect of Truck Operating Weight on Heavy Duty Diesel Emissions,” Environmental Science \& Technology, Vol. 37 No. 18, 2003, pp. 4309-4317.

LETAVEC, C., UIHLIEN, J., VERTIN, K., CHATTERJEE, S., HALLSTROM, K., WAYNE, W.S., CLARK, N.N., LYONS, D.W., CHANDLER, K. and COBURN, T., "Year-long Evaluation of Trucks and Buses Equipped with Passive Diesel Particle Filters,” 2002 SAE Transactions: Journal of Fuels \& Lubricants Vol. 111 pp. 242-266 (printed in 2003) (SAE Paper 2002-01-0614).

KAMEL, M., LYFORD-PIKE, E., FRAILEY, M., BOLIN, M., CLARK, N.N, NINE, R.D. and WAYNE, W.S., "An Emission and Performance Comparison of the Natural Gas Cummins Westport Inc. C-Gas Plus versus Diesel in Heavy-Duty Trucks," 2002 SAE Transactions: Journal of Fuels \& Lubricants Vol. 111 pp. 1409-1421 (printed in 2003) (SAE Paper 2002-01-2737).

LEV-ON, M., LETAVEC, C, UIHLEIN, J., KIMURA, K., ALLEMAN, T., LAWSON, D., VERTIN, K., THOMPSON, G., CLARK, N.N., GAUTAM, M., WAYNE, W.S., OKAMOTO, R., RIEGER, P., YEE, G., ZIELINSKA, B., SAGEBEIL, J., CHATTERJEE, S., and HALLSTROM, K., "Speciation of Organic Compounds from the Exhaust of Trucks and Buses: Effect of Fuel and After-treatment on Vehicle Profiles," 2002 SAE Transactions, Journal of Fuels \& Lubricants Vol. 111 pp. 1948-1973 (Printed in 2003) (SAE Paper 2002-01-2873).

WAYNE, W.S., CLARK, N.N., NINE, R.D. and ELEFANTE, D., “A Comparison of Emissions and Fuel Economy from Hybrid-Electric and Conventional-Drive Transit Buses,” Energy \& Fuels, Volume 18, No. 1, 2004, pp. 257-270.

TAYLOR, S.T., CLARK, N.N., GAUTAM, M., and WAYNE, W.S. “Diesel Emissions Prediction from Dissimilar Cycle Scaling,” Journal of Automobile Engineering, Volume 218, 2004, pp. 341-352.

ALLEMAN, T.L., BARNITT, R., EUDY, L., MIYASATO, M., OSHINUGA, A., COROCAN, T., CHATTERJEE, S., JACOBS, T., CHERILLO, R.A., CLARK, N.N., and WAYNE, W.S., "Final Operability and Chassis Emissions Results From a Fleet of Class 6 Trucks Operating on Gas-To-Liquid Fuel and Catalyzed Diesel Particle Filters,” Transactions of the SAE, Journal of Fuels \& Lubricants, 2005 (printed in 2006) pp. 14501464. 
GAUTAM, M., CLARK, N.N., LYONS, D.W., LONG, T.R., Jr., HOWELL, A.D., LOTH, J.L., PALMER, G.M. and BATA, R., "Design Overview of A Heavy Duty Mobile Vehicle Emissions Testing Laboratory,” ASME Winter Annual Meeting, Atlanta, 1991, Vol. 40, Advanced Automotive Technology, DE-Vol. 40, ASME, 1991.

LOTH, J.L., LYONS, D.W., HOWELL, A.D., CLARK, N.N., and LONG, T.R., Jr., "Flywheel Design for the WVU Mobile Heavy Duty Truck Testing Facility," ASME Winter Annual Meeting, Atlanta, 1991.

BATA, R., CLARK, N.N., LYONS, D.W., PALMER, G.M., LONG, T.R., HOWELL, A., LOTH, J.L., RAPP, B.L. and WANG, W., "The First Transportable Heavy Duty Vehicle Emissions Testing Laboratory,” International Truck \& Bus Meeting, Chicago 1991, SAE Paper 912668.

WANG, W.G., BATA, R.M, LYONS, D.W., CLARK, N.N., PALMER, G.M. GAUTAM, M., HOWELL, A.D. and RAPP, B.L., "Transient Response in a Dynamometer Power Absorption System,” SAE Paper 920252.

GAUTAM, M., FERGUSON, D., WANG, W.G., BATA, R.M., LYONS, D.W., CLARK, N.N., PALMER, G.M., and KATRAGADDA, S., "In-Use Emission and Performance Monitoring of Heavy Duty Vehicles Using a Transportable Transient Chassis Test Facility,” SAE Int'l. SAE Off-Highway and Power plant Congress, Milwaukee, WI, 1992. SAE Paper 921751.

LYONS, D.W., BATA, R.M., WANG, W.G., CLARK, N.N., PALMER, G.M., HOWELL, A.D., LOTH, J.L., and LONG, T., JR, "Design and Construction of a Transportable Heavy Duty Vehicle Emission Testing Laboratory,” 25th Int. Symp. on Automotive Technology and Automation, Florence, Italy, 1992. Also, Annual Automotive Technology Development Contractors' Coordination Meeting, Dearborn, MI, Oct. 1991, SAE Special Pub., P-256, pp. 593-598.

BATA, R., WANG, W., GAUTAM, M., LYONS, D.W., CLARK, N.N., PALMER, G.M., FERGUSON, D., and KATRAGADDA, S., "Fleet-Site Measurements of Exhaust Gas Emissions from Urban Buses,” Proceedings of ASME Fourteenth Fall Technical Conf., Waterloo, IA, Oct. 1992, Also in New Developments in Off-Highway Engines, ICE-Vol. 18 ASME Special Pub., 1992, pp. 185-196.

GAUTAM, M., FERGUSON, D., NUSSEAR, D.L., PALMER, G.M., LOTH, J.L., LYONS, D.W., CLARK, N.N., BATA, R.M., SANTORO, C. and CHASEY, T., "Emissions Measurement System for a Transportable Heavy Duty Engine Transient Chassis 
Test Facility,” 25th Int. Symp. on Automotive Technology and Automation, Florence, Italy, 1992.

BATA, R., CLARK, N.N., LYONS, D.W., LONG, T.R. Jr., HOWELL, A., LOTH, J., PALMER, G.M., RAPP, B.L. and WANG, W-G., "A Transportable Heavy Duty Vehicle Emissions Testing Laboratory: A New Dimension in Vehicle Testing,” ASME Energy Sources Technology Conf. Houston, TX, 1992, Paper ASME 92-ICE-21.

WANG, W-G., PALMER, G.M., BATA, R.M., CLARK, N.N., GAUTAM, M., and LYONS, D.W., "Determination of Heavy Duty Vehicle Energy Consumption by a Chassis Dynamometer," SAE International Truck and Bus Meeting and Exposition, Toledo, Ohio,1992. SAE Paper 922435.

LYONS, D.W., ATKINSON, C.M., BATA, R.M., CELIK, I., CLARK, N.N., GAUTAM, M., JOHNSON, E.K., MEANS, K.H., PALMER, G.M., and WANG, W., "In-Use Emissions Profiles of Heavy Duty Alternative Fueled Engines,” Oct./Nov. 1992, Annual Automotive Technology Development Contractors' Coordination Meeting, Dearborn, MI, SAE Special Publication, P-265, pp. 181-190.

FERGUSON, D.H., GAUTAM, M., WANG, W.G., CLARK, N.N., LYONS, D.W., BATA, R.M., PALMER, G.M. and KATRAGADDA, S., "Exhaust Emissions from In-Use Heavy Duty Vehicles Tested on a Transportable Transient Chassis Dynamometer,” SAE Int. Truck \& Bus Meeting, Toledo, OH, 1992. SAE Paper 922436.

FERGUSON, D., GAUTAM, M., WANG, W., CLARK, N.N., RAPP, B.L., BATA, R., PALMER, G.M. and LYONS, D.W., "Emissions Data from Alternative and Conventional Fueled Trucks and Buses under Chassis Dynamometer Test Conditions,” ASME Internal Combustion Engine Division Conf., Morgantown, WV, Sept. 1993 (oral only).

WANG, W.G., SUN, X., BATA, R., GAUTAM, M., CLARK, N.N., PALMER, G.M. and LYONS, D.W., "A Study of Emissions from CNG and Diesel-Fueled Heavy Duty Vehicles,” SAE Fuels and Lubricants Meeting, Philadelphia, 1993, SAE Paper 932826. Also published in Gaseous Fuel Technology for the Nineties, SAE Special Pub. P-993, pp. 99-108.

ATKINSON, C.M., LYONS, D.W., CLARK, N.N., PALMER, G.M., GAUTAM, M., WANG, W.G., BATA, R., and McKAIN, D.L., "In-Use Emission Profiles of Diesel and Alternative Fueled Heavy Duty Vehicles,” CRC Third On-Road Vehicle Emissions Workshop, 1993.

WANG, W., GAUTAM, M., SUN, X., BATA, R., CLARK, N., PALMER, M., LYONS, D., "Emission Comparisons of Twenty-Six Heavy-Duty Vehicles Operated on Conventional and Alternative Fuels," SAE Technical Paper 932952, Truck Alternative Fuels and Exhaust Gas Emissions, SAE Special Publication P-1001 1993, pp. 31-40, SAE International Truck \& Bus Meeting and Exposition, Detroit, MI, November 1993. 
KATRAGADDA, S., BATA, R., WANG, W., GAUTAM., M., CLARK, N., LYONS, D., PALMER, M., STANLEY, S., DUNLAP, L., PELLEGRIN, V., WILSON, R., and PORTER, H., "A Correlation Study Between Two Heavy-Duty Vehicle Chassis Dynamometer Emissions Testing Facilities,” SAE Technical Paper 931788, SAE Special Publication Alternative Fuels: Alcohol, Hydrogen, Natural Gas and Propane, also published in Publication, P-982, SAE, August 1993, pp. 81-89. SAE Future Transportation Technology Conference, San Antonio, TX, August 9-12, 1993.

LYONS, D.W., ATKINSON, C.M., BATA, R.M., CELIK, I., CLARK, N.N., GAUTAM, M., JOHNSON, E.K., LOTH, J.L., MEANS, K.H., PALMER, G.M. and WANG, W.G., "Vehicle and Emissions Testing, Characterization and Control," Proceedings of the Annual Automotive Technology Development Contractors' Coordination Meeting, 1993, SAE Publication P-278, pp. 231-238.

TENNANT, C.J., DEJONG, R.D., ATKINSON, R.J., TRAVER, M.L., ATKINSON, C.M., VINCENT, C.J., CLARK, N.N., and LYONS, D. W., "Performance of a high speed engine with dual fuel capability,” SAE Congress, Detroit, Feb., 1994, SAE Paper 940517, also appears in SAE Special Pub. SP -1038.

LYONS, D.W., CLARK, N.N., ATKINSON, C.M., BATA, R.M., WANG, W.G., GAUTAM, M. and PALMER, G.M., "Heavy Duty Vehicle Emissions: Research in Speciation and Results from the WVU Transportable Laboratory,” CRC Fourth On-Road Vehicle Emissions Workshop, San Diego, March, 1994.

CLARK, N.N., McKAIN, D.L., MESSER, T. and LYONS, D.W., "Chassis Test Cycles for Assessing Emissions from Heavy Duty Trucks,” SAE Fuels \& Lubricants Conf., Baltimore, Oct. 1994, SAE Paper 941946, also appears in SAE Special Pub. SP-1053.

TENNANT, C.J., ATKINSON, R.J., TRAVER, M.L., ATKINSON, C.M., and CLARK, N.N., "Turbo charging a Dual Fuel Engine for Gasoline-Equivalent Performance with CNG,” SAE Fuels and Lubricants Conf., Baltimore, Oct. 1994, SAE Paper 942003, also appears in SAE Special Pub. SP-1052.

ATKINSON, R.J., TENNANT, C.J., TRAVER, M.L., ATKINSON, C.M. and CLARK, N.N., "Control and Efficiencies of a Spark Ignition Engine with Dual Fuel Capacity," SAE Fuels and Lubricants Conf., Baltimore, Oct. 1994, SAE Paper 942004, also appears in SAE Special Pub. SP-1052.

WANG, W-G., LYONS, D.L., BATA, R.M., GAUTAM, M., and CLARK, N.N., "In Use Emissions Tests of Alternatively Fueled Heavy Duty Vehicles by a Chassis Dynamometer Testing Facility,” FISITA Paper 945124 (Federation Internationale des Societes d’Ingenieurs des Techniques de l'Automobile). Congress in Beijing, China, Oct. 1994.

CLARK, N.N., ATKINSON, C.M., LYONS, D.W., MOTT, G. and DeJONG, R., "Development of a Closed Loop Fuel Management System for the Hercules 3.7 Liter Lean- 
Burn Natural Gas Engine,” Automotive Technology Development Contractors Coordination Meeting, Dearborn, Michigan, 1994.

GAUTAM, M., KELLY, B., GUPTA, D., CLARK, N.N., ATKINSON R., EL-GAZZAR, L. and LYONS, D.W., "Sampling Strategies for Characterization of the Reactive Components of Heavy Duty Diesel Exhaust Emissions,” SAE Truck \& Bus Meeting, Seattle, Washington, Nov. 1994.

ATKINSON, C. M., TRAVER, M.L, TENNANT, C.J., ATKINSON, R.J., and CLARK, N.N., "Exhaust Emissions and Combustion Stability in a Bi-Fuel Spark Ignition Engine," SAE Congress, Detroit, 1995, SAE Paper 950468.

ATKINSON, C.M., CLARK, N.N., McKAIN, D.L., EL-GAZZAR, L., and LYONS, D.L., "Speciation of Heavy-Duty Engine Exhaust Emissions," 5th. CRC On-Road Emissions Workshop, San Diego, CA, April 1995.

CLARK, N.N., LYONS, D.W., WANG, W.G., BATA, R.M., GAUTAM, M., KELLY, K. and WHITE, C.L., "Emissions from Alcohol, Natural Gas \& Biodiesel Buses,” 5th CRC On-Road Emissions Workshop, San Diego, CA, April 1995.

McKAIN, D.L., ATKINSON, C.M., El-GAZZAR, L., LYONS, D.W., AND CLARK, N.N., "Speciation of Exhaust from Low Emissions Diesel Engines," SAE Congress, Detroit, 1995, Oral Presentation.

MESSER, J.T. and CLARK, N.N., "Measurement Delays and Modal Analysis for a Transportable Heavy Duty Vehicle Emissions Testing Laboratory,” SAE Congress, Detroit 1995, SAE Paper 950218.

CLARK, N.N., MESSER, J.T., WANG, W., BATA, R.M. and LYONS, D.W., "Use of the West Virginia University Truck Test Cycle to Evaluate Emissions from Class 8 Trucks," SAE Congress, Detroit 1995, SAE Paper 951016.

TENNANT, C.J., ATKINSON, R.J., TRAVER, M.L., WAYNE, W.S., ATKINSON, C.M., and CLARK, N.N., "Design of a Bi-Fuel engine which Avoids the Penalties Associated with Natural Gas Operation,” SAE Congress, Detroit 1995, SAE Paper No. 950679.

CLARK, N.N., GADAPATI, C.J., WANG, W.G., BATA, R.M., GAUTAM, M., and LYONS, D.W., “Comparative Emissions from Natural Gas and Diesel Buses,” SAE Alternative Fuels Conf., San Diego, Dec. 1995, SAE Paper 952746.

MOTT, G.E., ATKINSON, C.M., CLARK, N.N., ATKINSON, R.J., DeJONG, R.J., LATVAKOSKI, T.E., and TRAVER, M.L., "Effect of Fuel Composition on the Operation of a Lean Burn Natural Gas Engine,” SAE Fuels \& Lubricants Meeting, Toronto, Oct. 1995 and SAE Alternative Fuels Conf., San Diego, Dec. 1995, SAE Paper 952560. 
TENNANT, C.J., ATKINSON, R.J., TRAVER, M.L., ATKINSON, C.M. and CLARK, N.N., “A Bi-fuel Engine for the Transition to CNG Usage,” ASME Internal Combustion Engine Division, 1995 Fall Technical Conference.

MOTT, G.E., ATKINSON, C.M., CLARK, N.N. and ATKINSON, R.J., “Closed Loop Engine Control for Turbocharged Lean Burn Natural Gas Engine Operation,” ASME Internal Combustion Engine Division, 1995 Fall Technical Conference.

GERTLER, A.W., SAGEBEIL, J.C., PIERSON, W.R., ATKINSON, C.M. and CLARK, N.N., "On-Road Chassis Dynamometer and Engine-Out Dynamometer Measurements of Heavy-Duty Vehicle Emission Factors,” Proceedings of the A\&WMA Conference on the Emission Inventory: Programs \& Progress, RTP, NC 11-13 October 1995. Air \& Waste Management Association, Pittsburgh, PA. (Proceedings published in 1996).

BATA, R.M., LYONS, D.W., CLARK, N.N., GAUTAM, M., WANG, W-G., BROWN, D. and HEYDORN, E., "Vehicle Performance and Exhaust Gas Emissions of In-use Methanol Fueled Transit Buses,” Eleventh International Symposium on Alcohol Fuels, S. Africa, April 1996.

CLARK, N.N., WANG, W.G., BATA, R.M., GAUTAM, M., LYONS, D.W., KELLY, K. and WHITE, C., "Emissions from Heavy Duty Trucks and Buses Operating on Ethanol Based Fuels,” Eleventh International Symposium on Alcohol Fuels, S. Africa, April 1996.

NINE, R.D., ATKINSON, C.M., McKAIN, D.L., EL-GAZZAR, L., CLARK, N.N. and LYONS, D.W., "Speciation of Diesel Exhaust from a Medium Duty Diesel Engine,” SAE Congress, Detroit, MI, Feb. 1996, SAE Paper 960322, Also in Special Publication SP-1159.

ATKINSON, C.M., CLARK, N.N. and LYONS, D.W., "An Estimation of the Comparative Contribution of Heavy-Duty Diesel Buses and Trucks to Mobile Source Emissions,” 6th CRC On-Road Emissions Conf., San Diego, March 1996.

CLARK, N.N. and LYONS, D.W., "Driving Routes (or Icon Tests) for Heavy Duty Truck Emissions Measurement,” 6th CRC On-Road Emissions Conf., San Diego, CA, March 1996.

GAUTAM, M., BYRD, R., LYONS, D.W., WANG, W.G., CLARK, N.N. and BATA, R., "Correlation of Total Particulate Matter and Smoke Emissions from in-use Heavy Duty Vehicles,” 6th CRC on-Road Emissions Conf., San Diego, CA, March 1996.

NINE, R.D., CLARK, N.N., ATKINSON, C.M., MOTT, G.E., and MACE, B.E., "Speciation of Reactive Components of Lean Burn CNG Exhaust Emissions," Poster Presentation, Windsor Workshop on alternative Fuels, Toronto, June 1996.

CLARK, N.N., ATKINSON, C.M., LYONS, D.W., MOTT, G.E., ATKINSON, R.J., De JONG, R.J., and LATVAKOSKI, T.E., "Closed Loop Fueling Control For A Lean Burn 
Natural Gas Engine,” Poster Presentation, Windsor Workshop on Alternative Fuels, Toronto, June 1996.

CLARK, N.N., WANG, W.G., LYONS, D.W., GAUTAM, M. and BATA, R.M., “Troubleshooting High Emissions from In-Service Alternative Fueled Buses,” Windsor Workshop on Alternative Fuels (Proceedings), pp. 421-437, Toronto, June 1996.

CLARK, N.N., and LYONS, D.W., "Comparative Emissions from Chassis Tests Of Trucks Using Diesel No.2 and Biodiesel Blend,” Poster Presentation, Windsor Workshop on Alternative Fuels (Proceedings), Toronto, June 1996.

CLARK, N.N. and LYONS, D.W., "Emissions from CNG and Diesel Refuse Haulers Using Six Engine Types in New York City,” Seventh CRC On-Road Vehicle Emissions Workshop, San Diego, April 1997, pp. 5-49 to 5-64.

HARRIS, D.B., KING., F., BROWN, J.E., NINE, R.D., CLARK, N.N. and KOPASKO, J., "Comparison of On-Road and Chassis Dynamometer Emissions Results," Seventh CRC On-Road Vehicle Emissions Workshop, San Diego, April 1997, pp. 5-93 to 5-111.

CLARK, N.N., LYONS, D.W., GAUTAM, M., BATA, R.M., and WANG, W.G., "Field Emissions Testing of Heavy Duty Natural Gas Vehicles”, Windsor Workshop on Transportation Fuels, Windsor, Ontario, 1997.

NINE, R.D., CLARK, N.N., MACE, B.E. and EL-GAZZAR, L., "Hydrocarbon Speciation of a Lean Burn Spark Ignited Engine,” SAE Fuels \& Lubricants Conf., Tulsa, OK, October 1997, SAE Paper 972971.

CLARK, N.N., LYONS, D.W., BATA, R.M., GAUTAM, M., WANG, W.G., NORTON, P., and CHANDLER, K., "Natural Gas and Diesel Transit Bus Emissions: Review and Recent Data,” SAE Truck and Bus Conference, Cleveland, OH, Nov. 1997, SAE Paper 973203.

CLARK, N.N., LYONS., D.W., WANG, W.G., GAUTAM, M. and ATKINSON, C.M., "Emissions from Buses using New Generation Natural Gas Engines," Annual Automotive Technology Customers’ Coordination Meeting, Dearborn, MI, Oct. 1998, Poster and Proceedings, Vol. III, pp. 491-497.

GAUTAM, M., LYONS, D.W., CLARK, N.N., WANG, W.G. and BERGIN, M., "In-use Particulate Matter Emissions from Heavy Vehicles,” Annual Automotive Technology Customers' Coordination Meeting, Dearborn, MI, Oct. 1997, Poster and Proceedings, Vol. III, pp. 559-562.

WAYNE, W.S., CLARK, N.N. and ATKINSON, C.M., “A Parametric Study of Knock Control Strategies for a Bi-Fuel Engine,” SAE International Congress, Detroit, Feb. 1998, SAE Paper 980895. 
CHANDLER, K., NORTON, P. and CLARK, N.N., “Alternative Fuel Truck Evaluation Project - Design and Preliminary Results,” SAE Spring Fuels and Lubricants Meeting, Dearborn, MI, May 1998, SAE Paper 981392.

CLARK, N.N., LYONS, D.W., RAPP, B.L, GAUTAM, M., WANG, W.G., NORTON, P., WHITE, C. and CHANDLER, C., "Emissions from Trucks and Buses Powered by Cummins L-10 Natural Gas Engines,” SAE Spring Fuels and Lubricants Meeting, Dearborn, MI, May 1998, SAE Paper 981393.

BHARGAVA, S., HILDEBRAND, M.W. and CLARK, N.N., "Exhaust Gas Recirculation in a Lean Burn Natural Gas Engine,” SAE Spring Fuels and Lubricants Meeting, Dearborn, MI, May 1998, SAE Paper 981395.

CLARK, N.N., JARRETT, R.P. and ATKINSON, C.M., "Field Measurements of Particulate Matter Emissions and Exhaust Opacity from Heavy Duty Vehicles,” Air \& Waste Management Assoc. / EPA International Specialty Conf., Long Beach, CA 1998.

CLARK, N.N, ATKINSON, C.M., LYONS, D.W., and RAMAMURTHY, R., "Models for Predicting Transient Heavy Duty Vehicle Emissions,” SAE Fall Fuels \& Lubricants Meeting, San Francisco, October, 1998, SAE Paper 982652.

NORTON, P., VERTIN, K.D., BAILEY, B.K., CLARK, N.N., LYONS, D.W., EBERHARDT, J. and GOGUEN, S.J., "Emissions from Trucks using Fischer-Tropsch Diesel Fuel,” SAE Fall Fuels \& Lubricants Meeting, San Francisco, October, 1998, SAE Paper 982526.

WAYNE, W.S., CLARK, N.N. and ATKINSON, C.M., "Numerical Prediction of Knock in a Bi-Fuel Engine,” SAE Fall Fuels \& Lubricants Meeting, San Francisco, October, 1998, SAE Paper 982533.

CLARK, N.N. and LYONS, D.W., "Class 8 Truck Emissions Testing: Effects of Test Cycles and Data on Biodiesel Operation,” American Society of Agricultural Engineers Meeting, Orlando, Fl., July 1998. ASAE Paper 986082

CLARK, N.N., GAUTAM, M., BOYCE, J.A., WANG, W.G., and LYONS, D.W., "Emissions Performance of Natural Gas and Diesel Fueled School Buses with Cummins 8.3 liter Engines,” ASME Internal Combustion Engine Division Spring Conf., Columbus, In., 1999. ASME Paper No. 99-ICE-176. Appears in Proceedings, Vol. 2, "Experimental Studies in Engines and Natural Gas and Alternative Fuels”, pp. 17-24.

McKAIN, D.L. and CLARK, N.N., "Speed, Torque and Power Regressions for Quality Control of Heavy Duty Vehicle Chassis Dynamometer Research,” SAE Congress, Detroit, March 1999, SAE Paper 1999-01-0614.

KELLY, T., SPUCKLER, D., SVERDRUP, G., CALLAHAN, P., CLARK, N.N., KERN, J.M., ATKINSON, C.M., NINE, R.D., MULLEN, M. and WILSON, J., "Review of Air 
Quality Impacts from Diesel and Gasoline Powered Vehicles,” $9^{\text {th }}$ CRC On-Road Vehicle Emissions Workshop, San Diego, April, 1999.

ATKINSON, C.M., CLARK, N.N., and LYONS, D.W., "Emissions Reduction Benefits of Fischer-Tropsch and Other Alternative Liquid Fuels in Heavy Duty Diesel Engines," $9^{\text {th }}$ CRC On-Road Vehicle Emissions Workshop, San Diego, April, 1999.

GAUTAM, M., MEHTA, S., BUGARSKI, A., BYERS, R., CLARK, N.N., and LYONS, D.W., "Particle Size Distributions from In-use Heavy-Duty Diesel Vehicles," $9^{\text {th }}$ CRC OnRoad Vehicle Emissions Workshop, San Diego, April, 1999.

CHANDLER, K.L., NORTON, P. and CLARK, N.N., "Update from the NREL Alternative Fuel Transit Bus Evaluation Program,” American Public Transit Assoc., 1999 Bus Conference, Cleveland, Ohio.

CLARK, N.N., GAUTAM, M., LYONS, D.W., ATKINSON, C.M., XIE, W-W., NORTON, P., VERTIN, K., GOGUEN, S.P. and EBERHARDT, J. "On-Road Use of Fischer-Tropsch Diesel Blends,” 1999 SAE Government/Industry Meeting, Washington, DC, SAE Paper 1999-01-2251

CLARK, N.N., GAUTAM, M. and LYONS, D.W., "Chassis Dynamometer Emissions Comparison of Medium Duty Buses on Natural Gas,” 1999 Windsor Workshop on Transportation Fuels, Toronto, Ont., 1999.

PARK, T., ATKINSON, R.J., CLARK, N.N., TRAVER, M.L. and ATKINSON, C.M., "Operation of a Compression Ignition Engine with a HEUI Injection system on Natural Gas with Diesel Pilot Injection,” 1999 SAE Fall Fuels \& Lubricants Meeting, Toronto, Ont., 1999. SAE Paper 1999-01-3522

NORTON, P., FRAILEY, M.R., ADDY, J.M., CLARK, N.N., LYONS, D.W., GAUTAM, M., and BECK, N.J., "Chassis Dynamometer Emission Measurements of Trucks \& Buses using Dual Fuel Natural Gas Engines,” 1999 SAE Fall Fuels \& Lubricants Meeting, Toronto, Ont., 1999. SAE Paper 1999-01-3525

WAYNE, W.S., CLARK, N.N., GAUTAM, M., and LYONS, D.W., "Research Approach for Aging and Evaluating Diesel Exhaust Catalysts,” 2000 Diesel Engine Emission Reduction Workshop, San Diego CA, August 20-24, 2000.

FRAILEY, M., NORTON, P., CLARK, N.N., and LYONS, D.W., “An Evaluation of Natural Gas versus Diesel in Medium-Duty Buses,” SAE Fuels \& Lubricants Meeting, Baltimore, Oct. 2000, SAE Paper 2000-01-2822.

CLARK, N.N., PRUCZ, J., GAUTAM, M. and LYONS, D.W., "Heavy Duty Vehicle Chassis Dynamometer Emissions Data as a Resource for Inventory \& Comparative Studies," SAE Fuels \& Lubricants Meeting, Baltimore, Oct. 2000, SAE Paper 2000-012854. 
CLARK, N.N., XIE, W-W., GAUTAM, M., LYONS, D.W., NORTON, P., and BALON, T., "Hybrid Diesel-Electric Heavy Duty Bus Emissions: Benefits of Regeneration and Engine Load Smoothing," SAE Fuels \& Lubricants Meeting, Baltimore, Oct. 2000, SAE Paper 2000-01-2955.

CLARK, N.N., GAUTAM, M., BOYCE, J., LYONS, D.W., VERTIN, K., and LETAVEC, C.A., "Class 8 Trucks Operating on Ultra-Low Sulfur Diesel with Catalyzed Particle Filters: Regulated Emissions,” SAE Fuels \& Lubricants Meeting, Baltimore, Oct. 2000, SAE Paper 2000-01-2815.

CLARK, N.N., GAUTAM, M., LYONS, D.L., NINE, R.D., VERTIN, K., NORTON, P., GOGUEN, S. and EBERHARDT, J.J., "Low Emissions Compression Ignition Fuels," Poster Presentation, Windsor Workshop on Transportation Fuels, Toronto, June 2000.

CHATERJEE, S., MCDONALD, C., CONWAY, R., WINDAWI, H., VERTIN, K., LETAVEC, C.A., CLARK, N.N., and GAUTAM, M., "Emissions Reductions and Operational Experiences with Heavy Duty Diesel Fleet Vehicles Retrofitted with Catalytically Regenerated Particulate Filters in Southern California,” 2001 Society of Automotive Engineers Congress, Detroit, MI, SAE Paper 2001-01-0512.

WAYNE, W.S., CORRIGAN, E., CLARK, N.N., GAUTAM, M., EVANS, J., NINE, R., LYONS, D.W., REN, S., WHITACRE, S., CLARK, W., GORSE, R., ORBAN, J., and STOREY, J., "Evaluation of Fuel Sulfur Effects on Diesel Oxidation and Lean NOx Catalysts,” $11^{\text {th }}$. CRC On-Road Emissions Workshop, March 2001, San Diego.

WAYNE, W.S., CLARK, N.N., GAUTAM, M., LYONS, D.W., AND SNYDER, J., "Experimental Determination of Fuel Sulfur Effects on Oxidation and Lean-NOx Diesel Engine Catalysts,” 2001 Diesel Engine Emissions Reduction Workshop, Norfolk, VA, August 2001

CLARK, N.N., GAUTAM, M., LYONS, D.W., VERTIN, K., and LETAVEC, C., "Reduction of Particulate Matter from Truck \& Bus Diesel Engines using ECD Ultra Low Sulfur Fuel and Exhaust Gas Filtration,” $11^{\text {th }}$. CRC On-Road Emissions Workshop, March 2001, San Diego.

WAYNE, W.S., CORRIGAN, E., CLARK, N.N., GAUTAM, M., LYONS, D.L., and EVANS, J., "Measuring Diesel Emissions with a Split Exhaust Configuration,” SAE Spring Fuels \& Lubricants Meeting, Orlando, 2001.

WAYNE, W.S., SNYDER, J.M., PERTL, F.A., ATKINSON, R.J., CLARK, N.N., GAUTAM, M., and LYONS, D.W., "Research Approach for Aging and Evaluating Diesel Lean-NOx Catalysts," SAE Fall Fuels \& Lubricants Meeting, San Antonio, TX, 2001, SAE Paper 2001-01-3620. 
WAYNE, W.S., NINE, R.D., CLARK, N.N., GAUTAM, M., MOYNIHAN, P., BALON, T., CHAIRMONTE, M., and PROSTAKOV, M., "Reduction of PM Emissions from Refuse Trucks through Retrofit of Diesel Particulate Filters,” SAE/JSAE Spring Fuels \& Lubricants Meeting , Yokohama, Japan 2003, 20030285

CLARK, N.N., GAUTAM, M., WAYNE, W.S., LONG, T.R., LYONS, D.W., THOMPSON, G.J., and MALDONADO, H., "Emissions from Medium Heavy-Duty Trucks in Southern California,” 15TH CRC ON-ROAD VEHICLE EMISSIONS WORKSHOP, April 4-6 2005, San Diego, California.

\section{LIST OF STUDENTS SUPPORTED BY DOE FUNDED PROJECTS}

Following is a list of students who have worked in the U.S. DOE funded research programs during their graduate programs at WVU.

Ph.D. (DOCTOR OF PHILOSOPHY) STUDENTS

Bugarski, Aleksandar

Ferguson, Donald

Gajendran, Prakash

Katragadda, Sunil

Kim, Donghee

Krishnamurthy, Mohan

Mckenzie, Eugene

Petreanu, Sorin

Tennant, Christopher J.

Traver, Michael L.

Wayne, W. Scott

Wilt, Glen

Yacoub, Yasser

\section{M.S. (MASTER OF SCIENCE) STUDENTS}

Amandus, Nicholas P.

Ames, Robert

Andrei, Paul

Aravelli, Aparna

Azu, Akunor

Bane, Bradley R.

Barnett, Ryan A.

Bhargava, Sumit

Buffamonte, Thomas 
Byers, Richard J.

Byrd, Randall

Chasey, Timothy D.

Corrigan, Eric

DeJong, Remco

Evans, Jason

Ferguson, Donald

Flaugher, Joshua

Fuller, Andrew D.

George, Sam

Gilbert, Marcus

Govindareddy, Mahesh

Gupta, Deepak

Hall, Timothy

Hashemi, Nastaran

Hoppie, Jennifer A.

Jarrett, Ronald P.

Jayasinghe, Chandima S.

Kelly, Brian

Khan, ABM Siddiqur

Knight, Jared

Krishnamurthy, Mohan

Laeeq, Muhammad

Latvakoski, Timo E.

Looney, Kenneth B.

Luo, Handong

McConnell, Steve

Messer, J. Todd

Meyer, Eric

Miller, Franklin

Nagendran, Vinay

Narasimhamurthy, Praveen

Nayak, Gurudutt A.

Nennelli, Anjali

Nine, Ralph

Nuszkowski, John

Nyika, Paidamoyo A.

Park, Talus

Popuri, Siram S.

Radermacher, J. Axel

Ramamurthy, Ravishankar

Reddy, Varakala

Rosepiler, Stephen G.

Salem, Mohamed

Santoro, Christopher M.

Shade, Benjamin C. 
Sindler, Petr

Smith, Anna Marie

Smith, Jeffrey

Tehranian, Azadeh

Tennant, Christopher

Thiagarajan, Sairam

Toth-Nagy, Csaba

Traver, Michael

Venkatasubramaniam, K. C.

Vora, Kuntal

Wilt, Glen

Xie, Wenwei

$\mathrm{Xu}$, Zhuyun

Yacoub, Yasser

Yang, Ruimin

Yao, Pei

Yocum, Aaron

Zimmerman, Andrew

\section{CONCLUSIONS}

A Transportable Heavy-Duty Vehicle Emissions Testing Laboratory (Translab) was designed, constructed and verified to quantify emissions from alternatively fueled vehicles. This Translab consisted of a chassis dynamometer semi-trailer and an analytic trailer housing a full scale exhaust dilution tunnel and sampling system which mimicked closely the system described in the Code of Federal Regulations for engine certification. The Translab was first used to quantify emissions from natural gas and methanol fueled transit buses, and a second Translab unit was constructed to satisfy research demand. Early natural gas fueled buses showed low particulate matter emissions but highly variable oxides of nitrogen emissions relative to diesel control vehicles. In all cases the levels of carbon monoxide, oxides of nitrogen, hydrocarbons, carbon dioxide and particulate matter were quantified, and in many cases non-regulated species such as aldehydes were also sampled. Emissions measurement was also performed on trucks and buses using ethanol, Fischer-Tropsch fuel, and biodiesel. All three of these fuels demonstrated reductions in particulate matter relative to conventional diesel fuel. A medium-duty chassis dynamometer was designed and constructed to facilitate research on delivery vehicles in the 10,000 to 20,000lb.weight range operating on Fischer-Tropsch fuel. The Translab participated in major programs to evaluate low-sulfur diesel in conjunction with passively regenerating exhaust particulate filtration technology. Data showed substantial reduction in PM, with the filters remaining active due to the low sulfur content of the fuel. Further measurement was undertaken to evaluate emissions from advanced natural gas engines with closed loop feedback control. These engines showed lower and more stable NOx levels than their mechanically-controlled predecessors. Particle size was also quantified during selected studies. Techniques for 
creating heavy-duty vehicle test schedules were developed to satisfy the real-world emissions measurement need, and schedules to mimic a variety of truck and bus vocations were created and employed by the Translab.

The research team also conducted supporting studies to advance the understanding of alternative fuels applications. These studies did not employ the Translab directly, but were implemented on test stands with separate exhaust dilution and analyzers. Studies were aimed at both natural gas and liquid fuel applications. While most of the programs were geared to the use of a single engine, the Diesel Emissions Control - Sulfur Effects (DECSE) activities conducted by WVU involved four engines with extended operation to clarify the effects of fuel sulfur on advanced diesel engine aftertreatment devices. Other studies developed an approach for optimizing bi-fuel engine performance on natural gas, while another developed a dual-fuel diesel/natural gas engine control strategy.

From 2002 onward emissions levels (particularly of PM) of many trucks and buses were reduced such that that they were at or below the Translab detectable limits. More recently the US Environmental Protection Agency required improved measurement methodologies for engine emissions certification. To remain current and relevant, the researchers designed a new Translab analytic system, housed in a container which could be transported on a semi-trailer. The new system's dilution tunnel flow was designed to use a subsonic venturi with closed loop control of blower speed, and the secondary dilution and particulate matter filter capture were designed to follow new EPA engine certification procedures.

\title{
PARTICIPATING FACULTY
}

The following WVU faculty, in alphabetic order, contributed to the program.

\author{
Christopher Atkinson \\ Reda Bata \\ Ismail Celik \\ Nigel Clark \\ Mridul Gautam \\ John Loth \\ Kenneth Means \\ G. Michael Palmer \\ Gregory Thompson \\ Wenguang Wang \\ W. Scott Wayne
}

\section{ACKNOWLEDGEMENTS}

The WVU researchers acknowledge the guidance over the duration of the program of DOE Technology Development Managers, most recently Stephen Goguen and Kevin 
Stork. The researchers also acknowledge the management of the program over its duration by the Chicago Operations Office, the Golden Field Office and the National Energy Technology Laboratory (NETL) and thank Ralph Nine of NETL for his participation.

\section{REFERENCES}

1. Protection of the Environment. Code of Federal Regulations, Part 86, Subpart N, Title 40. U.S. Government Printing Office, Washington D.C. 2005.

2. Clark, N.N., Gautam, M., Bata, R.M., Wang, W.G., Loth, J.L., Palmer, G.M., and Lyons, D.W., "Design and Operation of a New Transportable Laboratory for Emissions Testing of Heavy-Duty Trucks and Buses,” International Journal of Vehicle Design, Heavy Vehicle Systems. Vol. 2, No. 3/4, pp. 308-322, 1995.

3. Lyons, D., Bata, R. M., Wang, W.G., Clark, N.N., Palmer, G.M., Gautam, M., Howell, A., Loth, J., and Long, T. Jr., "Design and Construction of a Transportable Heavy Duty Vehicle Emission Test Laboratory,” ISATA Paper No. 920450, 25th International Symposium on Automotive Technology and Automation (ISATA), Florence, Italy, 1992.

4. Gautam, M., Clark, N., Lyons, D., Long, T. Jr., Howell, A., Loth, J., Palmer, G.M., Wang, W., G., and Bata, R. M., "Design Overview of a Heavy Duty Mobile Vehicle Emissions Testing Laboratory,” ASME DE - Vol. 40, Advanced Automotive Technologies, pp.199-207, 1991.

5. Clark, N.N., Borrell, E.R., McKain, D.L., Paramo, V.H., Wayne, W.S., Vergara, W., Barnett, R. A., Gautam, M., Thompson, G., Lyons, D.W., and Schipper, L., "Evaluation of Emissions from New and In-Use Transit Buses in Mexico City," Paper No. 06-1092, 85 ${ }^{\text {th }}$ Annual Meeting of the Transportation Research Board, 2006.

6. Nylund, N-O., Erkkila, K., "Evaluation of Duty Cycles for Heavy-Duty Urban Vehicles,” Report to the International Energy Agency (IEA), Finland, 2005.

7. Clark, N.N., Tehranian, A., Jarrett, R.P., and Nine, R.D., “Translation of Distance-Specific Emissions Rates between Different Heavy-Duty vehicle Chassis test Schedules,” SAE Paper 2002-01-1754, 2002.

8. Coroller, P., Plassat, G., "Comparative Study on Exhaust Emissions from Diesel and CNG-Powered Urban Buses,” Proceedings of the Diesel Engine Emissions Reduction Conference (DEER), 2003.

9. SAE Standard J2711 Recommended Practice for Measuring Fuel Economy and Emissions of Hybrid-Electric and Conventional Heavy-Duty Vehicle, Society of Automotive Engineers, Document No. J2711, 2002.

10. Wayne, W.S., Clark, N.N., Nine, R.D., and Rosepiler, S., "Washington Metropolitan Area Transit Authority Diesel Emissions Control Retrofit Project," Final Report by the West Virginia University, Morgantown, WV, 2002.

11. Test Cycles, http://www.dieselnet.com/standards/cycles/etc.html, Accessed on Aug10, 2006 
12. Thompson, E.D., Ansari, M., and Eberhard, G.A., "A Truck and Bus Chassis Dynamometer Developed for Fuels and Lubricants Research,” SAE Paper 902112, 1990.

13. Fuel Economy Measurement Test (Engineering Type) for Trucks and Buses, Society of Automotive Engineering Standards, J1376.

14. Nine, R.D., Clark, N.N., Daley, J.J., and Atkinson, C.M., "Development of a Heavy-Duty Chassis Dynamometer Driving Route,” Proceedings of the Institute of Mechanical Engineers, Part D., Journal of Automobile Engineers, Vol. 213, pp. 561-574, 1999.

15. Wayne, W.S., Nine, R., Clark, N.N., and Schiavone, J.J., "Diesel Engine Retrofit Program, Interim Task Report: Emissions Results,” Presented to Westchester County Department of Transportation, October, 2002.

16. Clark, N.N., Gautam, M., Wayne, W.S., Riddle, W., Nine, R.D., Lyons, D.W., and $\mathrm{Xu}, \mathrm{S}$., "Examination of Heavy Heavy-Duty Diesel Truck Chassis Dynamometer Schedule,” SAE Paper 2004-01-2904, 2004.

17. Chandler, K., Walkowicz, K., "Emissions, Fuel Economy, and In-use Performance Evaluation of King County Metro Transit's Hybrid Buses,” Presented at 2006 APTA Bus \& Paratransit Conference, Orange County, CA, 2006.

18. Khan, A.S., Clark, N.N., Thompson, G.J., Wayne, W.S., Gautam, M., Lyons, D.W., and Hawelti, D., "Idle Emissions from Heavy-Duty Diesel Vehicles Review and Recent Data,” Journal of the Air \& Waste Management Association, Vol. 56, pp. 1404-1419, 2006.

19. Clark, N.N., Khan, A.S., Wayne, W.S., Lyons, D.W., Gautam, M., McKain, D.L., Thompson, G.J., Barnett, R., "Weight Effect on Emissions and Fuel Consumption from Diesel and Lean-Burn Natural Gas Transit Buses,” SAE Paper 2007-013626, August 2007.

20. Collings N., K. Reavell, T. Hands., J. Tate, "Roadside Aerosol Measurements with a Fast Particulate Spectrometer,” JSAE Paper 20035407, 2003.

21. Kittelson, D., T. Hands, C. Nickolaus, N. Collings, V. Niemela, and M. Twigg, "Mass Correlation of Engine Emissions with Spectral Instruments," $10^{\text {th }}$ Diesel Engine Emissions Reduction (DEER) Workshop, Coronado, CA, 2004.

22. Reavell, K., T. Hands, and N. Collings, "A Fast Response Particulate Spectrometer for Combustion Aerosols,” SAE Paper 2002-01-2714, 2002.

23. Reavell K.S., T. Hands, and N. Collings, "Determination of Real Time Particulate Size Spectra and Emission Parameters with a Differential Mobility Spectrometer," 6th International ETH-Conference on Nanoparticle Measurement, Zurich, Switzerland, 2002.

24. Eastlake, A., “The Latest Developments in Heavy Duty Vehicle Aftertreatment Testing for Real World Emissions and Fuel Economy,” SAE Paper 1999-01-0470, 1999.

25. Wang, W. Gautam, M., Sun, X., Bata, R., Clark, N., Palmer, G.M., and Lyons, D., "Emissions Comparisons of Twenty-Six Heavy-Duty Vehicles Operated on Conventional and Alternative Fuels,” SAE Paper 932952, 1993. 
26. Clark, N.N., Gadapati, C.J., Kelly, K., While, C.L., Lyons, D.W., Wang, W., Gautam, M., and Bata, R.M., "Comparative Emissions from Natural Gas and Diesel Buses,” SAE Paper 952746, 1995.

27. Clark, N.N., Gautam, M., Rapp, B.L., Lyons, D.W., Graboski, M.S., McCormick, R.L., Alleman, T.L., and Norton, P., "Diesel and CNG Transit Bus Emissions Characterization by Two Chassis Dynamometer Laboratories: Results and Issues,” SAE Paper 1999-01-1469, 1999.

28. Norton, P., Vertin, K., Clark, N.N., Lyons, D.W., Gautam, M., Goguen, S., and Eberhardt, J., "Emissions from Buses with DDC 6V92 Engines Using Synthetic Diesel Fuel,” SAE Paper 1999-01-1512, 1999.

29. Clark, N.N., Lyons, D.W., Gautam, M., Atkinson, C., Xie, W., Norton, P., Vertin, K.,Goguen, S., and Eberhardt, J., "On-Road Use of Fischer-Tropsch Diesel Blends,” SAE Paper 1999-01-2251, 1999.

30. Clark, N.N., Boyce, J.E., Xie, W., Gautam, M., Lyons, D.W., Vertin, K., LeTavec, C.A., and Coburn, T.C., "Class 8 Trucks Operating on Ultra-Low Sulfur Diesel with Particulate Filter Systems: Regulated Emissions,” SAE Paper 200001-2815, 2000.

31. Chatterjee, S., McDonald, C., Conway, R., Windawi, H., Vertin, K., LeTavec, C.A., Clark, N.N., and Gautam, M., "Emission Reductions and Operational Experiences with Heavy-Duty Diesel Fleet Vehicles Retrofitted with Continuously Regenerated Diesel Particulate Filters in Southern California,” SAE Paper 2001-01-0512, 2001.

32. Chandler, K., Vertin, K., Alleman, T., Clark, N., "Ralphs Grocery Company ECDiesel $^{\mathrm{TM}}$ Truck Fleet - Final Results, DOE-NREL Truck Evaluation Project, Available at http://www.eere.energy.gov/afdc/pdfs/31363.pdf

33. Diesel Emission Control-Sulfur Effect (DECSE) Program - Summary of Reports, Produced by the National Renewable Energy Laboratory (NREL) for the U.S. Department of Energy (DOE). Also available at http://www.nrel.gov/vehiclesandfuels/apbf/pdfs/31600.pdf

34. Diesel Emission Control-Sulfur Effect (DECSE) Program - Final Report: Diesel Oxidation Catalysts and Lean NOx Catalysts, Produced by West Virginia University for the U.S. Department of Energy (DOE), Engine Manufacturers Association, and Manufacturers of Emissions Control Association, June 2001. Available at http://www.ott.doe.gov/decse

35. Tennant, C.J., deJong, R.D., Atkinson, R.J., Traver, M.L., Atkinson, C.A., Vincent, C.J., Clark, N.N., and Lyons, D.W., "Performance of a High Speed Engine with Dual Fuel Capability,” SAE Paper 940517, 1994.

36. MOTT, G.E., ATKINSON, C.M., CLARK, N.N. and ATKINSON, R.J., “Closed Loop Engine Control for Turbocharged Lean Burn Natural Gas Engine Operation,” ASME Internal Combustion Engine Division, 1995 Fall Technical Conference.

37. CLARK, N.N., ATKINSON, C.M., LYONS, D.W., MOTT, G.E., ATKINSON, R.J., De JONG, R.J., and LATVAKOSKI, T.E., “Closed Loop Fueling Control For A Lean Burn Natural Gas Engine,” Poster Presentation, Windsor Workshop on Alternative Fuels, Toronto, June 1996.

38. GAUTAM, M., LYONS, D.W., CLARK, N.N., WANG, W.G. and BERGIN, M., "In-use Particulate Matter Emissions from Heavy Vehicles," Annual Automotive 
Technology Customers’ Coordination Meeting, Dearborn, MI, Oct. 1997, Poster and Proceedings, Vol. III, pp. 559-562.

39. Park, T., Atkinson, R.J., Clark, N.N., Traver, M.L., and Atkinson, C.A., "Operation of a Compression Ignition Engine with a HEUI Injection System on Natural Gas with Diesel Pilot Injection,” SAE Paper 1999-01-3522, 1999.

40. Wayne, W.S., Corrigan, E.R., Atkinson, R.J., Clark, N.N., and Lyons, D.W., "Measuring Diesel Emissions with a Split Exhaust Configuration," SAE Paper 2001-01-1949, 2001.

41. NINE, R.D., CLARK, N.N., MACE, B.E. and EL-GAZZAR, L., "Hydrocarbon Speciation of a Lean Burn Spark Ignited Engine,” SAE Fuels \& Lubricants Conf., Tulsa, OK, October 1997, SAE Paper 972971.

42. Wu, Y., Clark, N., Carder, D., Thompson, G., Gautam, M., Lyons, D., "Parametric Study of 2007 Standard Heavy-Duty Diesel Engine Particulate Matter Sampling System,” SAE Paper 2007-01-0060, 2007. 